\title{
Patient Injury Incentives in Law
}

\author{
Bryan A. Liang ${ }^{\dagger}$
}

The managed care revolution has significantly changed the delivery and finance of healthcare in the United States. Previously, under the feefor-service regime, ${ }^{1}$ the alignment of incentives in the healthcare system encouraged the provision of care for patients: Patients could self-refer to primary care physicians or specialists without penalty; physicians were content to provide needed care (and more) in accordance with their professional ethic; and, because payers simply paid the bills, physicians had no financial incentive to leave any stone unturned in diagnosing and treating patients. Thus, physicians, as the primary decisionmakers, were arguably the appropriate parties to be held liable for patient injury. ${ }^{2}$

But now the United States has undergone a revolution that has overturned the traditional incentive structure in the delivery of healthcare; that revolution is managed care. Under managed care, a regime ruled by

$\dagger$ B.S., M.I.T., 1983; Ph.D., Harris School of Public Policy Studies, University of Chicago, 1989; M.D., Columbia University College of Physicians \& Surgeons, 1991; J.D., Harvard Law School, 1995. The comments and collective wisdom of Shannon M. Biggs and Professors Carol Chase, Doug Kmiec, and Shelley Saxer were invaluable. In the interest of full disclosure, I note that I and Harvey S. Frey, M.D., Ph.D., through the Health Administration Responsibility Project (on whose Board of Directors we both serve) co-drafted the ERISA section of H.R. 1415 with Representative Charles Norwood's office. Finally, I also thank Mr. Peter Gimino, Mr. Kurt Hartman, and Mr. Kris Storti for excellent research assistance and Mr. Bruce Barnett for editorial assistance.

This article was presented in part at Health and Risk: An International Symposium, 29 June$1 \mathrm{July}$ 1998, St. Catherine's College, Oxford University, and at Access to Healthcare in the Year 2000: 38th Annual Conference of the American College of Legal Medicine, 19-21 March 1998. I thank the members of these fora for their insightful comments and assistance.

1. Fee-for-service in this context represents payment by a third-party insurer based upon the fee established by the provider. Private insurers and government insurers, such as Medicare and Medicaid, simply paid the bills submitted by the provider. See PAUL STARR, THE SOCIAL TRANSFORMATION OF AMERICAN MEDICINE 385 (1982) (describing the economics of the feefor-service system).

2. See E. Haavi Morreim, Redefining Quality by Reassigning Responsibility, 20 AM. J.L. \& MED. 79, 80-84 (1994) (explaining the economic sources of physicians' right to define a standard of care); Allison Faber Walsh, The Legal Attack on Cost Containment Mechanisms: The Expansion of Liability for Physicians and Managed Care Organizations, 31 J. MARSHALL L. REV. 207, 209 (1997) (noting that physicians were "obviously" liable under this system); Elaine Lu, Recent Development, The Potential Effect of Managed Competition in Health Care on Provider Liability and Patient Autonomy, 30 HARV. J. ON LEGIS. 519, 532 (1993) (noting that courts historically have assumed it was impossible for anyone to control providers' medical decisions and, therefore, have held providers solely liable for the consequences). 
payers in a world of limited resources, things are no longer so luxurious. Patients, of course, continue to wish to be diagnosed and treated for their illnesses. In fact, since the patient-centered care movement has educated patients, demand for services is now even greater. ${ }^{3}$ In addition, as patients are typically older and live longer with multisystem diseases, ${ }^{4}$ the need for more intensive and complex medical evaluation and management increases. These developments, in addition to capital-intensive technological advances, have made these older patients more expensive to treat. ${ }^{5}$ However, while patients are demanding and requiring more care, escalating costs and declining resources have led payers to abandon the passive blank-check approach. ${ }^{6}$ The healthcare structure has thus been reversed so that the present incentives are to minimize care. From this pecuniary standpoint, the most valuable patient is the one never seen nor heard. Indeed, to implement cost containment, managed care organizations $(\mathrm{MCOs})^{7}$ - the primary healthcare payers of today ${ }^{8}$ - have signifi-

3. See Rebecca Walker, Governing Physician-Associated Risk Disclosure by Adopting the ADA "Direct Threat" Approach: Doctors, Pack up Your Stethoscopes and Get out Your Checkbooks, 1997 U. ILL. L. REV. 1199, 1202 (1997); cf. Judith F. Daar, Informed Consent: Defining Limits Through Therapeutic Parameters, 16 WHITTIER L. REV. 187, 194 (1995) (explaining that the patients' rights movement has focused on patients' medical needs); Marc A. Rodwin, Patient Accountability and Quality of Care: Lessons from Medical Consumerism and the Patients' Rights, Women's Health and Disability Rights Movements, 20 AM. J.L. \& MED. 147, 150-53 (1994) (describing the history of the patients' rights movement).

4. See, e.g., Robert N. Butler, Population Aging and Health, 315 BRrT. MED. J. 1082 (1997); William R. Hazzard, Ways to Make "Usual" and "Successful" Aging Synonymous: Preventive Gerontology, 167 W.J. MED. 206 (1997) (advocating a treatment method to reconcile increasing longevity with cost constraints); Patricia Etnyre-Zacher \& Jeanne M. Isabel, The Impact of an Aging Population on the Clinical Laboratory, MED. LABORATORY OBSERVER, Apr. 1997, at 48.

5. See Michael J. Malinowski, Capitation, Advances in Medical Technology, and the Advent of a New Era in Medical Terms, 22 AM. J.L. \& MED. 331, $341-42$ (1996) (noting increases in medical costs).

6. See Troyen A. Brennan, An Ethical Perspective on Health Care Insurance Reform, 19 AM. J.L. \& MED. 37, 39 (1993) (noting that payers have limited benefits); Malinowski, supra note 5, 335-36 (providing examples of limitations in benefits); Morreim, supra note 2, at 84-87 (explaining a variety of methods for cost control); Marc A. Rodwin, Strains in the Fiduciary Metaphor: Divided Physician Loyalties and Obligations in a Changing Health Care System, 21 AM. J.L. \& MED. 241, 253 (1995) (noting cost-control measures imposed by third-party payers); Faber Walsh, supra note 2, at 215-21 (noting various methods of cost control).

7. There are a plethora of forms in managed care. Classically, health maintenance organizations (HMOs) collect a fixed premium from enrollees for all necessary care. In exchange, the enrollees are limited to a selected provider panel, must go through a gatekeeper primary care physician for all services and referrals, and subject themselves to utilization review by the HMO to minimize costs. See PAtricia Younger et AL., Legal ANSWER BooK for MaNAgEd CARE 2 (1995). Several model forms of HMO exist: the staff model, where the HMO employs the physician providers; the group model, where the HMO contracts with a multispecialty group practice for all of its enrollees' needs; the network model, where the HMO contracts with more than one group practice to provide services to enrollees; the individual practice association (IPA) model, where the HMO contracts with an association of physicians to provide services to its enrollees; the direct contract model, where the HMO contracts directly with individual phy- 
cantly pressured physicians to minimize care and costs through legally binding financial and other contractual arrangements. ${ }^{9}$ MCOs have also limited patients from referring themselves to the physicians of their choice and specialty. ${ }^{10}$

The increasing patient demand for healthcare services and the change in payer behavior have substantially altered the role of the physician in healthcare delivery. Today, in contrast to the pre-revolution days under fee-for-service, the physician has severely conflicting incentives. On the one hand, he or she must still attempt to provide a level of healthcare consistent with his or her professional ethic and his or her legal liability for patient injury. ${ }^{11}$ On the other, he or she must limit care because legally legitimized payer incentives force physicians to minimize costs.

sicians; and the specialty model, where the HMO provides care only in a particular specialty area. See id. at 3-9. Another popular managed care form is the PPO, or Preferred Provider Organization. A PPO provides a network of physicians and other providers to employer health plans and health insurance carriers; a PPO provides coverage to enrollees like HMOs, but enrollees may opt to obtain care outside the PPO network, although their coverage for the costs of care will be lower. See id. at 9-10. Finally, an important type of MCO is the POS, or point-ofservice plan. A POS is a cross between an HMO and traditional fee-for-service indemnity. Enrollees choose whether to obtain care from providers within the HMO, with higher coverage, or another provider, with lower coverage. See id. at 12-13.

Generally, MCOs pay their physician contractors under two methods: capitation and discounted fee-for-service (in contrast with fee-for-service at levels set by physicians and other providers). Capitation is "[a] set amount of money received [by the physician] ...; it is based on membership [numbers] rather than on services delivered." THE MANAGED HEALTH CARE HANDBOOK 988 (Peter R. Kongstvedt ed., 3d ed. 1996). Thus, regardless of the services provided, the physician obtains the same remuneration; this payment structure provides the incentive for the provider to perform fewer services. HMOs commonly use capitation. As the name implies, discounted fee-for-service means that physicians and other providers are paid for the specific services they perform for enrollees at a discounted rate from their normal fees. See id. at 994; SHERYL TATAR DASCO \& ClIFFORD C. DASCO, MANAGED CARE ANSWER BOOK 12-14 (2d. ed. 1997). The incentive under discounted fee-for-service is to provide more services to the enrollee. Generally, PPOs use some form of discounted fee-for-service arrangement for provider remuneration and are not insurers because they do not bear risk.

8. In fact, in addition to these front-line payers, employers and the government also represent payers since they have a vested interest in minimizing costs. Thus these groups place pressure upon MCOs to minimize costs, and MCOs, in turn, pressure providers. See infra notes 2223 and accompanying text (discussing the role of the government and employers in the context of ERISA).

9. Beyond mere limitation on reimbursements, other methods of limiting costs include limitations on what kinds of care will be covered (e.g., exclusions of experimental treatments) and what kinds of care may be discussed by physicians (e.g., gag clauses). See infra Section II.B (discussing physician managed care contracting).

10. The standard $\mathrm{MCO}$ requires that patients obtain a primary care provider from a participating provider list. Generally, only after approval by the primary care physician may the patient receive a referral to a specialist; without this approval, the $M C O$ will not cover services rendered by the specialist. For a general discussion of the forms and structure of MCOs, see supra note 7.

11. See infra Sections II.A, II.C (discussing physician liability for patient injury in the managed care context). 
These shifts in the structure and function of medical care delivery have resulted in a very different sort of crisis in healthcare as compared to the malpractice crisis of the 1970 s and 1980 s. $^{12}$ The dominance of managed care in combination with the current legal infrastructure has created an incentive system at odds with both patient care and the physician's professional ethic of placing the patient first. As financial considerations overtake medical appropriateness as the primary concern in healthcare delivery, the risk of patient injury increases. ${ }^{13}$ Further, patients-who currently do not have means of redress against the MCOs because of the organizations' legal protections - cannot provide an incentive to health plans to shift the emphasis in health delivery from cost containment back to medical appropriateness. ${ }^{14}$ These developments have resulted in a backlash of legislation against MCOs; "patient protection" and "antimanaged care" proposals abound. ${ }^{15}$ However, none of these efforts addresses the heart of the problem-the incentives created by the current statutory and common law regime in the context of pressures from varying payers to reduce costs.

12. The medical malpractice crisis placed the medical care system into the general public consciousness for the first time in the 20 years since Medicare and Medicaid were established in 1965 and reforms began to arise. See generally U.S. GENERAL ACCOUNTING OFFICE, MEDICAL MALPRACTICE: A FRAMEWORK FOR ACTION, GAO/HRD-87-73 (1987); Donald N. Dewees et al., The Medical Malpractice Crisis: A Comparative Empirical Perspective, LAW \& CONTEMP. PROBS., Winter \& Spring 1991, at 217 (comparing responses in the United States and Canada); Mark F. Grady, Why Are People Negligent? Technology, Nondurable Precautions, and the Medical Malpractice Explosion, 82 Nw. U. L. REV. 293 (1988) (describing the role of technology in the development of malpractice claims); David J. Nye et al., The Causes of the Medical Malpractice Crisis: An Analysis of Claims Data and Insurance Company Finances, 76 GEO. L.J. 1495 (1988) (exploring the causes of increased malpractice insurance premiums); Glen $O$. Robinson, The Medical Malpractice Crisis of the 1970's: A Retrospective, LAW \& CONTEMP. PROBS., Spring 1986, at 5 (reviewing the events of the 1970s that caused and constituted the crisis); Joseph Sanders \& Craig Joyce, "Off to the Races": The 1980s Tort Crisis and the Law Reform Process, 27 Hous. L. REv. 207 (1990) (surveying the legislative tort reform efforts during the 1980s); S.Y. Tan, The Medical Malpractice Crisis: Will No-Fault Cure the Disease?, 9 U. HAW. L. REV. 241 (1987) (arguing that the no-fault approach to tort reform would be impractical); Comment, An Analysis of State Legislative Responses to the Medical Malpractice Crisis, 1975 DUKE L.J. 1417 (surveying various reforms passed in response to the crisis).

13. Cf. Michael Foster, Don't Sacrifice the Tort System on the Altar of Health Care Reform, 68 FLA. B. J., Dec. 1994, at 22 (arguing that malpractice suits do not improve access to or quality of care); Sylvia A. Law, A Consumer Perspective on Medical Malpractice, LAW \& CONTEMP. PROBS., Spring 1986, at 305 (arguing that malpractice does not improve the availability and quality of care); Leslie C. Giordani, Comment, $A$ Cost Containment Malpractice Defense: Implications for the Standard of Care for Indigent Patients, 26 Hous. L. REv. 1007 (1989) (arguing that malpractice suits fail to reduce cost-related injuries).

14. See infra Parts I-II (discussing ERISA and common law shields against MCO liability for patient injury).

15. See infra Part IV (discussing major proposals that attempt to address deleterious healthcare incentives). 
This Article will provide an overview of the common law of tort and contract and the statutory regime that have together created incentives for MCOs to minimize care while exposing physicians to, on the one hand, patient injury liability and, on the other, unfettered termination power in the hands of the MCO. The Article also criticizes current reform proposals that attempt to address the effects of managed care and proposes a comprehensive statutory solution that does address substantive difficulties. The proposal removes $\mathrm{MCO}$ incentives to limit care, relieves physicians from contradictory incentives, allows for implementation of a patient safety system, and provides redress for patients against all parties that participate in medical decisionmaking-MCOs as well as physicians.

Part I assesses the key statute relating to healthcare incentives, the Employee Retirement Income Security Act of 1974 (ERISA), ${ }^{16}$ as it relates to managed care. This Part concludes that the statute has created an extremely effective shield protecting MCOs against patient injury liability and has thereby reduced the healthcare system's incentives to provide necessary and adequate patient care. This Part also reviews cases that have pierced the MCO shield and finds that many of them are void because of jurisdictional errors made by the courts. Part II addresses the implications of the physician's usual status as an independent contractor to the MCO. This Part shows how common law tort rules of independent contractors provide MCOs with another successful shield against patient injury liability and how contract law solidifies the tort protection and allows the MCO strong control over the physician. Part III reviews the interacting incentives created by this legal infrastructure. This analysis shows a strong and clear incentive for MCOs to deny care to patients and mandate physicians to limit care. In contrast, because physicians do not possess the legal liability shields of MCOs, patients can back up their demands for maximum care with express or implied threats of litigation against the physician for injuries received. So, unlike the days of fee-forservice, physicians are confronted with severely conflicting incentives. Part III also demonstrates how, in addition to creating incentives that may increase risk for patient injury, the legal infrastructure prevents participation in innovative patient injury research and implementation that would reduce that risk. Part IV analyzes legislative proposals that attempt to address the prevailing incentives in the healthcare industry. On the state level, bills attempt to extend direct liability to MCOs for patient injury; on the federal level, some proposals would eliminate the MCO's ERISA shield against patient injury liability. However, upon analysis, the reforms at both levels prove to be piecemeal approaches that are unlikely

16. 29 U.S.C.A. $\$ \S 1001-1461$ (West $1985 \&$ Supp. 1998). 
to shift incentive structures to focus on patient care. Part $V$ proposes a federal statute that would align the incentives of payers and providers to refocus the health delivery system on patient care and addresses the potential increase in costs that the statute might cause. Finally, Part VI offers some concluding remarks.

\section{ERISA}

ERISA provides the basis for statutory protection of MCOs against patient injury suits. Through its history as applied to healthcare, there have been significant expansions of its scope, particularly its preemption of patient liability suits for denial of care. Courts have consistently held that ERISA preempts direct-liability suits against MCOs and have therefore presented very strong incentives for these health delivery organizations to deny care. ${ }^{17}$ There has been limited success in avoiding such summary preemption by claiming that the quality of care provided was poor rather than that care was denied ${ }^{18}$ however, these suits are premised upon some tenuous judicial reasoning and provide an even stronger incentive for MCOs to deny care. ${ }^{19}$ Furthermore, this limited success is not a victory for plaintiffs - they simply are allowed to have their cases heard in state court.

On the other hand, courts have not been nearly so consistent on the issue of whether indirect-liability suits against MCOs are preempted by ERISA, although a slim majority of decisions have held that they are not. ${ }^{20} \mathrm{~A}$ very substantial problem lies with many of the courts that have indicated that indirect suits are not preempted by ERISA: They may be asserting jurisdiction to hear these cases on faulty grounds, and thus their decisions may be void. ${ }^{21}$

\section{A. Context}

An MCO, whether a for-profit company, a mutual benefit company, or a non-profit entity, has an obligation to survive and serve its clientele in the most efficient way possible. In the intensely competitive market of healthcare delivery, the key to survival is minimizing costs. Private employers and government have a vested interest in MCOs minimizing costs since they finance most healthcare in the United States. As well, patients in their role as employees-who may have an expectation that healthcare is "free" as part of employment-have the incentive to advocate for

\footnotetext{
17. See infra Section I.C.

18. See infra Sections I.D-E.

19. See infra Sections I.F-G.

20. See infra Section I.H.

21. See infra Section I.I.
} 
minimal healthcare costs so their incomes will rise and their standard of living will increase. ${ }^{22}$

When an MCO delivers healthcare, its costs include not only fixed and predictable expenditures such as supplies, rent, and marketing materials but also the large, critical, and unpredictable cost associated with patient injury and resulting litigation. Thus, an MCO's efforts to minimize costs so as to survive in the healthcare market must necessarily focus on minimizing its patient injury costs. ERISA, as enacted by Congress and interpreted by the courts, has provided MCOs with a very effective legal strategy for minimizing their patient injury costs. ${ }^{23}$

\section{B. The ERISA Shield}

ERISA is a federal statute enacted in response to widely divergent state regulation of employee benefit plans (EBPs) ${ }^{24}$ Extensive, conflicting, and costly state regulation, and its perceived impact upon domestic industry's global competitiveness, spurred Congress to create a uniform federal regulatory structure for EBPs offered by employers engaged in interstate commerce. ${ }^{25}$ For this discussion, the most important EBPs are those that provide healthcare benefits: Employers collect premiums from, and purchase health benefits for, their employees and administer the benefits plans either themselves or through third-party administrators such as MCOs. ${ }^{26}$ ERISA EBPs are important because virtually all working persons are participants; ERISA regulates EBPs that cover approximately eighty-eight percent of private, nonelderly employees in the United States. ${ }^{27}$ Thus, the scope of ERISA's legal regulation and effect is enormous.

22. The employment-related fringe benefit of health insurance arose primarily from postWorld War II social conditions. See STARR, supra note 1, at 331-34 (describing the history of health benefits and the evolution of the use of private insurance to pay for healthcare).

23. The common law of tort and contract as it applies to independent contractor physicians provides a second effective legal strategy. See infra Part II.

24. See FMC Corp. v. Holliday, 498 U.S. 52, 56-60 (1990). An ERISA EBP is "any plan, fund, or program which [is] established or maintained by an employer ... for the purpose of providing for its participants or their beneficiaries, through the purchase of insurance or otherwise, (A) medical, surgical, or hospital care or benefits in the event of sickness, accident, disability, death ...."29 U.S.C. \$ 1002(1) (1994).

25. See 29 U.S.C. $\& 1003(\mathrm{a})(1)$ (1994); H.R. REP. No. 93-533, 93d Cong., reprinted in 1974 U.S.C.C.A.N. 4639, 4639-70.

26. See Mary A. Chirba-Martin \& Troyen A. Brennan, The Critical Role of ERISA in State Health Reform, 13 HEALTH AFF. 142 (1994). Since these plans are established or maintained by the employers rather than by an insurance company, they are also known as "self-insured" EBPs.

27. See Theodore Einhorn, Note, Reigning in ERISA Preemption? Any Willing Provider Statutes After New York Blue Cross Plans v. Travelers Insurance Co., 13 J. CoNTEMP. HeALTH L. \& POL'Y 265, 265 (1996). 
Two sections of ERISA play critical roles in any analysis of MCO liability and the incentives created thereby: section $514^{28}$ (the "preemption provision") and section $502^{29}$ (the "civil enforcement provision"). ERISA's preemption provision provides that the statute "shall supersede any and all State laws insofar as they may now or hereafter relate to any employee benefit plan. ${ }^{30}$ With these few words, Congress created one of the broadest preemption provisions it has ever passed. ${ }^{31}$ The statute provides that any and all state laws, i.e., statutory and common law ${ }^{32}$ as well as all other sources of state law, that "relate to" an ERISA EBP are preempted by the statute, regardless of whether the state laws are designed to affect EBPs ${ }^{33}$ or are consistent with ERISA itself. ${ }^{34}$ Thus, the statute itself provides all remedies for plan participants, who must forego statelaw tort and contract remedies.

Note, however, that this broad preemption ${ }^{36}$ does have an express exception: ERISA's "saving clause," part of section 514, provides that

28. 29 U.S.C.A. $\$ 1144$ (West 1985 \& Supp. 1998).

29. Id. \$1132.

30. 29 U.S.C. $\$ 1144$ (a) (1994).

31. See Ingersoll-Rand Co. v. McClendon, 498 U.S. 133, 138 (1990) ("Congress used th[e] words ["relate to" in the preemption provision] in their broad sense, rejecting more limited preemption language ...."); Pilot Life Ins. Co. v. Dedeaux, 481 U.S. 41, 45-46 (1987) (holding that ERISA's preemptive nature is "deliberately expansive"); accord Evans v. Safeco Life Ins. Co., 916 F.2d 1437, 1439 (9th Cir. 1990) ("ERISA contains one of the broadest preemption clauses ever enacted by Congress.").

32. See Pilot Life Ins. Co., 481 U.S. at 48 ("The common law causes of action [tortious breach of contract, breach of fiduciary duties, and fraud in the inducement] raised in [plaintiff's] complaint, each based on alleged improper processing of a claim for benefits under an employee benefit plan, undoubtedly meet the criteria for pre-emption ....").

33. See FMC Corp. v. Holliday, 498 U.S. 52, 58 (1990).

34. See, e.g., Tybout v. Karr Barth Pension Admin., 819 F. Supp. 371 (D. Del. 1993) (stating that a state law is preempted by ERISA, even if it is not specifically designed to affect an ERISA plan, has only an indirect effect, and is consistent with the statute).

35. See Pilot Life Ins. Co., 481 U.S. at 52 (holding, on the basis of the statute's text and legislative history, that ERISA $\$ 502$ (a) was intended by Congress to be the exclusive remedy for ERISA plan participants). The Court noted:

In sum, the detailed provisions of $\$ 502$ (a) set forth a comprehensive civil enforcement scheme that represents a careful balancing of the need for prompt and fair claims settlement procedures against the public interest in encouraging the formation of employee benefit plans. The policy choices reflected in the inclusion of certain remedies and the exclusion of others under the federal scheme would be completely undermined if ERISA-plan participants and beneficiaries were free to obtain remedies under state law that Congress rejected in ERISA. "The six carefully integrated civil enforcement provisions found in $\$ 502(a)$ of the statute as finally enacted ... provide strong evidence that Congress did not intend to authorize other remedies that it simply forgot to incorporate expressly."

Id. at 54 (quoting Massachusetts Mutual Life Ins. Co. v. Russell, 473 U.S. 134, 146 (1985)).

36. See Ingersoll-Rand Co., 498 U.S. at 137, 139. See also infra note 278 (discussing the evolution of ERISA preemption). Senator Williams, a sponsor of ERISA, indicated that: 


\section{Patient Injury Incentives}

"nothing in this subchapter shall be construed to exempt or relieve any person from any law of any State which regulates insurance, banking, or securities." ${ }^{37}$ However, although it would appear at first blush that an employer who arranges for and finances its employees' healthcare services is engaging in "the business of insurance," ERISA specifically indicates through its "deemer clause" that states may not deem EBPs as "engaged in the business of insurance":

Neither an employee benefit plan ... nor any trust established under such a plan[ shall be deemed to be an insurance company or other insurer, bank, trust company, or investment company or to be engaged in the business of insurance or banking for the purposes of any law of any state purporting to regulate insurance companies, insurance contracts, banks, trust companies, or investment companies. ${ }^{38}$

Thus, in combination, the saving and deemer clauses significantly limit states from regulating EBPs that provide healthcare benefits. In effect, these clauses allow employers to opt out of state regulations merely by setting up an ERISA EBP.

This result is important because it severely affects beneficiaries' access to state-law damage remedies; aggrieved beneficiaries who suffer injury from healthcare arranged through ERISA EBPs are limited to the remedies enumerated in the statute-generally, suits to recover the denied benefit or equitable relief. ${ }^{40}$ No punitive or extracontractual damages are allowed. ${ }^{41}$ This limitation brings into play the second important provision of ERISA: section 502, or the civil enforcement provision. Specifically, "[a] civil action may be brought ... by a participant or beneficiary [of an EBP] ... to recover benefits due him under the terms of his plan, to enforce his rights under the terms of the plan, or to clarify his rights to future benefits under the terms of the plan."

[i]t should be stressed that with the narrow exceptions specified in the bill, the substantive and enforcement provisions of the conference substitute are intended to preempt the field for Federal regulations, thus eliminating the threat of conflicting or inconsistent State and local regulation of employee benefit plans. This principle is intended to apply in its broadest sense to all actions of State or local governments, or any instrumentality thereof, which have the force or effect of law.

120 CONG. REC. 29,933 (1974).

37. 29 U.S.C. $\$ 1144$ (b)(2)(A) (1994).

38. Id. $\$ 1144(\mathrm{~b})(2)(\mathrm{B})$.

39. See Metropolitan Life Ins. Co. v. Massachusetts, 471 U.S. 724, 747 (1985).

40. Equitable relief does not include any compensatory, consequential, or punitive monetary damages. See Varity Corp. v. Howe, 516 U.S. 489, 510-15 (1996); Mertens v. Hewitt Assocs., 508 U.S. 248, 255 (1993).

41. See Massachusetts Mut. Life Ins. v. Russell, 473 U.S. 134 (1985); Drinkwater v. Metropolitan Life Ins. Co., 846 F.2d 821, 825 (1st Cir. 1988); Sokol v. Bernstein, 803 F.2d 532, 534-38 (9th Cir. 1986); Powell v. Chesapeake \& Potomac Tel. Co., 780 F.2d 419, 424 (4th Cir. 1985).

42. 29 U.S.C. $\$ 1132(a)(1)(B)$ (1994). Note that patients may seek care first and then seek 
for wrongful death, personal injury, or other claims for consequential damages caused by an insurer's or utilization reviewer's improper refusal of care or coverage are preempted because they pray for relief not enumerated in the section. ${ }^{43}$ Indeed, if the patient/employee dies as a result of an inappropriate or negligent denial of care, the decedent will be entitled to nothing, since recovery of the benefit of "treatment coverage is no longer of any significance. ${ }^{, 44}$ Finally, ERISA does not allow for jury trials in these civil enforcement adjudications. ${ }^{45}$

As might be expected, this federal effort to limit state regulation of EBPs has resulted in an extremely large majority of employers providing

recovery from the plan. See, e.g., Hermann Hosp. v. MEBA Med. \& Benefits Plan, 845 F.2d 1286 (5th Cir. 1988) (holding that a hospital that was assigned benefits due an ERISA plan beneficiary could sue the plan under $\$ 502$ when the plan refused to pay). However, the costs of such care may make this alternative prohibitive.

43. See 29 U.S.C. $\$ 1132$ (a)(1)(B), (a)(3) (1994). Note that, through the civil enforcement provision, ERISA does authorize a plan participant or beneficiary to obtain "appropriate" equitable relief for the breach of the fiduciary duty established under 29 U.S.C. \& 1109(a). See id. \& 1132(a)(1). However, any extracontractual damages recovered pursuant to these provisions inure to the plan itself, not the individual beneficiary. See Massachusetts Mut. Life Ins. Co., 473 U.S. at $140-44$.

44. Turner v. Fallon Community Health Plan, 127 F.3d 196, 198 (1st Cir. 1997).

45. See Chilton v. Savannah Foods \& Indus., 814 F.2d 620, 623 (11th Cir. 1987); Turner v. CF \& I Steel Corp., 770 F.2d 43, $46-47$ (3d Cir. 1985); Katsaros v. Cody, 744 F.2d 270, 278 (2d Cir. 1984); In re Vorpahl, 695 F.2d 318, 322 (8th Cir. 1982); Calamia v. Spivey, 632 F.2d 1235, 1237 (5th Cir. 1980); Wardle v. Central States, Southeast and Southwest Areas Pension Fund, 627 F.2d 820, 821 (7th Cir. 1980). Further, a denial of ERISA benefits is reviewed de novo by the courts unless the EBP gives the plan administrator discretionary authority to determine the eligibility for benefits or the terms of the plan. In the latter case, the standard for review is simply abuse of discretion with the burden of proof upon the plaintiff. See Firestone Tire \& Rubber v. Bruch, 489 U.S. 101, 115 (1989). Most plans do give the administrator discretion; thus, the most commonly applied standard is abuse of discretion, which has been articulated as examining whether the plan administrator acted arbitrarily or capriciously in denying an EBP benefit. See Bellaire Gen. Hosp. v. Blue Cross Blue Shield, 97 F.3d 822, 828-29 (5th Cir. 1996). Note, however, that when the entity with discretion both administers and is the insurer of the EBP, courts have departed from the simple abuse of discretion standard. See, e.g., Armstrong v. Aetna Life Ins. Co., 128 F.3d 1263, 1265 (8th Cir. 1997) (adopting a de novo standard of review); Chambers v. Family Health Plan Corp., 100 F.3d 818, 824-27 (10th Cir. 1996) (adopting a "sliding scale" approach where the court applies an abuse of discretion standard but reduces the amount of discretion in proportion to the seriousness of the issue); Doe v. Group Hospitalization \& Med. Serv., 3 F.3d 80, 87 (4th Cir. 1993) (same); Wildbur v. ARCO Chem. Co., 974 F.2d 631, 638-42 (5th Cir. 1992) (same); Van Boxel v. Journal Co. Employees' Pension Trust, 836 F.2d 1048, 1052-53 (7th Cir. 1987) (same); Atwood v. Newmont Gold Co., 45 F.3d 1317, 1323 (9th Cir. 1995) (citing GEORGE T. BOGERT, TRUSTS § 95 (6th ed. 1987), and adopting a "presumptively void" test where the decision of the plan administrator is presumed to be an abuse of discretion unless the administrator can show under de novo review that the action was correct or that the decision was not made to serve the administrator's interest); Brown v. Blue Cross \& Blue Shield, 898 F.2d 1556, 1566-67 (11th Cir. 1990) (citing BOGERT \& BOGERT, THE LAW OF TRUSTS \& TRUSTEES $\$ 543$, at 40-42 (rev. 2d ed. Supp. 1989) and adopting a rule that, where a beneficiary proves a conflict of interest on the part of the administrator in a benefits determination, the administrator must demonstrate that a determination against the beneficiary was made not on the basis of self-interest but rather in the interest of the class of all beneficiaries). 
healthcare benefits to their employees as part of their benefits plans ${ }^{46}$ while simultaneously keeping healthcare costs under some semblance of control. ${ }^{47}$ However, it has also insulated MCOs that provide care and services to ERISA plan beneficiaries from any responsibility for patient injury, because "the practical impact of ERISA ... is to immunize [insurers and MCOs] from any potential liability for the consequences of their denial of benefits."

\section{The Direct MCO Liability Shield: Quantity, not Quality}

How does ERISA insulate MCOs from patient injury liability? The cases discussed below in this Section suggest a typical pattern: If an employee is injured through a healthcare decision of an ERISA MCO, he or she will attempt to bring a medical malpractice or other negligence action in state court against the particular MCO. The patient will, for example, claim that the MCO had a duty to provide him or her with an acceptable level of medical care, that the MCO breached that duty, and that the breach caused his or her injury. However, because the MCO provides services through an ERISA EBP, the MCO will attempt to remove the case from state court to federal court. ${ }^{49}$ The federal court then decides whether the claim will stand or be preempted by the statute.

Federal courts of appeals that have addressed the issue of direct statelaw causes of action alleging MCO liability for the denial or withholding of benefits ${ }^{50}$ have found that such causes of action are preempted under both the civil enforcement provision and the preemption provision of

46. More than two-thirds of U.S. employers form ERISA plans, representing approximately half of the U.S. workforce. See Troy Paredes, Stop-Loss Insurance, State Regulation, and ERISA: Defining the Scope of Federal Preemption, 34 HARV. J. ON LEGIS. 233, 234 (1997). Indeed in 1992 almost $90 \%$ of Fortune 500 companies funded these plans. See id. at 235 . And approximately 190 million people receive their healthcare through some form of managed care. See Bryan A. Liang, Deselection Under Harper v. Healthsource: A Blow for Maintaining Patient-Physician Relationships in the Era of Managed Care?, 72 NOTRE DAME L. REV. 799, 799 n.1 (1997) [hereinafter Liang, Deselection] (citing Mary Jane Fisher, Health Care Reform Battles Shifting to States, NAT'L UNDERWRITER \& PROP. \& CASUALTY-RISK \& BENEFITS MGMT., July 31, 1995, at 9).

47. See, e.g., Dennis A. Yao, The Analysis of Hospital Mergers and Joint Ventures: What May Change?, 1995 UTAH L. REV. 381, 382 (1995); EBRI Predicts Increased Movement Toward Plans Due to Rising Costs, 2 Health Care Pol'y Rep. (BNA) 44 (Nov. 7, 1994); Health Spending Hit Record Law in 1996 Due in Part to Managed Care, Study Finds, 4 Managed Care Rep. (BNA) 65 (Jan. 21, 1998); Surge in Managed Care Enrollment Held Cost Hikes Low in 1997, Survey Finds, 4 Managed Care Rep. (BNA) 88 (Jan. 28, 1998).

48. Andrews-Clarke v. Travelers Ins. Co., 984 F. Supp. 49, 55-56 (D. Mass. 1997).

49. See Metropolitan Life Ins. Co. v. Taylor, 481 U.S. 58, 61 (1987) (noting that the MCO's claimed basis for removing the case to federal court was that the plaintiff's cause of action was completely preempted under ERISA and thus should be dismissed under the complete preemption doctrine).

50. Examples of such state-law causes of action include: medical malpractice, wrongful death, misrepresentation, intentional and negligent infliction of emotional distress, bad faith, and negligence in plan administration. 
ERISA. These holdings have been consistent even after the Supreme Court's recent "abrupt" rejection of a formalist interpretation of ERISA and its preemptive scope in New York Conference of Blue Cross \& Blue Shield Plans v. Travelers Insurance Co ${ }^{51}$ For example, in a post-Travelers case, ${ }^{52}$ Turner v. Fallon Community Health Plan, ${ }^{53}$ the plaintiff sued in state court to recover on several state-law claims including breach of contract and wrongful death against an ERISA MCO. Turner and his wife were members of an ERISA EBP and received their healthcare through an ERISA healthcare plan. She contracted breast cancer and, after several attempts to secure authorization for an autologous bone marrow transplant, was denied coverage and subsequently died. ${ }^{54}$ Turner then sued and the MCO removed the case to federal district court, which granted summary judgment to the MCO. ${ }^{55}$ Turner appealed, and the First Circuit affirmed. The court indicated that Turner "seeks damages ... and his grievance-a denial of benefits-is specifically addressed by [ERISA's civil enforcement provision]. ${ }^{, 56}$ Since his state-law claims were

51. 514 U.S. 645 (1995). See also infra note 278 (discussing the change in the Supreme Court's interpretation of the scope of ERISA preemption from "expansive" to that which should be made effective only if the state law is beyond an "indirect source of merely economic influence on administrative decisions....", Travelers Ins. Co., 514 U.S. at 662). For discussion of this change by courts, see De Buono v. NYSA-ILA Medical \& Clinical Services Fund, $117 \mathrm{~S}$. Ct. 1747, 1752-53 (1997); and California Division of Labor Standards Enforcement v. Dillingham Construction, N.A., 117 S. Ct. 832, 842 (1997).

52. Federal district courts have also adhered to these interpretations pre- and postTravelers. See, e.g., Andrews-Clarke v. Travelers Ins. Co., 984 F. Supp. 49, 53-55 (D. Mass. 1997) (holding that state-law claims for denial of mental health benefits by an ERISA provider and a utilization review company were preempted by ERISA); Schmid v. Kaiser Foundation Health Plan, 963 F. Supp. 942, 944-45 (D. Or. 1997) (finding that state-law claims for breach of contract and negligence brought directly against an MCO were preempted by ERISA); Lancaster v. Kaiser Foundation Health Plan, 958 F. Supp. 1137, 1149-50 (E.D. Va. 1997) (stating that ERISA preempts direct negligence and fraud claims against an HMO); Kearney v. U.S. Healthcare, 859 F. Supp. 182, 184-85 (E.D. Pa. 1994) (stating that direct-liability claims against an MCO for wrongful death, misrepresentation, and breach of contract were preempted by ERISA); Elsesser v. Hospital of the Philadelphia College of Osteopathic Medicine, Parkview Div., 802 F. Supp. 1286, 1292 (E.D. Pa. 1992) (finding that claims seeking to hold an HMO directly liable for refusing to pay for Halter monitoring equipment under EBP, for misrepresentation, and for breach of contract were preempted by ERISA); Kohn v. Delaware Valley HMO, No. 91-2745 CIV A, 1991 WL 275609 at $* 4-5$ (E.D. Pa. Dec. 19, 1991) (finding that state-law claims against an HMO in an ERISA plan resulting from a failure to provide promised benefits and a discouragement of referrals were preempted by ERISA); Altieri v. CIGNA Dental Health, 753 F. Supp. 61, 63-65 (D. Conn. 1990) (holding that ERISA preempts both claims that an $\mathrm{MCO}$ was negligent in determining a provider's competence and claims that the MCO misrepresented the quality of benefits offered); see also In re Estate of Frappier, 678 So. 2d 884, 885 (Fla. Dist. Ct. App. 1996) (stating that direct corporate liability and implied contract claims were both preempted by ERISA).

53. 127 F.3d 196 (1st Cir. 1997).

54. Although the contract for health services explicitly excluded bone marrow transplants, the plan afforded plaintiff the opportunity to obtain such services if there was a "strong likelihood of success." Id. at 197. However, the plan concluded that no treatment center would afford such a likelihood and denied the request. See id.

55. See Turner v. Fallon Community Health Plan, 953 F. Supp. 419, 425 (D. Mass. 1997).

56. Turner, 127 F.3d at 200. 


\section{Patient Injury Incentives}

for compensatory and consequential damages rather than recovery of the benefits due under the terms of the plan or clarification or enforcement of rights under the terms of the plan, his claims were preempted under the civil enforcement provision. ${ }^{57}$ The court also seemed to invoke ERISA's preemption provision and, in doing so, distinguished cases from the Travelers line:

[Those cases did not] involve[ a state's attempt to provide state remedies for what is in essence a plan administrator's refusal to pay allegedly promised benefits. It would be difficult to think of a state law claim that "relates" more closely to an employee benefit plan than one that affords remedies for the breach of obligations under that plan.

The court then dismissed the suit. ${ }^{59}$

Similarly, in Tolton v. American Biodyne, ${ }^{60}$ the Sixth Circuit Court of Appeals rejected Tolton's direct state-law claims against the ERISA MCO for wrongful death, improper refusal to authorize benefits, medical malpractice, insurance bad faith, breach of contract, negligent retention of healthcare services by the $\mathrm{MCO}$, and loss of consortium as preempted by ERISA. ${ }^{61}$ In this case, Tolton's husband was an ERISA beneficiary enrolled in an ERISA EBP that provided healthcare benefits. The beneficiary was severely addicted to crack cocaine and attempted to obtain mental health services to free himself of the addiction. He was seen by mental health providers under contract with his ERISA MCO. Although he had some complaints about the providers' approach to addiction treatment, ${ }^{62}$ he continued to access these providers for his mental health treatment. At the time in question, the beneficiary began to have suicidal thoughts; he called his mental health providers but hung up before he was connected to a therapist. He then called his $\mathrm{MCO}$ and expressed suicidal thoughts; in response, one of his psychologists called him back, at which point he indicated he was not suicidal. However, he requested inpatient care rather than the out-patient appointment that was proffered; this request was not authorized. After the request for in-patient treatment, he was seen in a local emergency room for suicidal thoughts as well as for violent actions and thoughts; he was subsequently admitted to a mental health crisis center for treatment. After discharge and another cycle of suicidal ideation, emergency room visit, and discharge to a mental

57. See id. at 198.

58. Id. at 199. See also Johnson v. Dist. 2 Marine Eng'rs Beneficial Ass'n, 857 F.2d 514 (9th Cir. 1988) (finding that state-law claims against a plan for the plan's decision to deny a liver transplant to a beneficiary were preempted by ERISA).

59. See Turner, 127 F.3d at 200.

60. 48 F.3d 937 (6th Cir. 1995).

61. See id. at 944 .

62. The mental health providers would "challenge" the addicted patient to stay drug free for a certain number of days without medical intervention. See id. at 940 . 
health center, he established a relationship with a psychiatrist and agreed not to commit suicide before speaking with the therapist. For approximately two weeks, he saw a psychiatrist daily; after this period he was referred to another treatment program. Unfortunately, after six days at the program, he committed suicide. ${ }^{63}$

Tolton, in her own capacity and representing her spouse, brought suit in state court against the $\mathrm{MCO}$, among others, claiming contract and tort law causes of action. ${ }^{64}$ As expected, the MCO removed to federal court, where the district judge granted summary judgment for the defendant. ${ }^{65}$ Tolton appealed and, as in the First Circuit, the court of appeals affirmed. ${ }^{66}$ The Sixth Circuit held that the "plaintiff's claims ... from an allegedly improper denial of benefits to an ERISA beneficiary fall squarely within [ERISA's civil enforcement provision]" and thus were properly held to be preempted. ${ }^{67}$

[T] he Supreme Court held that "Congress clearly expressed an intent that the civil enforcement provisions of ERISA $\$ 502$ (a) be the exclusive vehicle for actions by ERISA-plan participants and beneficiaries asserting improper processing of a claim for benefits, and that varying state causes of action for claims within the scope of $\$ 502$ (a) would pose an obstacle to the purposes and objectives of Congress..." Utilization review[-based claims are preempted because utilization review] is a means of processing claims, and, therefore, falls within the scope of $\S 502(\mathrm{a}) .^{68}$

Like the First Circuit in Turner, the Tolton court invoked ERISA's preemption provision:

[A]ll [plaintiff's claims] arise from [defendant's] refusal to authorize psychiatric benefits to [plaintiff's spouse] under the plan. Plaintiff's claims against these defendants, therefore, clearly "relate to" the benefit plan....

[Defendant] and its employees were determining what benefits were available to [plaintiff's spouse] under the plan....

$\ldots$

Plaintiff's claims against [defendant], therefore, are preempted [under ERISA's preemption provision].
63. See id.
64. See id.
65. See Tolton v. American Biodyne, 854 F. Supp. 505, 511 (N.D. Ohio 1993).
66. See Tolton, 48 F.3d at 939.
67. Id. at 941.
68. Id. at 942 (quoting Pilot Life Ins. Co. v. Dedeaux, 481 U.S. 41, 52 (1987)).
69. Id. at 942-43 (citations omitted); cf. Powell v. Chesapeake and Potomac Tel. Co., 780 F.2d 419 (4th Cir. 1985) (finding that a beneficiary's state-law claim for breach of fiduciary du- 
The court then dismissed all of Turner's claims against the MCO and its providers. $^{70}$

Beyond direct-liability claims for benefit denials, state-law causes of action based on patient injury due to a withdrawal of initially approved treatment by an MCO are also preempted under ERISA. In Spain $v$. Aetna Life Insurance Co. ${ }^{71}$ the Ninth Circuit Court of Appeals held that a wrongful death suit on the basis of negligent administration of an ERISA beneficiary's claim for benefits was preempted by ERISA. The plaintiffs, the wife and daughter of the deceased, brought an action in federal district court against the MCO after the ERISA EBP beneficiary died of testicular cancer. ${ }^{72}$ The MCO, which had approved a three-part bone marrow transplant procedure for the decedent after he was diagnosed, later withdrew its authorization, contending that the decedent's condition did not make him eligible for the procedure. After the MCO withdrew the authorization, the beneficiary gave notice that he intended to sue to compel reauthorization of the treatment. Two days after this notice, the MCO reauthorized the procedure. However, even after obtaining the requested treatment, the patient died. The Spains brought suit against the MCO on the basis that the patient's death was caused by the MCO's negligent withdrawal of authorization for treatment. The district court dismissed their claims, ${ }^{73}$ and they appealed. The court of appeals first noted that "[a]lthough [plaintiffs] do not seek benefits under the plan, their state common law cause of action seeks damages for the negligent administration of benefit claims. ${ }^{, 74}$ The court then dismissed plaintiffs' suit, relying heavily on ERISA's preemption provision:

This circuit, following the lead of the Supreme Court in Pilot Life Ins. Co. v. Dedeaux, has held that "state common law causes of action arising from the improper processing of a claim are preempted by federal law." Hence, ERISA preempts [plaintiffs'] wrongful death action because the state law in its application directly "relates to" the administration and disbursement of ERISA plan benefits.

In addition, the court used ERISA's civil enforcement provision to support its holding.

\footnotetext{
ties in handling her disability benefits was preempted by ERISA).

70. See Tolton, 48 F.3d at 944.

71. 11 F.3d 129 (9th Cir. 1993).

72. See id. at 131.

73. See id. (noting dismissal on grounds that ERISA preempted the plaintiff's state-law claim).

74. Id.

75. Id. (citing Pilot Life Ins. Co. v. Dedeaux, 481 U.S. 41, $45-46$ (1987)) (quoting Kanne v. Connecticut Gen. Life Ins. Co., 867 F.2d 489, 493 (9th Cir. 1988)).
} 
Congress carefully constructed the civil enforcement provisions allowed under ERISA. As the [Supreme] Court instructed, "[t] flected in the inclusion of certain remedies and the exclusion of others [such as wrongful death tort claims] under the federal scheme would be completely undermined if ERISA-plan participants and beneficiaries were free to obtain remedies under state law that Congress rejected in ERISA."

The court also noted that a saving clause analysis would not preserve the Spains' cause of action:

[A] state wrongful death claim is not "saved" by the sole exception to ERISA's preemption rule. Although the ERISA preemption clause is broad, Congress created an exception for "any law of any State which regulates insurance, banking, or securities." Under this exception, a law must not just have an impact on an insurance company, "but must be specifically directed toward that industry." The cause of action for wrongful death at issue in this appeal is a general tort and clearly was not specifically tailored by the state to regulate insurance, banking, or securities."

Thus, the court held not only that state-law claims were preempted by ERISA's preemption and civil enforcement provisions but also that a saving clause analysis would provide no recourse to the Spains.

Furthermore, claims based on delays for treatment authorizations even longer than those imposed on Spain and that ultimately make the medically prescribed treatment untenable are also preempted under a denial-of-benefits analysis. In Kuhl v. Lincoln National Health Plan, ${ }^{78}$ the plaintiffs (Kuhl in her own capacity and representing her spouse, an ERISA EBP participant) sued the MCO after the ERISA EBP participant died. After he had suffered a heart attack, initial diagnosis and treatment revealed that significant cardiac problems remained which necessitated aggressive surgical intervention. ${ }^{79}$ After two separate assessments, the evaluating physicians decided that it was in the best interest of the patient to obtain these interventions at an out-of-state academic medical center specializing in such treatment. A cardiac surgeon at that center was consulted and agreed to perform the procedures. However, because the academic center was outside of the MCO treatment area, a utilization review coordinator refused to authorize the procedure and its concomitant payment. As a result, the surgery was canceled. After cancellation, another consultation was made to a cardiac surgeon within the MCO treatment area, who immediately indicated that the best course of

76. Id. at 132 (citation omitted) (quoting Pilot Life Ins. Co., 481 U.S. at 54).

77. Id. (citations omitted) (quoting Pilot Life Ins. Co., 481 U.S. at 50).

78. 999 F.2d 298 (8th Cir. 1993).

79. The participant apparently had significant damage to his heart, which resulted in inducible ventricular tachycardia, in turn requiring open heart aneurysmectomy and a coronary by-pass procedure. See $i d$. at 300 . 
treatment would be for the participant to have his surgery performed at the academic medical center. Thus, two weeks after this evaluation and a month after its initial pre-certification refusal, the $\mathrm{MCO}$ authorized the surgery. ${ }^{80}$ Because of the original cancellation, however, the academic medical center surgical team was not available until three months later to perform the specific procedures needed by the patient. The surgery was scheduled for that time, but, when the cardiac surgeon evaluated the participant at the newly scheduled time, it was apparent that the participant's heart had deteriorated to such an extent that surgery was no longer a viable option. Instead, only a heart transplant would be efficacious. ${ }^{81}$ The MCO refused to preauthorize payment for these treatment costs; however, the participant was placed on a waiting list for a heart transplant at a local medical center. While still on the list three months later, the patient died of ventricular tachycardia, the very condition that induced his first cardiac referral. ${ }^{82}$ The Kuhls sued the MCO in state court for medical malpractice, emotional distress, tortious interference with the husband's right to contract for medical care, and breach of contract; the $\mathrm{MCO}$ as a matter of course removed to federal district court. ${ }^{83}$ The district court granted the MCO's motion for summary judgment, and the plaintiffs appealed. ${ }^{\$ 4}$

The Eighth Circuit Court of Appeals affirmed..$^{85}$ The court indicated first that the Kuhls' state-law claims were clearly preempted by ERISA: "We have no difficulty in concluding that the [plaintiffs'] ... state law claims ... rely on [participant's] status as a beneficiary of the [EBP] [and] are preempted by ERISA." "\$6 The court noted that the Kuhls' attempt to reconstitute their claims as "cancellation" of the procedures by the MCO and malpractice of the ERISA administrator were to no avail.

Artful pleading by characterizing [the MCO's] actions in refusing to pay for the surgery as 'cancellation' or by characterizing the same administrative decisions as 'malpractice' does not change the fact that plaintiffs' claims are based on the contention that [the MCO] improperly processed [participant's] claims for medical benefits.

... Although the surgery [outside the plan area] was unquestionably cancelled as a result of [the MCO's] decision not to precertify payment, the deci-
80. See id.
81. See id.
82. See id.
83. See id.
84. See id. at 301.
85. See id. at 305.
86. Id. at 302 . 
sion not to precertify payment relates directly to [the MCO's] administration of benefits.

The court then affirmed the district court's judgment. ${ }^{88}$

The ERISA MCO direct-liability shield extends still further. Statelaw claims based upon allegations of wrongful revocation of EBP health plan insurance are also preempted. In Settles v. Golden Rule Insurance Co. ${ }^{89}$ the plaintiff brought an action in federal district court on the basis of diversity of citizenship after her husband, an ERISA beneficiary, died. Settles's spouse obtained health insurance benefits through his employer, who contracted with an insurance carrier to administer the health plan. At the time in question, a representative of the insurance carrier indicated to Settles's spouse that he was no longer covered by the health insurance plan. Five days later, he was told by an agent of the plan that he indeed was covered. Yet two days after that affirmation, he was notified that the insurance carrier had unilaterally terminated his coverage retroactive to seventeen days prior to his notice. On the day he received that last notification, he suffered a heart attack; five days later he passed away. Settles instituted her action claiming that "as a direct consequence of [the carrier's] actions in terminating her husband's health insurance, he became severely depressed and suffered a heart attack." ${ }^{\circ 0}$ She brought a direct-liability suit against the MCO for breach of contract, the tort of outrage, fraudulent denial of insurance coverage, and wrongful death.

The district court granted summary judgment for the defendant, ${ }^{91}$ and Settles appealed. ${ }^{92}$ The Tenth Circuit Court of Appeals affirmed. The court noted that for state-law claims to pierce the ERISA preemption shield, the claims must be "wholly remote" from the EBP..$^{93}$ In this case,

$[t]$ he injury alleged was a direct result of the termination of plan benefits and cannot be characterized as "wholly remote" from the benefit plan.

The factual basis for each of plaintiff's state law claims directly concerns the alleged improper administration of the benefit plan.... [H]er claims require a finding that defendant wrongfully terminated [her spouse's] insurance coverage. Therefore, the claims relate to the employee benefit plan....We

87. Id. at 303 (quoting Kuhl v. Lincoln Nat'l Health Plan, No. 91-0330-CV-W-9, 1991 WL 523899, at *17 (W.D. Mo. Dec. 26, 1991)); see also Murphy v. Wal-Mart Assocs. Group Health Plan, 882 F. Supp. 95 (E.D. Tex. 1995) (finding that a state-law claim against providers for an inappropriate assessment of the medical necessity for lymphoma treatment was preempted by ERISA).

88. See Kuhl, 999 F.2d at 305.

89. 927 F.2d 505 (10th Cir. 1991).

90. Id. at 507 .

91. See Settles v. Golden Rule Ins. Co., 715 F. Supp. 1021, 1023 (D. Kan. 1989).

92. See Settles, 927 F.2d at 507.

93. See id. at 509 (quoting Clark v. Coats \& Clark, 865 F.2d 1237, 1243-44 (11th Cir. 1989)). 
hold that, because plaintiff's claims "relate to" an employee benefit plan covered by ERISA, they are preempted by ERISA."

Indeed, the court also noted that:

The Supreme Court in Pilot Life held that \$1132(a) [the statute's civil enforcement provision] is "the exclusive vehicle for action by ERISA-plan participants and beneficiaries asserting improper processing of a claim for benefits, and that varying state causes of action for claims within the scope of [the civil enforcement provision] would pose an obstacle to the purposes and objectives of Congress [and are hence preempted]. ${ }^{95}$

Thus, the court, consistent with other courts of appeals, utilized ERISA's civil enforcement provision and the preemption provision to hold that Settles's state-law claims were preempted. In dicta, the court also noted that Settles could not rely on ERISA's equitable remedy power to bar preemption.

Plaintiff also argues that because [ERISA] authorizes the courts to use "other appropriate equitable relief" to redress ERISA violations, the court should allow state wrongful death claims as a form of equitable relief. Plaintiff's reading of [these provisions] is not persuasive. Giving courts flexibility in granting relief should not be confused with giving courts power to evade the broad preemption provision enacted by Congress... [and] cannot be read as permitting plaintiff's wrongful death claim. ${ }^{96}$

Finally, in Corcoran v. United HealthCare, ${ }^{97}$ the Fifth Circuit Court of Appeals rejected state-law tort claims for wrongful death, loss of consortium, and emotional distress directed against an MCO's utilization reviewer. The Corcorans brought suit against United HealthCare, a utilization review company that determined the relative level of healthcare benefits available to the Corcorans under their ERISA EBP. Mrs. Corcoran became pregnant; because a previous medical history made her pregnancy high-risk, her obstetrician strongly recommended that she be admitted for extended hospitalization to allow continuous fetal monitoring until delivery. ${ }^{98}$ United HealthCare refused to authorize the hospitalization, however, and instead approved only ten hours per day of home nursing. ${ }^{99}$ Tragically, during a period of time when no nurse was at the Corcorans' home, the fetus went into distress and subsequently died. ${ }^{100}$

The Corcorans filed their state-law claims in state court and the defendant successfully removed the case to federal district court on the ba-

94. Id. (citations omitted).

95. Id. at 510 (quoting Pilot Life Ins. Co. v. Dedeaux, 481 U.S. 41, 52 (1987)).

96. Id. (quoting 29 U.S.C. $\$ 1132(\mathrm{a})(3)$ ).

97. 965 F.2d 1321 (5th Cir. 1992).

98. See id. at 1322.

99. See id. at 1324 .

100. See id. 
sis of ERISA and complete diversity between the parties. ${ }^{101}$ United HealthCare moved for summary judgment on the basis of ERISA preemption; the district court granted the motion ${ }^{102}$ and the Corcorans appealed. ${ }^{103}$ The Fifth Circuit Court of Appeals affirmed. ${ }^{104}$ The court agreed with the Corcorans that the utilization review company was engaged in medical decisionmaking but still held against them.

Ultimately, we conclude that [the utilization review company] makes medical decisions-indeed, [it] gives medical advice-but it does so in the context of making a determination about the availability of benefits under the plan. Accordingly, we hold that the ... tort action asserted by the Corcorans for the wrongful death of their child allegedly resulting from [the company's] erroneous medical decision is preempted by ERISA. ${ }^{105}$

The Corcorans argued that medical decisionmaking should not be preempted because its regulation had long been a state function. The court answered:

ERISA's pre-emption section itself contains an explicit exemption for state laws that regulate in at least one area of traditional state functioninsurance. ERISA $\S 514(\mathrm{~b})(2)(\mathrm{A})$. There is no reason to believe that Congress intended implicitly to exempt a whole range of state laws when it showed itself perfectly capable of carving out specific exceptions. ${ }^{106}$

Even though the court recognized that the Corcorans would be left with no remedy for the utilization review company's actions under state or federal law, the state-law claims could not stand due to the sweeping preemptive effects of ERISA. ${ }^{107}$ The court also noted that the Corcorans

101. The court of appeals misconstrued the difference between conflict preemption and complete preemption in assessing its jurisdiction in the case. Although the court did have jurisdiction on the basis of diversity and the fact that plaintiffs claimed damages for emotional distress under ERISA's civil enforcement provision, see id. at 1325, the court stated that "because ERISA pre-emption is so comprehensive, pre-emption defense [i.e., "conflict" preemption] provides sufficient basis for removal to federal court notwithstanding [the] "well-pleaded complaint rule."' Id. at 1325 n.4 (citing Metropolitan Life Ins. Co. v. Taylor, 481 U.S. 58, 66 (1987)). Of course, this is an incorrect citation of Metropolitan Life: in that case the Supreme Court referred to "complete preemption" under ERISA's civil enforcement provision, not conflict preemption under the statute's preemption provision. See Metropolitan Life Ins. Co., 481 U.S. at 66; see also infra Section I.I (discussing jurisdictional confusion in the courts).

102. See Corcoran, 965 F.2d at 1325.

103. See id. at 1326.

104. See id. at 1339.

105. Id. at 1331.

106. Id. at 1334 .

107. See id. at 1333 ("We are not unmindful of the fact that our interpretation of the preemption clause leaves a gap in remedies within a statute intended to protect participants in employee benefit plans ...."); id. at 1338 ("The result ERISA compels us to reach means that the [plaintiffs] have no remedy, state or federal, for what may have been a serious mistake."); $c f$. Pilot Life Ins. Co. v. Dedeaux, 481 U.S. 41, 54 (1987) ("The policy choices reflected in the inclusion of certain remedies and the exclusion of others under the federal scheme would be com- 
amended their complaint while in district court to assert a claim for extracontractual damages under ERISA's grant to courts of equitable powers of relief for violations of the terms of the plan ${ }^{108}$ However, like in Settles, the court rejected the applicability of the equitable powers to the extracontractual damage claims ${ }^{109}$ and affirmed the district court's grant of summary judgment. ${ }^{100}$

Hence, in these direct-liability cases the MCOs' ERISA shield is strong against patient injury claims that are in fact and in characterization the result of benefit denials and administration errors and plaintiffs almost always go home losers. These results provide a clear incentive for the ERISA MCO: Deny care at any and all junctures to exploit the preemptive effects of ERISA's civil enforcement and preemption provisions. Legislative action and judicial interpretation have thus created a system that allows MCOs to avoid culpability for medical decisions that have arguably injured patients.

\section{The Dukes Difference: Quality, not Quantity}

Although courts have consistently rejected direct-liability claims against MCOs in the ERISA context, the thick ERISA shield is not seamless. A crack that allows state-law claims against MCOs to avoid preemption under ERISA's civil enforcement provision has been seized upon by plaintiffs. In Dukes v. U.S. Healthcare, ${ }^{111}$ the Third Circuit Court of Appeals held that it did not have jurisdiction under the ERISA statute to hear the plaintiffs' direct and indirect state-law claims against the $\mathrm{MCO}$ and medical providers, and remanded the cases to state court. ${ }^{12}$ The Dukes case involved two fact scenarios consolidated on appeal. In the first, Darryl Dukes, who obtained his health benefits through an ERISA EBP, presented to his physician with symptoms implicating his inner ear. Dukes's ERISA health plan was administered by U.S. Health-

pletely undermined if ERISA-plan participants and beneficiaries were free to obtain remedies under state law that Congress rejected in ERISA."); Tolton v. American Biodyne, 48 F.3d 937, 943 (6th Cir. 1995) ("One consequence of ERISA preemption, therefore, is that plan beneficiaries or participants bringing certain types of state actions-such as wrongful death-may be left without meaningful remedy."); Cromwell v. Equicor-Equitable HCA Corp., 944 F.2d 1272, 1276 (6th Cir. 1991) ("Nor is it relevant to an analysis of the scope of federal preemption that appellants may be left without remedy."); Andrews-Clark v. Travelers Ins. Co., 984 F. Supp. 49 n.26 (D. Mass. 1997) ("Despite arguments to the contrary, it is widely recognized that the absence of a comparable remedy under ERISA does not alter the analysis concerning preemption of the state law claims." (citations omitted)).

108. See Corcoran, 965 F.2d at 1335; see also 29 U.S.C. $§ 1132$ (a)(3) (1994).

109. See Corcoran, 965 F.2d at 1334-38.

110. See id. at 1339.

111. 57 F.3d 350 (3d Cir.), cert. denied, 516 U.S. 1009 (1995).

112. See id. at 352 . 
care. His physician performed surgery and ordered laboratory studies, but the laboratory at the hospital refused to carry out the tests. Dukes then went to another physician at another hospital who ordered another set of blood tests. This time the tests were done. Dukes's condition deteriorated, however, and he subsequently died. At the time of his death he was found to have significant hyperglycemia. ${ }^{113}$ Dukes's wife instituted an action in state court claiming medical malpractice and other negligencebased causes of action against the physicians and hospitals as well as direct- and vicarious-liability claims against the MCO. The case was removed to federal district court where the claims against the $\mathrm{MCO}$ were dismissed and the claims against the providers were remanded. ${ }^{114}$ Dukes appealed to the Third Circuit where her action was consolidated with the Visconti case. ${ }^{115}$

Plaintiffs Ronald and Linda Visconti, who also received their health benefits through an ERISA EBP administered by U.S. Healthcare, sued U.S. Healthcare in state court after their child was stillborn. ${ }^{116}$ They claimed that their obstetrician was negligent in ignoring Linda's symptoms of preeclampsia during her third trimester of pregnancy and that this negligence led to the death of the fetus. ${ }^{117}$ They also brought suit in state court against the MCO for both direct and vicarious liability. Again, U.S. Healthcare removed to federal court where the district judge granted the MCO's motion to dismiss. The Viscontis appealed and their case was consolidated with the Dukes case. ${ }^{118}$

The court of appeals held that, because the plaintiffs "merely attack[ed] the quality of the benefits they received" "to recover benefits due ... under the terms of [the] plan, to enforce... rights under the terms of the plan, or to clarify ... rights to future benefits under the terms of the plan" ${ }^{120}$ under ERISA's civil enforcement provision, each district court had lacked jurisdiction to hear its respective case. It noted that the only proper action for each of the courts below was to remand its case to state court. ${ }^{121}$

\author{
113. See id. \\ 114, See id. at 352-53. \\ 115. See id. at 353 . \\ 116. See id. \\ 117. See id. \\ 118. See id. \\ 119. Id. at 356 . \\ 120. 29 U.S.C. $\$ 1132(a)(1)(B)$ (1994). \\ 121. See Dukes, 57 F.3d at 352 .
}




\section{E. The Dukes Rationale}

The rationale behind the Dukes court's conclusion brings us into the murky area of the "well pleaded complaint rule" and its exception, the "complete preemption doctrine." Generally, under the well pleaded complaint rule, only if a cause of action "arises under" federal law and a federal question is presented on the face of the properly pleaded complaint will removal from state to federal court be appropriate. ${ }^{122} \mathrm{~A}$ federal defense to a state cause of action, such as federal preemption of state law (i.e., "conflict preemption"), will usually not appear on the face of a well pleaded complaint and is thus not sufficient grounds for removal to federal court. The policy is to allow the plaintiff to control his or her cause of action. $^{123}$

As an exception to the well pleaded complaint rule, however, the Supreme Court has held that, under the "complete preemption doctrine," "Congress may so completely preempt a particular area [such] that any civil complaint raising [a] select group of claims is necessarily federal in character" and removable to federal court, even if a federal issue does not appear on the face of the plaintiff's complaint. ${ }^{124}$ The foundation for the complete preemption doctrine is that, for these claims, "the preemptive force of [the federal law] is so powerful as to displace entirely any state cause of action [within the federal statute's scope]. Any such suit is purely a creature of federal law, notwithstanding the fact that state law would provide a cause of action in the absence of [the federal statute]."125

Although the Dukes court noted that the Supreme Court had held that the complete preemption doctrine applied to state-law causes of action within the scope of section 502 of ERISA, the statute's civil en-

122. See Franchise Tax Bd. v. Construction Laborers Vacation Trust, 463 U.S. 1, 8-12 (1983); see also Louisville \& Nashville R.R. v. Mottley, 211 U.S. 149, 152 (1908) (stating that a federal preemption defense that does not appear on the face of a well pleaded complaint is insufficient to permit removal to federal court). See generally 28 U.S.C. $\$ 1441$ (1994) (describing actions removable generally). Note that removal is also allowed on diversity grounds. See 28 U.S.C. \& 1141(b) (1994) (describing requirements for removing claims on the basis of diversity). Diversity information would generally be apparent on the face of a well pleaded complaint.

123. See Caterpillar Inc. v. Williams, 482 U.S. 386, 398 (1987); Gully v. First Nat'l Bank, 299 U.S. 109, 115-18 (1936).

124. See Metropolitan Life Ins. Co. v. Taylor, 481 U.S. 58, 63-64 (1987). This doctrine was created in Avco Corp. v. Aero Lodge No. 735, 390 U.S. 557 (1968) (holding that state-law claims within the scope of section 301 of the Labor Management Relations Act were removable to federal court and completely preempted). The complete preemption doctrine, of course, "is not a preemption doctrine but rather a federal jurisdiction doctrine." Lister v. Stark, 890 F.2d 941, 943 n.1 (7th Cir. 1989). Indeed, state causes of action not removable under ERISA's civil enforcement provision are still subject to preemption in state court under ERISA's preemption provision. See Warner v. Ford Motor Co., 46 F.3d 531, 535 (6th Cir. 1995).

125. Franchise Tax Bd., 463 U.S. at 23. 
forcement provision, ${ }^{126}$ the court appropriately recognized that the possible preemption of a cause of action by federal law does not make all these causes of action removable to federal court. ${ }^{127}$ Even if the state causes of action are preempted under section 514 of ERISA, the preemption provision, ${ }^{128}$ that fact alone does not provide removal jurisdiction to a federal court.

When the doctrine of complete preemption does not apply, but the plaintiff's state claim is arguably preempted under [ERISA's preemption provision], the district court, being without removal jurisdiction, cannot resolve the dispute regarding preemption. It lacks power to do anything other than remand to the state court where the preemption issue can be addressed and resolved. $^{129}$

It is important to note that, for state-law claims asserting quality concerns and indirect causes of action against the $\mathrm{MCO}$, the Dukes court did not conclude that the claims were not preempted by ERISA's preemption provision but rather found that the appropriate forum to decide that issue was the state court.

State-law causes of action within the scope of ERISA's civil enforcement provision asserting claims associated with denial of benefits and administrative difficulties are subject to federal jurisdiction under the complete preemption doctrine and are completely preempted. In contrast, state causes of action that assert quality and indirect claims are not within the reach of ERISA's civil enforcement provision but may be subject to conflict preemption by ERISA's preemption provision. However, the possibility of conflict preemption does not by itself provide a basis for federal jurisdiction.

The Dukes court held that, because the state-law claims alleged that the care provided was of poor quality and that the MCO was negligent in arranging for its provision but did not allege that the benefits of the plan were withheld or denied, ERISA's civil enforcement provision was not implicated. These causes of action escaped the jurisdictional scope of the complete preemption doctrine. ${ }^{130}$ The federal courts did not have jurisdic-

126. See Dukes, 57 F.3d at 354 (citing Metropolitan Life Ins. Co., 481 U.S. at 66). Section 502 of ERISA is codified at 29 U.S.CA. $\$ 1132$ (West 1985 \& Supp. 1998).

127. See Dukes, 57 F.3d at 355.

128. 29 U.S.C.A. $\$ 1144$ (West 1985 \& Supp. 1998).

129. Dukes, $57 \mathrm{~F} .3 \mathrm{~d}$ at 355.

130. On this point, the court explained:

[P]laintiffs' claims ... merely attack the quality of the benefits they received: The plaintiffs here simply do not claim that the plans erroneously witheld benefits due. Nor do they ask the state courts to enforce their rights under the terms of their respective plans or to clarify their rights to future benefits. As a result, the plaintiffs' claims fall outside of the scope of [the ERISA civil enforcement provision,] and these cases must be remanded to the state courts from which they were removed. 
tion to hear the cases and were thus required to remand them to state court. Dukes is therefore a crack in the ERISA shield that allows a plaintiff's state-law claims to avoid the statute's civil enforcement provision and complete preemption. The claims survive federal court, but they must face the statute's preemption clause back in state court.

\section{F. Some Concerns with Dukes}

The distinction between denying care and providing poor-quality care that the Dukes court made to preserve plaintiffs' state-law claims is arguably weak for several reasons. First, it leads to the absurd conclusion that the law requires that causes of action based on a complete denial of care-or care of such poor quality that it amounts to no care-are preempted by the complete preemption doctrine, ${ }^{131}$ while claims based on a partial denial of benefits that drop to "poor" quality-but not such poor quality that the care is considered no care-are not. Further, concerns about quality in the performance of a contract have been consistently noted by the Supreme Court to be within the complete preemption doctrine. For example, in Allis-Chalmers Corp. v. Lueck, ${ }^{132}$ the Court held that section 301 of the Labor Management Relations Act, the section and act on which the complete preemption doctrine was founded, preempted the plaintiff's state-law claim of bad-faith processing of an insurance claim. ${ }^{133}$ The Court noted that good-faith administration of benefits was inextricably linked to the section 301 contract and held that, as a result, adjudicating the case would inevitably involve interpreting the contract. In Pilot Life Insurance Co. v. Dedeaux, ${ }^{134}$ the Court indicated that ERISA's civil enforcement provision completely preempted a state-law claim for bad-faith or tortious breach of contract. Similarly, in Metropolitan Life Insurance Co. v. Taylor, ${ }^{135}$ the Court extended its analysis of ERISA's civil enforcement provision by noting that emotional-distress claims were similarly completely preempted. It would appear that assessing the quality of medical services rendered requires an inquiry into the nature of ERISA EBP contractual provisions defining good- or badfaith and tortious performance, i.e., into whether the service levels provided by the plan comported with how much and how well they were supposed to be provided.

Id. at 356. However, the rationale that the court uses to justify this conclusion is suspect. See infra Section I.F (discussing the weakness of the Dukes decision).

131. See supra notes $124-130$ and accompanying text.

132. 471 U.S. 202 (1985).

133. See id. at $219-20$.

134. 481 U.S. 41,51 (1987).

135. 481 U.S. 58, 66 (1987). 
Although the Dukes court attempts to avoid this argument by indicating that no one contracts for negligent care, ${ }^{136}$ it does not address the substantive issue. In agreements about the amount and kind of healthcare services to be provided, there are always different levels and types of care that can be rendered to the patient. Some plans require that patients see non-physicians such as physician assistants and nurse practitioners at the outset, while others allow direct access to physicians. ${ }^{137}$ Each of these providers has a different capacity to perform different types of services, a different knowledge level to bring to bear on a clinical problem, and a different likelihood of performing a diagnosis or procedure "correctly."138 Indeed, if these considerations were not inherent in healthcare delivery today, there would be no difference between non-physicians and physi-

136. See Dukes, 57 F.3d at 358 ("[P]atients enjoy the right to be free from medical malpractice regardless of whether or not their medical care is provided through an ERISA plan.").

137. Indeed, even the kind of physician is a contractually determined issue. Whether the beneficiary can see specialists directly or whether a referral from a primary care physician is required for coverage, whether self-referral to a specialist provides some, but not full, coverage, and whether coverage extends to some portion or all of the services obtained from non-MCO physicians are all issues that need to be assessed by reviewing the contract.

138. The approach to a clinical problem can reasonably encompass a wide range of acceptable variation. See generally JOHN M. EISENBERG, DOCTORS' DeCISIONS AND THE COST OF Medical Care: The Reasons for Doctors' Practice Patterns and the Ways To CHANGE THEM (1986) (outlining variations in cardiac angiogram interpretation); Alfred $O$. Berg, Variations Among Family Physicians' Management Strategies for Lower Urinary Tract Infections in Women: A Report from the Washington Family Physicians Collaborative Research Network, 4 J. AM. BOARD FAM. PRAC. 327 (1991) (indicating variations in physician treatment of urinary tract infections); Joann G. Elmore et al., Variability in Radiologists' Interpretations of Mammograms, 331 NEw ENG. J. MED. 1493 (1994) (showing variations in interpretations and recommendations for management between radiologists); Bryan A. Liang et al., Analysis of the Resource-Based Relative Value Scale for Medicare Reimbursements to Academic and Community Hospital Radiology Departments, 179 RADIOLOGY 751, 754-58 (1991) (reporting differences in the assessment of radiologic work between physicians practicing at community hospitals and academic medical centers); Bryan A. Liang, Assessing Medical Malpractice Jury Verdicts: A Case Study of an Anesthesiology Department, 7 CORNELL J.L. \& PUB. POL'Y 121 (1998) (noting that there is broad divergence of assessment of negligent and acceptable care by academic anesthesiologists) [hereinafter Liang, Jury Verdicts]; Bryan A. Liang, Medical Malpractice: Do Physicians Have Knowledge of Legal Standards and Assess Cases as Juries Do?, 3 U. CHI. L. SCH. RoundTABLE 59 (1996) (discussing the broad divergence of assessment of negligent and acceptable care by academic radiologists) [hereinafter Liang, Medical Malpractice]; Jack E. Meyer et al., Biopsy of Occult Breast Lesions: Analysis of 1261 Abnormalities, 263 JAMA 2341 (1990) (indicating that community-based radiologists may be more aggressive in their recommendations than academic radiologists when presented with suspicious lesions on mammograms); Jack E. Wennberg \& Alan Gittlesohn, Variations in Medical Care Among Small Areas, SCI. AM., Apr. 1982, at 120 (reviewing variation among providers in assessing indications for prostate, thyroid, or coronary bypass surgery). This variance becomes even broader when medical providers beyond the traditional physician are introduced, which has led some to advocate a standard of care that is a function of the delivery mode. See, e.g., Jonathan J. Frankel, Note, Medical Malpractice Law and Health Care Cost Containment: Lessons for Reforms from the Clash of Cultures, 103 YALE L.J. 1297, 1326-27 (1994). 
cians in MCOs. Yet surely there is a difference, as can be seen by comparing the price of a plan that allows direct access to physicians to one that requires patients to see non-physicians first. Thus, determining what level or "quality" of care is appropriate for a particular ERISA beneficiary in a malpractice case requires an investigation of the type of provider required by the plan: The type of provider will determine the probability of a missed diagnosis or an "incorrectly" performed procedure, which are factors in deciding what "quality" of care is mandated by the ERISA plan. Since this quality concern clearly implicates the EBP, it is within the scope of ERISA's civil enforcement provision and the complete preemption doctrine.

Further, even assuming the ERISA EBP is mandated by its terms to provide the beneficiary only nonnegligent care, when the care provided is purportedly negligent the claim against the $\mathrm{MCO}$ is to recover for the "correct" benefit of nonnegligent care rather than the "incorrect" negligent care provided. Indeed, if the beneficiary is provided the "incorrect" benefits in any other part of the EBP-inappropriately low pension payments, for example-courts would easily find that claims for tort or consequential damages resulting from being provided the low benefits are preempted under the statute's civil enforcement provision. ${ }^{139}$

Finally, the quality consideration may simply be specious. Recall the many strong circuit court decisions holding that direct suits encompass a broad array of negligence claims against MCOs that are preempted under both ERISA's civil enforcement and preemption provisions when the claims are construed as a faulty administration of benefits, a denial of benefits, or otherwise. Many of the direct quality-type claims allowed by Dukes could be subsumed within these analyses. ${ }^{140}$ Thus, the Dukes ra-

139. Section 502 simply provides the exclusive remedy in these situations. See, e.g., Slice v. Sons of Norway, 34 F.3d 630, 633 (8th Cir. 1994) (stating that actions by a retiree seeking compensatory and punitive damages for breach of contract and breach of fiduciary duty for reduced ERISA pension benefits were preempted by $\S 502$ ); Harsch v. Eisenberg, 956 F.2d 651, 656, 660-61 (7th Cir. 1992) (stating that extracontractual or punitive damages are not available under ERISA for financial losses resulting from a delay in the payment of pension benefits).

140. See, e.g., Turner v. Fallon Community Health Plan, 127 F.3d 196 (1st Cir. 1997) (discussing breach of contract and wrongful death); Tolton v. American Biodyne, 48 F.3d 937 (6th Cir. 1995) (discussing wrongful death, improper refusal to authorize benefits, medical malpractice against plan, insurance bad faith, breach of contract, negligent retention of healthcare services, and loss of consortium); Spain v. Aetna Life Ins. Co., 11 F.3d 129 (9th Cir. 1993) (discussing wrongful death); Kuhl v. Lincoln Nat'l Health Plan, 999 F.2d 298 (8th Cir. 1993) (discussing medical malpractice, emotional distress, tortious interference with participant's right to contract for medical care, and breach of contract); Settles v. Golden Rule Ins. Co., 927 F.2d 505 (10th Cir. 1991) (discussing breach of contract, tort of outrage, fra udulent denial of insurance coverage, and wrongful death); Corcoran v. United Healthcare, 965 F.2d 1321 (5th Cir. 1992) (discussing wrongful death, loss of consortium, and emotional distress); see also supra Section I.C (discussing Turner, Tolton, Spain, Kuhl, Settles, and Corcoran); Dalton v. Peninsula 
tionale is arguably weak. More important, and as the next Section addresses, it may also create undesirable incentives that compound the problem it attempts to correct.

\section{G. Incentives: Deny, Deny, Deny Even More}

Dukes has breathed new life into MCO liability suits by allowing them to go forward, with the caveat that state, rather than federal, courts must decide whether these "quality" suits are preempted by ERISA. ${ }^{141}$ Many federal district courts have followed Dukes and remanded direct negligence and other state-law claims against ERISA MCOs to state courts. ${ }^{142}$

While there may indeed be a crack in the ERISA shield on the basis of the quality-versus-quantity distinction, it bears emphasizing that this does not solve all of a plaintiff's ERISA concerns. There are difficulties with the distinction that may yet bring the quality claims under ERISA's civil enforcement provision. ${ }^{143}$ Moreover, even if the quality-based claims are not ultimately construed as within the ambit of the civil enforcement provision and a plaintiff is able to pierce the complete preemption shield,

Hosp. Ctr., 626 N.Y.S.2d 362 (Sup. Ct. 1995) (discussing negligent administration, negligent selection, and wrongful death claims preempted by ERISA).

141. See Dukes, 57 F.3d at 361 ("Our holding that the districts [sic] courts lack removal jurisdiction, of course, leaves open for resolution by the state courts the issue of whether the plaintiffs' claims are preempted under [ERISA's preemption provisions]."); see also Lupo v. Human Affairs Int'l, 28 F.3d 269, 272 (2d Cir. 1994) (stating that removal to federal court is inappropriate for claims against an EBP in a malpractice action against a psychologist). Incredibly enough, the Dukes court concluded that a federal statute in an area of exclusive federal concern should be interpreted by a state court. See Karen A. Jordon, The Complete Preemption Dilemma: A Legal Process Perspective, 31 WAKE FOREST L. REv. 927 (1996). Indeed, as a further irony, while the Dukes court was using the formalist tool to preserve the causes of action before it (by finding the "quality" cause of action not within the strict confines of the text of ERISA's civil enforcement provision and thus not subject to the complete preemption doctrine), the Supreme Court in Travelers construed ERISA in an anti-formalist way that also limited the provision's preemptive scope. See New York State Conference of Blue Cross \& Blue Shield Plans v. Travelers Ins. Co., 514 U.S. 645 (1995).

142. See, e.g., Lancaster v. Kaiser Found. Health Plan, 958 F. Supp. 1137 (E.D. Va. 1997) (remanding state-law vicarious-liability claims against MCO since they are outside the statute's civil enforcement provision); Morrison v. Seafarers Int'l Union, 954 F. Supp. 55 (E.D.N.Y. 1996) (stating that because medical malpractice claims against physicians and an ERISA health plan did not raise ERISA civil enforcement provision issues, the court had no subject matter jurisdiction); Fritts v. Khoury, 933 F. Supp. 668 (E.D. Mich. 1996) (quoting Dukes as to the quality versus quantity distinction and remanding direct and vicarious negligence claims to state court); Roessert v. Health Net, 929 F. Supp. 343 (N.D. Cal. 1996) (finding that direct claims of negligence against an $\mathrm{MCO}$ for involuntarily committing a patient to a psychiatric facility do not fall within the civil enforcement provision and remanding the case). But cf. Schmid v. Kaiser Found. Health Plan, 963 F. Supp. 942 (D. Or. 1997) (distinguishing Dukes by holding that ERISA preempts negligence claims based on a determination or denial of benefits).

143. See supra Section I.F (criticizing Dukes). 
the first test the claim faces in state court is not a hearing on the merits but rather a determination of whether it is preempted by ERISA's preemption provision. Only if that issue is resolved favorably for the plaintiff may the state-law claims be tried on the merits.

Dukes thus represents a tenuous inroad against ERISA MCOs in the current healthcare delivery system. Dukes raises a more troubling problem, however. While useful in the short term for plaintiffs who face having their cases lost on complete preemption grounds in federal court, the case enhances the very disturbing incentive for $\mathrm{MCO}$ created by section 502. To avoid the machinations of Dukes, MCOs may simply deny care so as to avoid the quality distinction altogether. It bears emphasizing that the circuit court and Supreme Court decisions addressing the issue of ERISA preemption of direct-liability claims against MCOs conclude firmly that:

[I]t is undisputed that ERISA's civil enforcement provision does not authorize recovery for wrongful death, personal injury, or other consequential damages caused by the improper refusal of an insurer or utilization review provider to authorize treatment. Thus, the practical impact of ERISA ... is to immunize [insurers and utilization review companies] from any potential liability for the consequences of their denial of benefits. ${ }^{144}$

Hence, the Dukes decision ultimately provides MCOs with an incentive to place additional financial and other constraints on physicians attempting to render, and on patients attempting to obtain, healthcare, even though at one time MCOs would have considered authorizing such care. By denying care and avoiding the quality issue, MCOs will fall squarely within ERISA's civil enforcement provision and will almost certainly have federal courts grant summary judgment in their favor.

\section{H. Indirect MCO Liability}

It is apparent that the path of attempting to hold ERISA MCOs directly liable is fraught with unexpected twists and turns for the unwary. As the preceding Sections demonstrate, if a plaintiff pleads direct statelaw liability on the basis of improper benefit administration, denial of benefits, or some other direct claim ${ }^{145}$ against an ERISA MCO, he or she is very likely to have his or her action dismissed by a federal court with no opportunity for adjudication on the merits. By claiming that a directliability suit against the MCO is based on "quality" concerns rather than quantity, the plaintiff may pierce the shield of ERISA's civil enforcement provision but then must survive a state court's analysis under the statute's

144. Andrews-Clarke v. Travelers Ins. Co., 984 F. Supp. 49, 55-56 (D. Mass. 1997) (footnotes omitted).

145. See supra Sections I.C-G (discussing direct-liability actions against MCOs). 
preemption provision before the claims can be adjudicated on the merits.

However, the Dukes court identified another potential line of attack for plaintiffs and their attorneys against the ERISA shield. The court held that vicarious-liability and ostensible-agency claims against an $\mathrm{MCO}$ for the actions of its medical providers were not within the scope of ERISA's civil enforcement provision. ${ }^{146}$ This Section will demonstrate that, in contrast to the relatively consistent application of preemption doctrine to defeat direct state-law claims under a denial of benefits or negligent administration theory, there is significant conflict in the courts over whether indirect-liability claims against MCOs are preempted under ERISA. Indeed, it is on this issue that the battles and substantive attacks against the ERISA shields are being waged currently.

The tortured jurisprudence in the federal circuit courts on the indirect-liability question illustrates the conflict. In Jass $v$. Prudential Health Care Plan ${ }^{147}$ the most recent court of appeals decision on the preemption of indirect-liability claims against ERISA MCOs, the Seventh Circuit held that vicarious-liability and ostensible-agency claims were preempted by ERISA. ${ }^{148}$ After an extended jurisdictional analysis, the court performed a civil enforcement provision assessment of the claims as well as a determination of whether they were subject to conflict preemption under the preemption clause.

Jass brought state-law claims in state court after obtaining allegedly negligent care from her physician and an inappropriate denial of rehabilitation care from a nurse acting as a utilization review provider. Jass's action included direct-liability claims against the nurse and physician as well as vicarious-liability claims against the $\mathrm{MCO}$ for the actions of both of them. Defendants removed to federal district court, where all claims against the nurse and the MCO were held to be preempted on the basis of section 514. The court remanded the medical malpractice claim against the physician. ${ }^{149}$ Jass appealed. ${ }^{150}$

The Seventh Circuit provided a thorough analysis of the interplay between ERISA's civil enforcement provision, the preemption provision, and the relevant jurisdictional give-and-take when deciding whether plaintiff's state-law claims were preempted. First, the court exercised jurisdiction over all claims on the basis of both diversity of citizenship and the presence of a federal question. ${ }^{151}$ Next, the court dismissed Jass's

146. See Dukes v. U.S. Healthcare, 57 F.3d 350, 360 (3d Cir.), cert. denied, 516 U.S. 1009 (1995).

147. 88 F.3d 1482 (7th Cir. 1996).

148. See id. at 1487-88.

149. See id. at 1484 .

150. See id.

151. At the time the complaint was removed, the physician was not a defendant and the 
claims against the nurse as representative of the plan. Consistent with all previous federal circuit courts that have considered the issue, the court held that a denial of a claim for care is a determination of benefits within the meaning of civil enforcement provision of ERISA and thus is completely preempted. ${ }^{152}$ The court noted that Jass's attempt to "artfully" plead to avoid a federal question was to no avail and that future courts could pierce these characterizations and even deny plaintiffs the opportunity to amend. ${ }^{153}$ The court similarly held that plaintiff's negligence claim against the nurse as a utilization review provider was completely preempted under ERISA's civil enforcement provision.

[Plaintiff's] negligence claim against [the nurse utilization review provider] cannot be resolved without interpreting the benefits contract because that contract provided the benefits to which [plaintiff] was entitled. See Rice, 65 F.3d at 644 (where state law creates a quality standard by which performance of the contract is evaluated then that state law is completely preempted). As the Supreme Court stated in [Pilot Life], "Congress ... ma[d]e clear its intention that all suits brought by beneficiaries or participants asserting improper processing of claims under ERISA-regulated plans be treated as federal questions governed by [the civil enforcement provision]."

The court also noted that the plaintiff, in naming the nurse utilization review provider, brought suit against the wrong party:

Here... the claim against [the nurse utilization reviewer] is really a federal denial of benefits claim under [ERISA's civil enforcement provision] and not a state law claim.

The claim was nonetheless properly dismissed because [plaintiff] sued [the nurse utilization reviewer] in an individual capacity and "ERISA permits suits to recover benefits only against the Plan as an entity ....",

The court also dismissed all of Jass's vicarious-liability claims against the $\mathrm{MCO}$ that were derived from the completely preempted claim against the nurse. "Jass's claim against [the MCO] for vicarious liability based on [the utilization reviewer's] actions is also a[n] [ERISA civil enforcement claim for] denial of benefits.... (After all, a corporate 'plan' can only

parties were completely diverse. Complete diversity was destroyed when the plaintiff added the claim against the physician but restored when the district court dismissed that claim. Thus the court of appeals had jurisdiction over all the remaining claims. See id. at 1491-92.

152. See id. at 1489; see also supra Sections I.C-G (reviewing direct-liability claims for denial of benefits and the implications thereof).

153. See Jass, 88 F.3d at $1489,1491$.

154. Id. at 1489-90 (citing Rice v. Panchal, 65 F.3d 637 (7th Cir. 1995) and quoting Pilot Life Ins. Co. v. Dedeaux, 481 U.S. 41, 56 (1987)).

155. Id. at 1490 (citing Gelardi v. Pertec Computer Corp., 761 F.2d 1323, 1324 (9th Cir. 1985)). 
deny benefits through its agents, of which [the reviewer] was one.).... As such, it is completely preempted."156

The court then discussed the MCO's potential vicarious or ostensibleagency liability for the actions of the physician. The court held these claims were, akin to the Dukes analysis, outside the realm of ERISA's civil enforcement provision and thus not completely preempted. ${ }^{157}$ The court, however, was not obligated to remand the case to state court since it had diversity jurisdiction. ${ }^{158}$ Therefore, it could validly decide whether ERISA section 514 conflict preemption reached Jass's vicarious-liability claims against the MCO that were based on the physician's action, i.e., whether her claims "relate[d] to" the EBP. The court concluded that they did. First, the court noted that the EBP listed the physician as a preferred physician and, as is typical of the vast majority of MCOs, provided higher benefits if plan participants went to him instead of an unlisted provider.

156. Id. at 1491 (citation omitted); see also Clark v. Humana Kansas City, 975 F. Supp. 1283 (D. Kan. 1997). In Clark, the court noted:

Plaintiff requests leave to amend her complaint for the second time to assert a negligence claim against [the ERISA MCO], by which plaintiff would seek to impart vicarious liability on [the $\mathrm{MCO}$ ] for the alleged negligence of its ostensible agent [provider who did not authorize benefits]. Just as plaintiff's claims against [the provider] are preempted, so too would ERISA preempt a claim against [the MCO] based on that same conduct....

Id. at 1289 .

157. See Jass, 88 F.3d at 1491-92. Note that an earlier Seventh Circuit case held that vicarious-liability claims were not within the scope of ERISA's civil enforcement provision, were thus not completely preempted, and should be remanded to the state court due to lack of jurisdiction. See Rice v. Panchal, 65 F.3d 637 (7th Cir. 1995). The Rice reasoning, however, is extremely suspect on the applicability of section 502. Rice involves vicarious-liability claims against an ERISA MCO for physician actions in providing treatment. The terms of the EBP incorporate the following:

The Plan defines a "Prudential Health Care Provider" as "A Doctor, Hospital or other provider of medical services or supplies which has agreed with Prudential, directly or indirectly, to arrange to provide for furnishing medical or surgical services and supplies to Covered Persons. Such services and supplies may be furnished at predetermined amounts."

Id. at $642 \mathrm{n} .5$ (emphasis added). Yet, to avoid the conclusion that plaintiff's suit was to recover benefits due under the plan under the civil enforcement provision, the court simply repeated several times that there was no requirement to look to the agreement: "'[R]esolution of the state law claim does not require construing the ... agreement." Id. at 643 (omission in original) (quoting Lingle v. Norge Div. of Magic Chef, 486 U.S. 399, 407 (1988)). "[Plaintiff] has not rested his claim on the terms of the Plan ...." Id. at 645. "[Plaintiff's] claim does not involve the interpretation of the ERISA plan, and cannot be recharacterized as a suit within the scope of [ERISA's civil enforcement provisions]." Id. However, it was the very essence of the plaintiff's claim that required an assessment of what "predetermined amounts" of care the MCO was obligated to provide-an inquiry directly relating to the EBP itself. Thus, it would appear that plaintiff's claims fall directly within a civil enforcement provision analysis and should have been preempted.

158. See infra notes 171-177 and accompanying text (indicating the bases for federal jurisdiction). 
Thus, if some form of agency were extant between the physician and the MCO, "it was solely as a result of the [MCO's] healthcare plan of which Jass was a participant." 159 Second, the court noted that:

[T] determine whether an actual or apparent agency relationship existed between [the physician] and [the MCO] would require an examination of the healthcare benefit plan to determine the relationship between [the physician], [the MCO] and Jass. In fact, the health benefit plan contains a section entitled "relation among parties affected by the group contract," which states that no participating physician is an employee or agent of [the MCO]. ${ }^{160}$

The court "note[d] [these factors] not to resolve the question of agency, but to highlight that Jass's claims 'relate to' the health benefit plan." Thus, the court held that the indirect claims against the ERISA MCO were preempted by the statute's preemption provision.

The court, however, muddied the waters of this agency analysis in dicta by implicating the characteristics of a denial of benefits claim. The court noted that:

[t]he specific allegations in this case further support the conclusion that Jass's claims "relate to" the benefit plan. The alleged negligence of [the physician] underlying the vicarious liability claims against the [MCO] do[es] not assert his negligent treatment, but his negligent failure to treat. This alleged negligence directly "relate[s] to the benefit plan" because [the physician's] failure to treat stemmed from [the utilization reviewer's] denial of benefits .... ${ }^{162}$

According to this text, there is some question as to whether a relation between the vicarious-liability claim and some denial of benefits is required to provide a court with justification to dismiss the indirect-liability claim as preempted under ERISA's preemption provision. There is support for each interpretation in the balance of the court's opinion. ${ }^{163}$

159. Jass, 88 F.3d at 1493.

160. Id.

161. Id. (citing Ingersoll-Rand Co. v. McClendon, 498 U.S. 133, 139-40 (1990)).

162. Id. (citing Spain v. Aetna Life Ins. Co., 11 F.3d 129, 131 (9th Cir. 1993); First Nat'l Life Ins. v. Sunshine Jr. Food Stores, 960 F.2d 1546, 1550 (11th Cir. 1992)) (emphasis added).

163. For example, as noted in the text, the court indicated that this relationship further supports their formally stated holding rather than basing its holding on this factor of the case; in addition, the court states: "To allow a vicarious liability claim against an ERISA Plan for the alleged negligence of a listed physician would require multi-state plans to vary their plan administration to avoid strict vicarious liability under differing state laws [and thus contravene Congress's clear intent]." Jass, 88 F.3d at 1494; cf. id. at 1495. The Jass court addressed the Tenth Circuit's decision in Pacificare of Oklahoma v. Burrage, 59 F.3d 151 (10th Cir. 1995), which allowed a vicarious-liability claim to go forward against an ERISA MCO:

[T] he Tenth Circuit cited the lower court's rationale that a vicarious liability claim against an HMO for medical malpractice does not sufficiently "relate to" the plan so as to warrant preemption because the issue of the doctor's negligence can be resolved without reference to the benefit plan. In this case, however, [the physician's] alleged negligence is intertwined with the benefits determination because the alleged negli- 
In contrast, in the only other published court of appeals decision on the matter ${ }^{164}$ Pacificare of Oklahoma v. Burrage, ${ }^{165}$ the Tenth Circuit Court of Appeals held that a vicarious-liability claim against an MCO for the alleged malpractice of a provider is not subject to conflict preemption under ERISA section 514. The court remanded the case to state court for adjudication. ${ }^{166}$ Unfortunately, the court limited its discussion only to whether the claim fell under the preemption provision of ERISA rather than first assessing whether it was within the scope of the statute's civil enforcement provision; indeed, there are jurisdictional questions as to whether the court should have ever reached the substantive issue it decided. ${ }^{167} \mathrm{Be}$ that as it may, the Tenth Circuit held, in direct opposition to

gence concerned a failure to treat where the Plan denied payment for the treatment. Pacificare also seems distinguishable because in that case, the doctor alleged to have been negligent was "one of [the HMO's] physicians," while here [the physician] appears to be a private doctor with whom [the $\mathrm{MCO}$ ] entered into an independent contract relationship to provide treatment to participants.

Jass, 88 F.3d at 1494. And to further make it difficult to separate the wheat from the chaff: [The cases that have survived preemption have not] involved a suit by a plan participant against a plan. Nor did they concern allegations of negligence based on a failure to treat where the plan denied benefits for the proposed treatment. They also involve relationships arising from something other than a benefit plan, while here the sole basis for any relationship between [the $\mathrm{MCO}$ ] and [plaintiff], [the $\mathrm{MCO}$ ] and [the physician], and [the physician] and [plaintiff] arises solely from the health benefit plan [the $\mathrm{MCO}$ provided [plaintiff].

Id. at 1495 .

164. This statement is not entirely true. In another case, Kuhl v. Lincoln Nat'l Health Plan, 999 F.2d 298, 304 (8th Cir. 1993), the Eight Circuit Court of Appeals dealt very briefly and indirectly with this issue in the context of emotional distress.

As we previously indicated, [plaintiff] is mistaken in her contention that her underlying state law claim for [vicarious medical malpractice] is not preempted. [Plaintiff's] claim for emotional distress, like [her] other state law claims, is based upon [the MCO's] failure to expeditiously precertify payment for [her spouse's] surgery. We conclude that [plaintiff's] claim for emotional distress "relates to" [the MCOs'] administration of the [EBP] within the broad meaning of the ERISA preemption clause .... [and] is also preempted....

Id. However, this case may have jurisdictional flaws making its results potentially void. See infra Section I.I (discussing jurisdictional errors of the courts).

165. 59 F.3d 151 (10th Cir. 1995).

166. See id. at 155.

167. The appeals court noted "[ $\mathrm{t}] \mathrm{he}$ issue is whether the medical malpractice claim 'relates to' the [MCO] plan." Id. at 154. The court seemed to accept without comment the district court's analysis of the issue, see id., but both courts' decisions with regard to the applicability of ERISA's preemption provision may have been inappropriately made. It is apparent that the district court made some determinations as to the applicability of ERISA's preemption provision to the vicarious-liability claims against the MCO: "[T]he [district] Court concurs with the reasoning of the courts which have held that ERISA does not preempt a state law tort claim brought against a health maintenance organization premised upon vicarious liability and/or ostensible agency [under ERISA's preemption provision]." Schachter v. Pacificare of Oklahoma, 923 F. Supp. 1448, 1451 (N.D. Okla. 1995). Yet, this decision, and the accompanying decision of 


\section{Patient Injury Incentives}

the Seventh Circuit in Jass, that the relationship between the EBP, MCO, and plan participant did not invoke ERISA's preemption provision and thus plaintiff's indirect-liability claims against the MCO were not preempted by ERISA's preemption provision. The court concluded that "[j]ust as ERISA does not preempt the malpractice claim against the doctor, it should not preempt the vicarious liability claim against the HMO if the HMO has held out the doctor as its agent."168 After deciding this issue, the court concluded that the district court's order to remand to the state court was appropriate. ${ }^{169}$

\section{Jurisdictional Confusion}

The issue of whether indirect-liability claims against ERISA MCOs are preempted can only be answered with a definite maybe. As the last Section showed, federal courts of appeals that have addressed whether the statute's preemption provision preempts indirect-liability claims against MCOs have seemingly come to opposite conclusions. Federal district courts have issued similar rulings, with a majority reaching the conclusion of non-preemption. ${ }^{170}$ However, a very serious problem attends

the court of appeals on the merits of this conclusion, should arguably never have been reached due to jurisdictional defects not discussed or noticed by the courts. See infra Section I.I for a fuller discussion of the jurisdictional difficulties experienced by this and other courts.

168. Pacificare of Oklahoma, 59 F.3d at 155.

169. The court acknowledged, however, that courts are not unanimous on the question. "Courts reaching the opposite conclusion, generally, have reasoned that a vicarious liability malpractice claim concerns the delivery of benefits under the plan and the claim requires examination of the plan to determine obligations owed under the plan and the relationship between the plan and plan doctors." Id. at 154-55.

170. Some district courts have held that ERISA preempts vicarious-liability claims against MCOs. See, e.g., Clark v. Humana Kansas City, 975 F. Supp. 1283, 1286-87 (D. Kan. 1997); Pomeroy v. Johns Hopkins Medical Servs., 868 F. Supp. 110, 111-14 (D. Md. 1994); BaileyGates v. Aetna Life Ins. Co., 890 F. Supp. 73, 76-79 (D. Conn. 1994); Butler v. Wu, 853 F. Supp. 125, 128-30 (D.N.J. 1994); Nealy v. U.S. Healthcare HMO, 844 F. Supp. 966, 970-75 (S.D.N.Y. 1994); Ricci v. Gooberman, 840 F. Supp. 316, 317-18 (D.N.J. 1993); Diaz v. Texas Health Enterprises, 822 F. Supp. 1258, 1261-62 (W.D. Tex. 1993); Craft v. Northbrook Life Ins. Co., 813 F. Supp. 464, 469-70 (S.D. Miss. 1993); Altieri v. CIGNA Dental Health, 753 F. Supp. 61, 63-65 (D. Conn. 1990).

Many more district courts have held that ERISA does not preempt vicarious-liability claims against MCOs. See, e.g., Newton v. Tavani, 962 F. Supp. 45, 46-48 (D.N.J. 1997); Dykema v. King, 959 F. Supp. 736, $739-41$ (D.S.C. 1997); Santitoro v. Evans, 935 F. Supp. 733, 735-36 (E.D. N.C. 1996); Prihoda v. Shpritz, 914 F. Supp. 113, 116-18 (D. Md. 1996); Webb v. Gibson, No. 95C2084, 1995 WL 716640, at *3 (N.D. Ill. Nov. 30, 1995); Kusznir v. Lutheran Gen. Hosp., No. 95C1325, 1995 WL 404860, at *2 (N.D. Ill. May 31, 1995); Jackson v. Roseman, 878 F. Supp. 820, 823-26 (D. Md. 1995); Haas v. Group Health Plan, 875 F. Supp. 544, 547-49 (S.D. Ill. 1994); Dearmas v. Av-Med., Inc., 865 F. Supp. 816, 817-18 (S.D. Fla. 1994); Kearney v. U.S. Healthcare, 859 F. Supp. 182, 185-86 (E.D. Pa. 1994); Paterno v. Albuerne, 855 F. Supp. 1263, 1263-64 (S.D. Fla. 1994). State courts have also held that vicarious-liability claims are not preempted. See In re Estate of Frappier, 678 So. 2d 884, 886-87 (Fla. Dist. Ct. App. 1996); Nascimento v. 
these indirect-liability adjudications. In a great many of these cases, including those heard by federal circuit courts, courts are ruling on tenuous and erroneous jurisdictional grounds.

On the basis of standard federal civil procedure, federal courts have jurisdiction to hear a private litigation case based on two primary foundations: federal question jurisdiction and diversity jurisdiction. ${ }^{171}$ Federal question jurisdiction allows federal courts to hear a case when the plaintiff's claims "arise under the Constitution, treaties or laws of the United States."

Harvard Community Health Plan, Civ. A. No. 94-2534, MASS. LAWYERS WEEKLY, Oct. 6, 1997 (Mass. Sup. Ct. 1997); Tufino v. New York Hotel and Motel Trades Council, 646 N.Y.S.2d 799, 800-02 (N.Y. App. Div. 1996); Andujar v. Lenox Hill Hosp., 641 N.Y.S.2d 532, 532 (N.Y. App. Div. 1996).

For background material on ERISA preemption of vicarious-liability claims, see generally Laura H. Harshbarger, Note, ERISA Preemption Meets the Age of Managed Care: Toward a Comprehensive Social Policy, 47 SYRACUSE L. REV. 191 (1996) (arguing for a standard that ERISA does not preempt vicarious-liability claims against ERISA MCOs); Brooks Richardson, Comment, Health Care: ERISA Preemption and HMO Liability-A Fresh Look at ERISA Preemption in the Context of Subscriber Claims Against HMOs, 49 OKLA. L. REV. 677 (1996) (advocating a post-Travelers analysis of ERISA preemption on the basis of the term "benefits" rather than the statutory language of $\$ 514$ ).

171. More specifically, "the principal statutory provisions for jurisdiction of the federal district courts are those regarding diversity jurisdiction, 'general' federal question jurisdiction, 'special' federal question jurisdiction, admiralty, bankruptcy, and actions involving the United States as a party." FLEMING JAMES, JR. ET AL., CIVIL PROCEDURE $\$ 2.24$ (4th ed. 1992). Federal courts may exercise secondary jurisdiction under the concept of "supplemental jurisdiction," which encompasses the subcategories of ancillary jurisdiction, pendent claim jurisdiction, and pendent party jurisdiction. See $i d . \$ 2.28$. Supplemental jurisdiction has been codified at 28 U.S.C. $\$ 1367$, which provides in part:

[I]n any civil action of which the district courts have original jurisdiction, the district courts shall have supplemental jurisdiction over all other claims that are so related to claims in the action within such original jurisdiction that they form part of the same case or controversy under Article III of the United States Constitution. Such supplemental jurisdiction shall include claims that involve the joinder or intervention of additional parties.

28 U.S.C. $\$ 1367$ (a) (1994). In ERISA cases without complete diversity the federal courts do not have original jurisdiction except under section 502, the civil enforcement provision, and the defendant cannot remove and a district court cannot exercise jurisdiction over a complaint that does not on its face implicate federal law. Note, of course, that a federal court has jurisdiction to determine if it has jurisdiction to decide the case on the merits:

Jurisdiction ... is the power to hear and determine the controversy presented, in a given set of circumstances. A court has jurisdiction, in another use of the term, to examine the question whether that power is conferred upon it in the circumstances disclosed but if it finds such power is not granted it lacks jurisdiction of the subject matter and must refrain from any adjudication of rights in connection therewith.

In re NLRB, 304 U.S. 486, 494 (1938); see also 15A CHARLES ALAN WRIGHT ET AL., FEDERAL PRACTICE \& PROCEDURE $\$ 3903$ (2d ed. 1992 \& Supp. 1998) (stating that a court of appeals is required to note lack of jurisdiction of the district court and resolve jurisdictional issues of itself and the lower court).

172. 28 U.S.C. $\$ 1331$ (1994). 


\section{Patient Injury Incentives}

quires a reference to the well pleaded complaint rule, which indicates that a plaintiff's claim "arises under" federal law only if a federal claim is cognizable on the face of the complaint. ${ }^{173} \mathrm{~A}$ case can be removed from state to federal court only if this requirement is fulfilled. ${ }^{174}$ As indicated above, even the possibility of a federally based preemption defense is not sufficient to allow removal to federal court. ${ }^{175}$ Of course, the exception to this rule is a claim subject to the complete preemption doctrine, which indicates that despite the plaintiff's well pleaded complaint and the lack of any implication of federal law on its face, the state court action is recharacterized as a federal action amenable to removal. ${ }^{176}$ These jurisdictional details do not attend if the plaintiff brings a suit based on federal law alone, if the suit is brought on the basis of federal law with supplemental or concurrent jurisdiction over state-law claims, or if the parties qualify for federal court jurisdiction on the basis of diversity. ${ }^{17}$

However, "[a federal] district court must remand a case removed from a state court '[i]f at any time before final judgment it appears that [the federal court] lacks subject matter jurisdiction." 178 Indeed, "[w]here a case has been improperly removed and the Court has no subject matter jurisdiction, the Court must remand the case sua sponte to the state court where it originated, pursuant to 28 U.S.C. $\$ 1447$ (c)." ${ }^{179}$ This jurisdictional

173. See Franchise Tax Bd. v. Construction Laborers Vacation Trust, 463 U.S. 1, 9-12 (1983); see also American Fire \& Cas. Co. v. Finn, 341 U.S. 6, 14 (1950) (stating that the plaintiff's pleading controls the assessment of the jurisdictional basis of the federal court).

174. Of course, removal to federal court is also appropriate if the requirements for diversity of the parties are met. See 28 U.S.C. $\$ 1441$ (c) (1994).

175. See supra notes 122-123 and accompanying text (discussing the well pleaded complaint rule); see also Gully v. First Nat'l Bank, 299 U.S. 109, 115-18 (1936).

176. See supra notes $124-125$ and accompanying text (discussing the complete preemption doctrine).

177. See JAMES ET AL., supra note 171, $\$ \S 2.24-.26, .28$; see also Rivet v. Regions Bank, 118 S. Ct. 981 (1998) (stating that claim preclusion by reason of a prior federal judgment is a defensive plea that does not provide a basis for removal jurisdiction).

178. Newton v. Tavani, 962 F. Supp. 45, 46 (D.N.J. 1997) (second and third alterations in the original) (quoting 28 U.S.C. \$ 1447(b)). According to the Federal Rules of Civil Procedure, "[w] henever it appears by suggestion of the parties or otherwise that the court lacks jurisdiction of the subject matter, the court shall dismiss the action." FED. R. CIV. P. 12(h)(3); see also Louisville \& Nashville R.R. Co. v. Mottley, 211 U.S. 149 (1908) (remanding a federal case for lack of jurisdiction and noting that a federal defense is not adequate to confer federal jurisdiction); Minnesota v. Northern Sec. Co., 194 U.S. 48 (1904) (reversing and remanding federal circuit and district court adjudications to state court due to lack of federal jurisdiction).

179. Morrison v. Seafarers Int'I Union, 954 F. Supp. 55, 56 (E.D.N.Y. 1996) (emphasis added) (citing S\&H Grossinger, Inc. v. Hotel and Restaurant Employees and Bartenders Int'l Union Local 343, 272 F. Supp. 25, 27 (S.D.N.Y. 1967)). The removal rules under section 1447 relating to remand for want of subject matter jurisdiction are as follows:

(c)... . If at any time before final judgment it appears that the district court lacks subject matter jurisdiction, the case shall be remanded. An order remanding the case may require payment of just costs and any actual expenses, including attorney fees, in- 
assessment is the first issue a court must consider before inquiring into the merits of the case, without regard to any "waiver" by the parties. ${ }^{180} \mathrm{~A}$ party may reassert a jurisdictional defect based on equitable concerns even after final adjudication. ${ }^{181}$ In sum:

curred as a result of the removal. A certified copy of the order of remand shall be mailed by the clerk to the clerk of the State court. The State court may thereupon proceed with such case.

28 U.S.C.A. $\$ 1447$ (c) (West Supp. 1998). Note also that consolidation with a jurisdictionally proper case or an agreement by the parties cannot cure jurisdictional infirmities. See Reich v. Local 30, International Brotherhood of Teamsters, 6 F.3d 978, 982 n.5 (3d Cir. 1993) (stating that the parties to an action cannot waive subject matter jurisdiction requirements by consenting to court's jurisdiction); McKenzie v. United States, 678 F.2d 571, 574 (5th Cir. 1982) (finding that the consolidation of a jurisdictionally deficient claim with a jurisdictionally proper claim does not cure jurisdictional defects); Hoyt v. Edge, No. CIV.A.97-3631, 1997 WL 356324, at *1 (E.D. Pa. June 20, 1997) (stating that the lack of subject matter jurisdiction cannot be waived).

180. See, e.g., United States v. Corrick, 298 U.S. 435,440 (1936) ("[A]ppellants did not raise the question of jurisdiction at the hearing below[, b]ut the lack of jurisdiction of a federal court touching the subject-matter cannot be waived ... and the District Court should, therefore, have declined sua sponte to proceed with the case." (citations omitted)); McNutt v. General Motors Acceptance Corp., 298 U.S. 178, 189 (1936) (stating that a federal district court is authorized to make an inquiry into its jurisdictional authority to hear a case); Chicago, Burlington, \& Quincy Ry. Co. v. Willard, 220 U.S. 413, 419 (1911) ("It is firmly established . . . that in every case pending in an appellate Federal court of the United States, the inquiry must always be whether, under the Constitution and laws of the United States, that court or the court of original jurisdiction could take cognizance of the case."); Thomas v. Board of Trustees, 195 U.S. 207, 211 (1904) (noting that a federal court with jurisdiction based on diversity must make an assessment as to whether the record shows such diversity, even if the parties do not call attention to any defect); Cameron v. Hodges, 127 U.S. 322, 326 (1888) (holding that a federal court that finds a lack of federal jurisdiction must remand the case to the state court from which it was removed). This rule is fundamental.

[T]he rule, springing from the nature and limits of the judicial power of the United States, is inflexible and without exception which requires this court, of its own motion, to deny its own jurisdiction, and, in the exercise of its appellate power, that of all other courts of the United States, in all cases where such jurisdiction does not affirmatively appear in the record on which, in the exercise of that power, it is called to act. On every writ of error or appeal the first and fundamental question is that of jurisdiction, first, of this court, and then of the court from which the record comes. This question the court is bound to ask and answer for itself, even when not otherwise suggested, and without respect to the relation of the parties to it.

Mansfield, Coldwater \& Lake Michigan Ry. Co. v. Swan, 111 U.S. 379, 382 (1884) (emphasis added); see also American Fire \& Cas. Co. v. Finn, 341 U.S. 6, 18 (1950) (finding that to allow a federal district court to enter judgment in an inappropriately removed state court case "would by the act of the parties work a wrongful extension of federal jurisdiction and give district courts power the Congress has denied them"); U.S. v. Griffin, 303 U.S. 226, 229 (1938) (noting that a federal court's lack of jurisdiction cannot be waived by parties and that the bill must be dismissed if the federal court lacks jurisdiction).

181. Equitable obstacles such as laches do not cure the jurisdictional defect:

When it appears that the case is not within the jurisdiction of the court, we find nothing in the conduct of the parties to support the suggestion of laches. If it be true that the statute of limitations would prevent the beginning of a new action in state court, that fact cannot confer jurisdiction upon a court of the United States, in the absence of a showing of diverse citizenship. 


\section{Patient Injury Incentives}

Removal jurisdiction is the threshold question. If removal was improper, there is no federal jurisdiction and the matter must be promptly remanded to state court without consideration of the pending motion to dismiss.... The jurisdictional principles governing removal are well-established. The threshold requirement is that the complaint must fall within the "original jurisdiction" of the federal district court. 28 U.S.C. $\$ 1441$ (a). In other words, an action may be removed to federal court only if it might have been filed there originally. So, where, as here, there is no diversity of citizenship between the parties, the propriety of removal depends on the existence of federal question jurisdiction, i.e., whether any of the plaintiffs' claims "arise under" federal law. 28 U.S.C.A. $\$ 1331$

Whether any of plaintiffs' claims "arise under" federal law is determined by application of the "well-pleaded complaint rule."... [A] defendant cannot convert a plaintiff's state claim into a federal question solely on the basis of an asserted federal defense. Even the defense of preemption is insufficient to permit removal to federal court. In other words, "[t]he [well-pleaded complaint] rule makes the plaintiff the master of the claims; he or she may avoid federal jurisdiction by exclusive reliance on state law." ${ }^{182}$

These directions for the federal court are important " [b]ecause lack of jurisdiction would make any decree in the case void and the continuation of the litigation in the federal court futile[;] [hence,] the removal statute should be strictly construed and all doubts resolved in favor of remand.",183

Gilbert v. David, 235 U.S. 561, 568 (1915). Further:

[T] $T$ he conclusion seems inescapable that the duty devolves upon the court 'at any time' the jurisdictional question is presented to proceed no further until that question is determined. It can not be conferred by agreement, consent or collusion of the parties, whether contained in their pleadings or otherwise, and a party can not be precluded from raising the question by any form of laches, waiver or estoppel.

Page v. Wright, 116 F.2d 449, 453 (7th Cir. 1940); see also Goldstone v. Payne, 94 F.2d 855, 857 (2d Cir. 1938) ("[A] want of jurisdiction cannot be waived by pleadings or any other form of consent-not even by going to trial.").

182. Lancaster v. Kaiser Found. Health Plan, 958 F. Supp. 1137, 1141-43 (E.D. Va. 1997) (footnotes omitted) (quoting Caterpillar, Inc. v. Williams, 482 U.S. 386, 392 (1987)).

183. Brown v. Francis, 75 F.3d 860, 864-65 (3d Cir. 1996) (emphasis added) (citations omitted) (quoting Abels v. State Farm Fire \& Cas. Co., 770 F.2d 26, 29 (3d Cir. 1985)); see also Shamrock Oil \& Gas Corp. v. Sheets, 313 U.S. 100, $108-09$ (1941) (discussing the requirement that removal statutes be construed strictly). It is reversible error for a circuit court of appeals not to remand a case after erroneously assuming jurisdiction. See Mansfield, Coldwater \& Lake Michigan Ry. Co. v. Swan, 111 U.S. 379, 380-01 (1884); see also 5 AM. JUR. 2D Appellate Review $\$ \$ 14$ (1995) ("Where the judgment below was rendered without jurisdiction, an appellate court must ordinarily reverse and remand for dismissal. Indeed, such a judgment cannot be reversed on the merits, because the decision below is void." (footnotes omitted)); 20 AM. JUR. 2D Courts $\$ 65$ (1995) ("[P]roceedings conducted or decisions made by a court are legally void when there is an absence of jurisdiction over the subject matter."). A narrow "futility exception" to this general concept has been noted: "In the case of improper removal, the federal court has jurisdiction only if the complaint is so defective that it fails to state a cause of action under either state or federal law. In that event it would be wasteful to remand the case to state court where it 
ERISA cases implicate these important jurisdictional issues quite often. If, as is typical, an aggrieved ERISA beneficiary brings state-law claims against an ERISA MCO in state court, the MCO will as a matter of course remove that action to federal court. The federal court in these circumstances must first assess whether it has jurisdiction to hear the case. If the federal court finds that the claims are within the scope of ERISA's civil enforcement provision, then they necessarily present a federal issue and the federal court clearly has jurisdiction under the complete preemption doctrine. ${ }^{184}$ Otherwise, absent some other basis for jurisdiction such as diversity or another independent federal claim, the federal court must remand the case to the state court for adjudication. ${ }^{185}$ This is true even if there is a basis for the MCO to defend against the plaintiff's claims using ERISA's preemption provision: A federal conflict preemption defense is simply not a suitable basis for federal jurisdiction. ${ }^{186}$

Hence, an ERISA beneficiary's state court action invoking solely state-law claims can be removed to federal court and heard only if that court determines that the claims are within ERISA's civil enforcement provision. ${ }^{187}$ If this condition is not met, the court must return the case to

would face inevitable dismissal. The federal court has jurisdiction to entertain and decide a motion to dismiss." Prihoda v. Shpritz, 914 F. Supp. 113, 117 n.9 (D. Md. 1996) (citing Childers v. C \& P Tel. Co., 881 F.2d 1259, 1262 (4th Cir. 1989)); see also 14C CHARLES ALAN WRIGHT ET AL., FEDERAL PRACTICE \& PROCEDURE \& 3739 (3d ed. 1998) (discussing the futility exception and the requirement that federal courts remand if the case is outside of its jurisdiction). Without jurisdiction, the court would not even have the power to award costs. See Smyth v. Asphalt Belt Ry., 267 U.S. 326 (1925). However, at least one treatise indicates that some courts would hold that parties who do not object to a court's subject matter jurisdiction would be bound by its judgment. See 13A Charles AlaN WRight ET AL., Federal Practice \& Procedure $\S 3536$ (2d ed. 1984 \& Supp. 1998); see also Chicot County Drainage Dist. v. Baxter State Bank, 308 U.S. 371 (1940) (stating that assertions of subject matter jurisdiction by federal courts cannot be attacked collaterally). However, this would leave the decision without precedential value and would seem to make it an "advisory opinion," which is barred by Article III of the Constitution.

184. See Lancaster, 958 F. Supp. at 1145 ("These principles, applied here, require an examination of plaintiffs' claims. If any one of the claims is completely preempted [under ERISA's civil enforcement provision], then removal of the entire complaint is proper....").

185. See supra note 178 and accompanying text.

186. See Jass v. Prudential Health Care Plan, 88 F.3d 1482, 1488 (7th Cir. 1996) ("A claim ... subject to 'conflict preemption under $\S 514$ (a) [ERISA's preemption provision] ... is not subject to the jurisdictional doctrine of 'complete preemption' under $\S 502(\mathrm{a})$ [ERISA's civil enforcement provision].... Therefore, the district court erred in concluding that it had federal question jurisdiction over these claims ... based on ERISA preemption."); see also supra notes 122-125 and accompanying text (discussing conflict versus complete preemption).

187. See Prihoda v. Shpritz, 914 F. Supp. 113, 117 (D. Md. 1996). As the Prihoda court stated:

When the doctrine of complete preemption is inapplicable, but the plaintiff's state law claim is arguably preempted under $\$ 514(\mathrm{a})$ [ERISA's preemption provision], the district court, being without removal jurisdiction, cannot resolve the dispute regarding the 
the state court whence it came. The federal district court cannot decide issues of plaintiff's indirect-liability claims and whether they are preempted by ERISA's preemption provision because the federal court does not have jurisdiction. Any decision made by a federal court without jurisdiction on these matters is void. ${ }^{18 s}$

Federal courts, however, have ignored these well established, fundamental procedural rules in a great number of ERISA cases, including some key ones. For example, in Schachter $v$. Pacificare of Oklahoma, ${ }^{189}$ the precursor case to the Tenth Circuit case of Pacificare of Oklahoma $v$. Burrage ${ }^{190}$ it appears that the federal district court inappropriately exercised jurisdiction over the case. The plaintiffs originally brought suit in state court, pleading only the state-law causes of action of vicarious liability of the ERISA MCO, fraud, and loss of consortium. ${ }^{191}$ Defendants removed "on the ground that [the plaintiff's] state law claims against [defendant MCO] were preempted by the Employee Retirement Income Security Act of 1974" and moved for summary judgment. ${ }^{192}$ The district court did not assess whether it had complete preemption jurisdiction under the civil enforcement provision. Further, the court did not claim, and the decision does not reveal, any other independent jurisdictional authority to hear the case, such as supplemental or diversity jurisdiction. Rather than determine its jurisdiction, the court began by making rulings on the merits. Indeed, the very provision it should have been assessing for jurisdictional purposes was assessed instead to hold that the plaintiff's vicarious-liability claims against the $\mathrm{MCO}$ were not preempted:

A medical malpractice action, such as that at issue in the instant case, does not involve a claim for benefits, a claim to enforce rights under the benefit plan or a claim challenging administration of the benefit plan [under ERISA's civil enforcement provision]. It simply involves a claim that the de-

preemption defense. It lacks power to do anything other than remand to the state court where the preemption issue can be addressed and resolved subject to possible Supreme Court review.

Id.

188. See supra note 183 and accompanying text (discussing effect of lack of jurisdiction). Note that "when a case is improperly removed but is tried to judgment on the merits without objection, a party waives his right to later raise the issue of lack of subject matter jurisdiction at the time of the removal' [only] if the action could have been brought initially in federal court." Tolton v. American Biodyne, 48 F.3d 937, 941 (6th Cir. 1995) (emphasis added) (citations omitted).

189. 923 F. Supp. 1448 (N.D. Okla. 1995).

190. 59 F.3d 151 (10th Cir. 1995). For the previous discussion of this decision, see supra notes 165-169 and accompanying text.

191. See Schachter, 923 F. Supp. at 1450.

192. See id. 
ceased received allegedly negligent treatment from a doctor who was "held out" by the health maintenance organization as its agent. ${ }^{193}$

The court then continued on its erroneous path by applying the statute's preemption provision to the plaintiff's indirect-liability claims.

[C]ourts have concluded that a vicarious liability and/or ostensible agency claim against a health maintenance organization is not sufficiently "related to" ERISA so as to warrant preemption ... [and concerns ERISA in] "too tenuous, remote, or peripheral a manner to warrant a finding that the law 'relates to' the plan.",194

The court then reviewed the plaintiff's fraud claim, and again failed to indicate its jurisdictional authority to assess the issue. The court, in deciding the issue on the merits, simply agreed with the MCO that the fraud claim "'relates to' the employee benefit plan and is preempted by [the preemption provision] of ERISA." ${ }^{195}$ The court granted summary judgment to the defendant MCO on the plaintiff's fraud claim. ${ }^{196}$

Finally, the court held that the plaintiff's loss-of-consortium claim was not preempted, again relying only on ERISA's preemption provision without stating its jurisdictional authority to make such an assessment. The court ruled that "the loss of consortium claim does not relate to the employee benefit plan and is [therefore] not preempted by ERISA."197 It then indicated that it would not exercise supplemental jurisdiction over the state-law claims and remanded the case.

The string of holdings in the case is inappropriate. Indeed, as was just noted, the court expressly did not exercise supplemental or other jurisdiction over plaintiff's state-law claims. ${ }^{199}$ Thus, after holding that ERISA's civil enforcement provision did not apply to plaintiff's vicarious-liability claim, the court should not have decided on the merits the applicability of ERISA's preemption provision to the claim, but rather should have remanded the issue. Similarly, the court did not determine whether plaintiff's fraud and loss-of-consortium claims fell within ERISA's civil enforcement provision; instead, the court skipped directly and inappropriately to a determination on the merits as to whether the claims fell within ERISA's preemption provision. Since the court did not have jurisdiction, that determination was the province of the state court from which the case was improperly removed. ${ }^{200}$

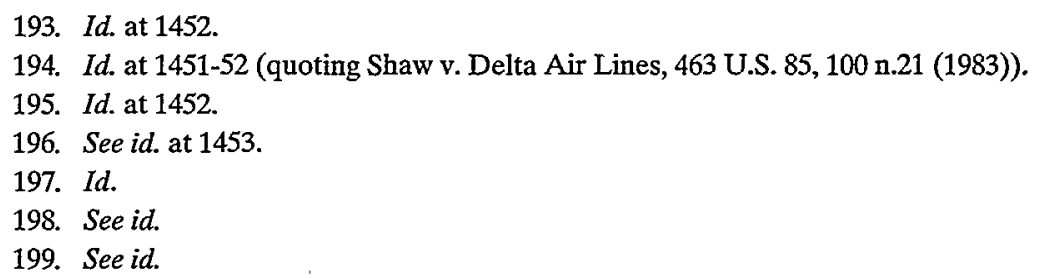

200. Indeed, the federal district court appeared to confuse conflict preemption, involving 
The Tenth Circuit Court of Appeals compounded the district court's error when it decided the defendant MCO's appeal for a writ of mandamus. The court of appeals noted that "[m]andamus 'will issue only in those exceptional cases where the inferior court has acted wholly without jurisdiction or so clearly abused its discretion as to constitute a judicial usurpation of power," ${ }^{201}$ but did not remedy this exact error of the district court. Indeed, the court of appeals reviewed de novo the issue of whether ERISA preempts the state-law claims presented to the district court. Instead, however, of fulfilling its obligation to determine at the outset its jurisdiction and the lower court's jurisdiction, ${ }^{202}$ i.e., whether the claims fell within ERISA's civil enforcement provision, the court of appeals skipped to whether ERISA's preemption provision preempted the claims, i.e., did the claims "relate to" the EBP. ${ }^{203}$ As we have seen, the federal court, absent other federal jurisdictional bases, cannot reach the issue of ERISA preemption under the statute's preemption provision before it establishes appropriate jurisdictional authority under the complete preemption doctrine or in some other appropriate manner, such as diversity. ${ }^{204}$ Thus, the decisions of both the federal district court and court of appeals regarding the preemptive nature of ERISA on these state-law claims, particularly the important issue of ERISA preemption of indirectliability claims, are presumably void on jurisdictional grounds ${ }^{205}$ - a fact very significant as the Tenth Circuit's decision is one of only two conflicting court of appeals opinions on the matter of indirect-liability preemption. ${ }^{206}$

Unfortunately, other federal courts of appeals have also fallen prey to this jurisdictional confusion. For example, the Third Circuit, in Dowden

ERISA's preemption provision, and complete preemption, involving ERISA's civil enforcement provision. See id.

201. Pacificare of Oklahoma v. Burrage, 59 F.3d 151, 153 (10th Cir. 1995) (citing In re Kaiser Steel Corp., 911 F.2d 380, 387 (10th Cir. 1990)).

202. See supra notes $180-183$ and accompanying text (discussing jurisdictional obligations of courts).

203. See Pacificare of Oklahoma, 59 F.3d at 154 ("The issue is whether the medical malpractice claim 'relates to' the [EBP].")

204. See 28 U.S.C. $\S \S 1332,1441$ (1994), 29 U.S.C.A. $\$ 1144$ (West 1985 \& Supp. 1998); see also Blanke v. Lincoln Nat'l Corp., No. Civ. A 97-3026, 1997 WL 786225 (E.D. La. Dec. 18, 1997); Lancaster v. Kaiser Foundation Health Plan, 958 F. Supp. 1137 (E.D. Va. 1997).

205. See supra note 183 and accompanying text. The Tenth Circuit has once again made this error. See Prudential Health Care Plan v. Lewis, No. 95-6255, 1996 WL 77018 (10th Cir. Feb. 21, 1996) (unpublished decision) (relying on Pacificare of Oklahoma to affirm the district court's post-removal summary judgment for the plaintiff, ruling that ERISA's preemption provision does not preempt state-law claims of vicarious liability).

206. Recall that in the other appellate indirect-liability case, Jass v. Prudential Health Care Plan, 88 F.3d 1482 (7th Cir. 1996), the court had diversity jurisdiction. See supra note 151 and accompanying text. 
v. Blue Cross \& Blue Shield of Texas, ${ }^{207}$ indicated incorrectly that "[a] defendant may remove a case [to federal court] on grounds that the plaintiff has asserted a claim preempted by $\$ 514$ [ERISA's preemption provision]. ${ }^{208}$ Here the court, like in the Pacificare cases, has confused complete preemption, which confers federal jurisdiction, with conflict preemption, which is merely a federal preemption defense and not an independent basis for conferring jurisdiction on a federal court.

The Fifth Circuit Court of Appeals has also made this jurisdictional error. In Rodriguez $v$. Pacificare of Texas, ${ }^{209}$ the court erred when it affirmed the district court's judgment that the plaintiff's cause of action was preempted by ERISA. Here, an employee brought an action against his ERISA MCO in state court for not providing him with what he considered to be an appropriate referral. ${ }^{210}$ After removal by the defendant and summary judgment against the plaintiff, the plaintiff asserted in his appeal that the district court did not have jurisdiction to hear the case. However, the Fifth Circuit held for the defendant: "While the claims in the present case are couched in terms of state law, the cause of action against [the $\mathrm{MCO}] .$. is preempted by the Employee Retirement Income Security Act." ${ }^{211}$ The court erred when discussing its jurisdictional bases:

An exception to the well pleaded complaint rule has been carved out for those areas in which Congress "so completely pre-empt[ed] a particular area that any civil complaint raising this select group of claims is necessarily federal in character." ... Such a niche has been carved out by Congress for claims for benefits brought by participants and beneficiaries of ERISAregulated employee benefit plans. See 29 U.S.C.A. $\$ 1144(a)$ [ERISA's preemption provision]....

The claims against [the $\mathrm{MCO}$ ] supported removal based on the existence of a federal question, albeit one not apparent on the face of [the plaintiff's] complaint. $^{212}$

207. 126 F.3d 641 (5th Cir. 1997).

208. Id. at 642-43 (emphasis added) (citing Metropolitan Life Ins. Co. v. Taylor, 481 U.S. $58,66(1987)$ ). The court of appeals incorrectly relied upon Metropolitan Life, in which the Supreme Court only held that claims that invoked section 502, ERISA's civil enforcement provision, were removable. See Metropolitan Life Ins. Co., 481 U.S. at 66.

209. 980 F.2d 1014 (5th Cir. 1993).

210. Arguably, this denial of an appropriate referral is within the scope of section 502, thus giving the court jurisdiction over the case. However, the court's rationale and discussion do not reflect an understanding of the jurisdictional issues. See infra notes 211-213 and accompanying text (addressing the court's ERISA discussion).

211. Rodriguez, 980 F.2d at 1016-17 (citing the statute's preemption provision).

212. Id. at 1017-18 (quoting Metropolitan Life, 481 U.S. at 63-64) (emphasis added). Indeed, the court amazingly quotes Pilot Life Ins. Co., which is the case that indicated that 
And indeed, the Court went on to simply review whether the plaintiff's claims "relate to" the EBP on its way to affirming the district court's judgment. $^{213}$

Similarly, the Eighth Circuit Court of Appeals erred in Wilson $v$. Zoellner $^{214}$ by not remanding a state-law cause of action for lack of jurisdiction. In this case, an employee brought suit against an insurance agent for negligently misrepresenting the scope of benefits of an ERISA health policy. The employee plaintiff brought her tort suit in state court and the insurance agent removed the case to federal district court. ${ }^{215}$ The federal district court exercised jurisdiction over the case and granted summary judgment for the defendant, holding that the negligent misrepresentation claim was preempted by ERISA's preemption provision. ${ }^{216}$ The federal district court inappropriately decided the case on the merits instead of remanding the case to state court. Once again, a court of appeals compounded the error, stating first that it would "review the District Court's decision on ERISA preemption de novo because it is a question of federal law involving statutory interpretation." ${ }^{217}$ But the primary concern at the outset for the court of appeals should have been whether the district court had jurisdiction to hear the case. The defendant was asserting a federal conflict preemption defense which does not confer jurisdiction on the federal court. Thus, on de novo review, the court of appeals should have vacated the lower court's decision on the merits due to lack of jurisdiction and directed that the case be remanded to state court for adjudication of the ERISA conflict preemption question and the state-law claims. Instead, the court of appeals decided on the merits that ERISA's

ERISA's civil enforcement provision establishes federal jurisdiction. See id. ("Congressional intention is clear "that all suits brought by beneficiaries asserting improper processing of claims under ERISA-regulated plans be treated as federal questions governed by [ERISA's civil enforcement mechanisms]." (emphasis added) (quoting Pilot Life Ins. Co. v. Dedeaux, 481 U.S. 41, 55-56 (1987))).

213. "[The plaintiff's] state law claims, at bottom, result from dissatisfaction over [the MCO's] handling of his medical claims. Consequently, his state law causes of action are sufficiently related to the employee benefit plan ... to be preempted." Id. at 1017 (quotation omitted).

214. 114 F.3d 713 (8th Cir. 1997).

215. See id. at 715.

216. See id. Although this holding was reversed by the court of appeals, note that tortious misrepresentation is not uniformly considered outside the reaches of ERISA preemption. See, e.g., Carlo v. Reed Rolled Thread Die Co., 49 F.3d 790, 793 (1st Cir. 1995) (holding that negligent misrepresentation claims are preempted by ERISA).

217. Wilson, 114 F.3d at 715 (quoting In Home Health v. Prudential Ins. Co., 101 F.3d 600, 604 (8th Cir. 1996)). Indeed, in In Home Health, the Eighth Circuit Court of Appeals appears to have made the same error of inappropriately exercising jurisdiction when it determined that conflict preemption existed and assumed that such preemption was the basis for federal jurisdiction. See In Home Health, 101 F.3d at 604-07. 
preemption provision did not preempt a state-law tort claim of negligent misrepresentation. ${ }^{218}$

The Ninth Circuit may also have fallen the trap of jurisdictional error. In Ellison v. Spectrastar, an unpublished opinion, ${ }^{219}$ the plaintiff's wrongful death, negligence, fraud, and breach-of-contract claims were brought in state court, and the defendant removed to federal district court. The district court granted summary judgment to the defendant, indicating that the plaintiff's state-law claims were preempted by ERISA. ${ }^{220}$ The plaintiff appealed. Although the court of appeals did not indicate specifically which particular provision of ERISA was the basis of the district court's decision, it is most likely that the district court based its holding on ERISA's preemption provision because this is the only provision that the court of appeals discusses or cites. The court of appeals reviewed the lower court's determination de novo and affirmed the grant of summary judgment on the basis of the statute's preemption provision, ${ }^{221}$ erroneously exercising jurisdiction and affirming the district court's earlier incorrect exercise of jurisdiction.

Many other federal district courts have inappropriately taken jurisdiction and decided issues on ERISA matters. In the important area of indirect-liability claims, the district court in Ray v. Value Behavioral Health ${ }^{222}$ decided that vicarious-liability claims are not preempted by ERISA's preemption provision. ${ }^{23}$ In the case, the plaintiff took the well trodden path and brought her state-law claims in state court. The defendant MCO removed to federal district court. The court, without any discussion of jurisdictional authority, accepted the case and held that vicarious-liability claims against the MCO did not relate to ERISA under the statute's preemption provision. ${ }^{224}$

Similarly, in Yanez $v$. Humana Medical Plan, ${ }^{225}$ the federal district court, after the plaintiff's state-law claims of direct and vicarious negligence against the ERISA MCO were filed in state court and removed by the MCO, held that "tort actions that seek to hold defendant health maintenance organizations vicariously liable for medical malpractice are

218. See Wilson, 114 F.3d. at 721-22.

219. No. 94-56483, 1996 WL 368746 , at *1 (9th Cir. July 2, 1996).

220. See id.

221. See id. at $* 3$.

222. 967 F. Supp. 417 (D. Nev. 1997).

223. See id. at 424 . Ray filed her state court complaint alleging negligence by a professional counselor, breach of fiduciary duty, intentional infliction of emotional distress, negligent infliction of emotional distress, and invasion of privacy against the psychology provider and respondiat superior claims for these actions against the MCO. See id. at 419.

224. See id. at 423.

225. 969 F. Supp. 1314 (S.D. Fla. 1997). 
not preempted by ERISA['s preemption provision]."226 The court then remanded the case to state court. Once again, the federal district court did not explicate the basis of its jurisdiction over the case or how it could reach the issue of conflict preemption as applied to the plaintiff's statelaw claims.

Thus, the refrain from all these cases is clear: Federal courts seem to believe that state-law claims pleaded in state court are removable to federal court simply if there is ERISA conflict preemption. In the myriad of cases in which this has occurred, the state court was precluded from making its rightful determination of whether ERISA's preemption provision preempts the particular state-law claims brought by the plaintiff. The problem, unfortunately, appears ubiquitous; a very large number of federal district courts have made these jurisdiction errors, ${ }^{227}$ making all of

226. Id . at 1316 .

227. A sampling of the plethora of federal district court cases that make this jurisdictional error follows: In Newton v. Tavani, 962 F. Supp. 45 (D.N.J. 1997), the court confused the complete preemption ERISA section with the conflict preemption section: "[T]he complete preemption doctrine applies to state law causes of action falling within the scope of ERISA's civil enforcement provisions, as defined by 29 U.S.C.A. $\$ 1144$ (a) . . . [which] "shall supersede any and all state laws' ...." Id. at 46-47 (quoting 29 U.S.C. \$ 1144(a) (1994)). Of course, 29 U.S.C. \$ 1144(a) is ERISA's preemption provision, not the civil enforcement provision, and only the latter confers subject matter jurisdiction on the district court. In Schwartz v. FHP International Corp., 947 F. Supp. 1354 (D. Ariz. 1996), the court erred in indicating that "[ $t]$ o meet its burden of establishing that federal [subject matter] jurisdiction is appropriate under the complete preemption doctrine, Defendants must show: (1) that Plaintiffs' health insurance plan was an 'employee benefit plan' within the meaning of [ERISA]; and (2) that Plaintiffs' claims arise out of state laws that 'relate to' the ERISA plan." Id. at 1358 (emphasis added). Again, this is an error confusing the requirements of conflict preemption, which does not confer federal jurisdiction, with those of complete preemption, which does. In Trapanotto v. Aetna Life Insurance Co.Aetna, No. 95-10704, 1996 WL 417519 (S.D.N.Y. July 25, 1996), the court held that state-law claims of breach of contract, fraud, and unfair trade practices brought in state court and removed by defendants to federal court were preempted by ERISA's preemption provision and then remanded the case back to state court. See id. In Cornett v. Aetna Life Insurance Co., 933 F. Supp. 641 (S.D. Tex. 1995), the court held that state-law claims of negligent misrepresentation, gross negligence, and deceptive trade practices brought in state court and removed by defendant to federal district court were preempted by ERISA's preemption provision. See id. at 645-47. In Murphy v. Wal-Mart Associates' Group Health Plan, 882 F. Supp. 95 (E.D. Tex. 1995), the court held that state-law claims of deceptive trade practice, breach of contract, bad faith, and medical malpractice brought in state court and removed to federal district court were preempted by ERISA's preemption provision and indicated to the plaintiffs that their only recourse is to sue under ERISA's civil enforcement provision. See id. at 98. In Jackson v. Roseman, 878 F. Supp. 820 (D. Md. 1995), the court indicated that adjudication of the plaintiff's state-law vicarious-liability claims, removed to federal court by an ERISA MCO, were contingent upon "whether [plaintiff's] state law claim of vicarious liability sufficiently 'relates to' his employment benefit plan in a way that requires preemption." Id. at 823. In Stroker v. Rubin, No. 94-5563, 1994 WL 719694 (E.D. Pa. Dec. 22, 1994), the court confused jurisdictional standards.

If this court finds any portion of the plaintiffs' complaint [alleging state law claims of medical malpractice, wrongful death, negligence, and vicarious liability against the 
these cases, including the court of appeals decisions, presumably void. ${ }^{22 *}$ Viewing these cases from a perspective that seeks to protect patients, it is important to note that most of the courts that have made these errors

ERISA MCO] to be preempted by ERISA and that the civil enforcement provisions of ERISA provide an appropriate remedy, then removal [to this federal court] ... will be proper.... Thus, the question to be determined by this court is whether the state laws in question 'relate to' plaintiffs' employment benefit plan [as indicated in ERISA's preemption provision] in such a way that necessitates preemption.

Id. at *5 (emphasis added). In Dearmas v. Av-Med, Inc., 865 F. Supp. 816 (S.D. Fla. 1994), the plaintiff's state-law claims of medical malpractice against an ERISA MCO through direct and vicarious liability were removed from state to federal court by defendants. The court held that the relevant inquiry was whether state-law claims "relate to" the EBP and that ERISA's preemption provision provided potential subject matter jurisdiction over case. See id. at 818. In Bailey-Gates v. Aetna Life Insurance Co., 890 F. Supp. 73 (D. Conn. 1994), the federal district court, after removal by an ERISA MCO, indicated that loss-of-consortium, reckless indifference, negligence, breach-of-contract, and other state-law claims were preempted by ERISA's preemption provision: "The sole issue presented is whether plaintiff's claims 'relate to' an employee benefit plan and are thus preempted by ERISA." See id. at 77 (emphasis added). In Kearney v. U.S. Healthcare, 859 F. Supp. 182 (E.D. Pa. 1994), the plaintiff's medical malpractice, negligence, misrepresentation, breach-of-contract, and vicarious-liability claims were removed to federal court and decided on an interpretation of ERISA's preemption provision that preempted all claims but vicarious liability. See id. In Burke v. Smithkline Bio-Science Laboratories, 858 F. Supp. 1181 (M.D. Fla. 1994), the federal court on removal held that a third-party beneficiary cause of action, but not a medical malpractice action, was preempted by ERISA's preemption provision. See id. In Paterno v. Albuerne, 855 F. Supp. 1263 (S.D. Fla. 1994), the federal court indicated that the issue of whether a medical malpractice case removed from state court should be remanded is contingent upon an analysis of jurisdiction based on ERISA's preemption provision. See id. The case of Smith v. HMO Great Lakes, 852 F. Supp. 669 (N.D. Ill. 1994), involved a medical malpractice claim against a physician and an ERISA HMO that was removed to the federal district court, which held that "plaintiffs' state law negligence claims against defendant HMO do not 'relate to an employee benefit plan,' and, are therefore, not preempted by ERISA .... and [that] the case should be remanded to state court for lack of federal subject matter jurisdiction." Id. at 672 (emphasis added). In Butler v. 'Wu, 853 F. Supp. 125 (D.N.J. 1994), the federal district court on removal found that vicarious-liability claims for a physician's alleged malpractice were preempted by ERISA's preemption provision. See id. In Lancaster v. Chandra, No. 93 C 2717, 1994 WL 33962 (N.D. Ill. Feb. 4, 1994), the federal court, after their removal from state court, evaluated state wrongful death and vicarious-liability claims against a physician and ERISA MCO under the preemption provision even though the defendant $M C O$ removed the case asserting federal jurisdiction under ERISA's civil enforcement provision. See id. In Ricci v. Gooberman, 840 F. Supp. 316 (D.N.J. 1993), the state law vicarious-liability claims against an ERISA MCO were held to be preempted by ERISA's preemption provision after being removed from state court to federal court by defendants. See id. In Elsesser v. Hospital of the Philadelphia College of Osteopathic Medicine, 802 F. Supp. 1286 (E.D. Pa. 1992), the federal court, after removal of the claims from state court by an ERISA $\mathrm{MCO}$, held on reconsideration that the plaintiff's vicarious-liability claims against the MCO were not preempted but that the direct-liability, misrepresentation, and breach-of-contract claims were preempted under the statute's preemption provision. See id. Finally, in Independence HMO v. Smith, 733 F. Supp. 983 (E.D. Pa. 1990), the federal court denied an ERISA MCO's motion for a preliminary injunction against its subscriber's vicarious-liability suit in state court, finding that the suit was not preempted by ERISA's preemption provision. See id. at 98889.

228. See supra note 183. 
held that ERISA's preemption provision does not preempt plaintiff's indirect-liability claims. ${ }^{229}$ Indeed, the only valid federal appellate decision on the indirect-liability question is the Jass decision of the Seventh Circuit holding that the claims are most likely preempted. ${ }^{230}$

\section{INDEPENDENT CONTRACTORS AND MANAGED CARE}

Part I has shown that ERISA has been quite effective in shielding MCOs from liability and has provided a clear incentive for them to deny care so as to avoid patient injury liability. Similarly, the Dukes quality-ofcare distinction, although a crack in the shield, is of uncertain status because the direct state-law claims against ERISA MCOs may be categorized as denial-of-benefits or negligent-administration causes of action and may thus be preempted under the statute's civil enforcement or preemption provisions. Furthermore, as a matter of incentives, Dukes reinforces the tendency for MCOs to deny care so as to avoid the "quality" basis for plaintiff's claims. The other avenue that has been crafted seems more promising: indirect-liability claims. But there appears to be a split of authority on the issue, and reliance on decisions that have held in plaintiff's favor may be significantly misplaced since many of these decisions are presumably void, including the one court of appeals decision that holds in favor of plaintiffs. ${ }^{231}$ Thus, jurisdictional confusion makes taking this road a very rough ride indeed.

Even by using the economist's tool and assuming these jurisdictional problems away, however, indirect claim survival against ERISA preemption may only be a moral victory. Once a plaintiff overcomes the hurdles of ERISA and survives summary judgment, he or she can finally obtain an adjudication of these indirect claims on their merits. But alas, beyond the ERISA shield, MCOs have a second legal protection against the slings and arrows of plaintiff suits: the common law of independent contractors.

When MCOs contract to obtain physician services for their subscribers, they almost universally use independent contractor physicians. ${ }^{232}$ This is not a new development; physicians have traditionally been considered independent contractors and have generally provided services as such. ${ }^{233}$

229. See supra notes 189-228 (reviewing courts that have inappropriately exercised jurisdiction in ERISA cases).

230. See Jass v. Prudential Health Care Plan, 88 F.3d 1482 (7th Cir. 1996); see also supra notes 147-163 and accompanying text (discussing Jass).

231. See Pacificare v. Burrage, 59 F.3d 151 (10th Cir. 1995); supra Section I.H (discussing indirect-liability claims).

232. See Liang, Deselection, supra note 46 , at $845-51$.

233. See, e.g., Huber v. Protestant Deaconess Hosp. Ass'n, 133 N.E.2d 864, 870 (Ind. Ct. App. 1957); Biddle v. Sartori Mem'l Hosp., 518 N.W.2d 795, 797 (Iowa 1994); Chase v. Inde- 
When the $\mathrm{MCO}$ provides physician services through this independent contractor methodology, two important legal consequences result. First, under traditional tort law, an employer is generally not liable for any injuries caused by the independent contractors with whom it contracts. ${ }^{234}$ The independent contractors shoulder all liability even if the payment scheme is wholly designed by the employer to induce a particular action or set of actions and the employer retains sole authority to authorize or deny care. ${ }^{235}$ Thus, as applied to the managed care context, MCOs are generally not responsible for injuries caused by their independent contractor physicians. ${ }^{236}$

Second, there is generally no good faith or public policy restraint placed on an employer when terminating an independent contractor. This is important because almost every, if not all, managed care contracts with independent contractor physicians contain a key provision: the termination-without-cause clause. These clauses typically allow either party to terminate the contract for any or no reason at all if the specified notice is given. ${ }^{237}$ Although employees are generally considered to be terminable at any time, they do have limited protection; they cannot be terminated in violation of public policy (e.g., for obeying statutory or common law, performing jury duty, etc.) or in bad faith (e.g., to avoid paying an employee an earned bonus). ${ }^{238}$ The physician as an employee would have some tenuous protection against employer termination, but the physician as independent contractor can generally be terminated for any reason, even in bad faith. ${ }^{239}$ Each of these legal consequences has important ramifications on the dynamics of healthcare delivery in the current managed care infrastructure.

pendent Practice Ass'n, 583 N.E.2d 251, 254 (Mass. App. Ct. 1991); Jones v. Philpott, 702 F. Supp. 1210 (W.D. Pa. 1988); see also Conroy W. Shum \& Bryan A. Liang, Tax Treatment of a New Animal: Health Care Providers Who are Neither Employees nor Independent Contractors, VA. TAX REV. (forthcoming 1999) (discussing the tax status of physicians as employees and independent contractors in a managed care environment).

234. See W. Page Keeton et Al., Prosser and Keeton on the LaW of TORTS $\$ 71$, 509-10 (5th ed. 1984).

235. See id.

236. In contrast, employers are liable for actions of their employees that are performed within the scope of their employment duties. Hence, if the MCO did directly employ physicians, it would generally be liable for the actions of its physician employees. See id.

237. See, e.g., Abrahamson v. NME Hosps., 241 Cal. Rptr. 396, 397 (Cal. Ct. App. 1987) ("VI. TERM AND TERMINATION.... B. Either party may terminate this agreement without cause upon ninety (90) days written notice to the other party and shall duly inform the Hospital's Governing Board of such termination."); Harper v. Healthsource, New Hampshire, 674 A.2d 962, 964 (N.H. 1996) ("2.02. Termination Without Cause. This Agreement may be terminated by either party without cause upon six (6) months prior written notice.").

238. See Liang, Deselection, supra note 46 , at 813-24.

239. See Abrahamson, 241 Cal. Rptr. at 399. 
Finally, there is yet another difficulty: A physician continues to be liable under traditional tort law regardless of whether or not he or she has contracted with an ERISA MCO. Physicians are therefore faced with severely conflicting incentives: limiting care may avoid deselection but increase the chance of patient injury and a liability suit; providing "too much" care may avoid patient injury but result in deselection.

\section{A. Independent Contractor Shield: More MCO Protection}

Even in cases in which the plaintiff has had his or her state-law vicarious-liability claim adjudicated favorably under ERISA and has managed to avoid both complete preemption and conflict preemption, "the vicarious liability crack in the shield of ERISA preemption is one of narrow applicability." ${ }^{240}$ This is true because, consistent with traditional hornbook tort law, ${ }^{241}$ virtually all cases have held that MCOs and other principals (for example, hospitals and ship owners) are not responsible for the actions of independent physician contractors. ${ }^{242}$ There is a stable body of independent contractor law as applied to managed care and indirectliability claims. For example, in Raglin v. HMO Illinois, ${ }^{243}$ the court held that neither the health insurer nor its HMO subsidiary could be held liable under a vicarious-liability theory for negligent treatment by its independent contractor physicians. Raglin obtained her healthcare services

240. Andrews-Clarke v. Travelers Ins. Co., 984 F. Supp. 49, 56 n.27 (D. Mass. 1997).

241. See KeETON ET AL., supra note $234, \S 71$, at 509-10.

242. See, e.g., Hale v. Sheikholeslam, 724 F.2d 1205, 1207-08 (5th Cir. 1984) (holding that a plaintiff instituting a suit against an independent contractor physician who allegedly committed malpractice at a county hospital cannot hold the hospital liable for the physician's actions); Lee v. Regal Cruises, Ltd., 916 F. Supp. 300, 303 (S.D.N.Y. 1996) (discussing that because a ship's doctor was considered an independent contractor the shipowner was not liable for the purported malpractice of the doctor); Johnson v. Commodore Cruise Lines, Ltd., 897 F. Supp. 740, 745 (S.D.N.Y. 1995) (finding a shipowner not liable for the malpractice of a physician except when directly due to negligence in the selection of the physician); Jones v. Philpott, 702 F. Supp. 1210 (W.D. Pa. 1988) (holding that a physician is not an actual or ostensible agent of a hospital for purposes of malpractice claims); Freedman v. Kaiser Found. Health Plan, 849 P.2d 811, 816 (Colo. Ct. App. 1992) (stating that patients cannot hold an HMO responsible for the malpractice of its independent contractor physicians due to the statutory prohibition on HMOs practicing medicine); Raglin v. HMO Illinois, 595 N.E.2d 153, 156-58 (Ill. App. Ct. 1992) (finding that a health insurer and its HMO are not liable vicariously for negligence of physicians under contract with them to provide medical services to members of a health plan); Chase v. Indep. Practice Ass'n, 583 N.E.2d 251 (Mass. App. Ct. 1991) (finding an independent practice association that arranged with an HMO to provide services to HMO members is not vicariously liable for actions of the physicians in treating those members); Williams v. Good Health Plus, 743 S.W.2d 373 (Tex. App. 1987) (stating that an HMO is not liable for alleged negligence of physicians because it was incapable by statute of practicing medicine and because physicians delivering services were independent contractors). Note, however, that the corporate practice of medicine defense has been eliminated in Texas. See infra note 299 and accompanying text.

243. 595 N.E.2d 153 (Ill. App. Ct. 1992). 
through her employer, which had contracted with HMO Illinois. ${ }^{244}$ In turn, she obtained her physician services through a physician group that had contracted with HMO Illinois. On her initial visit, she reported a family history of diabetes. She subsequently became pregnant; however, even though her family history placed her at high risk for gestational diabetes, her physicians did not monitor her blood sugar levels during her pregnancy. ${ }^{245}$ During labor, the child's delivery was complicated by shoulder dystocia; in response to this complication, Raglin's physician attempted to deliver the child using forceps. In doing so, the child suffered brachial plexus injury and paralysis. Raglin then brought a medical malpractice suit directly against the physician and vicariously against HMO Illinois. ${ }^{246}$

The trial court granted summary judgment to HMO Illinois and Raglin appealed. ${ }^{247}$ The appellate court noted that the only way HMO Illinois could be held liable was through a vicarious-liability or ostensibleagency theory. ${ }^{248}$ The HMO did not directly employ its physicians but contracted with them to provide services, making them independent contractors. Consequently, the HMO could not be held indirectly liable unless Raglin proved an agency relationship based on either implied or apparent authority. ${ }^{249}$ The court found that, as a matter of law, even in circumstances where the HMO set up utilization review and quality assurance limitations and procedures to which its contractor physicians were required to adhere, the HMO's level of control was not sufficient to impute an agency relationship via implied authority and thereby bring the HMO within the liability circle of the contracting physicians. ${ }^{250}$ Furthermore, although the court noted that detrimental reliance by Raglin on an assurance from the HMO regarding the quality of care might establish apparent agency and defeat the independent contractor status, it held that requiring Raglin to select a physician from an approved list did not constitute a reasonable basis for her to assume that the HMO employed the physician and thus ensured quality care. ${ }^{251}$ The use of such lists, the court maintained, "is the manner in which all HMOs operate."252

244. See id. at 154.

245. See id. at 154-55.

246. See id. at 155.

247. See id.

248. See id. at 156.

249. See id.

250. See id. at 158 .

251. See id.

252. Id. 
The state court in Chase v. Independent Practice Association ${ }^{253}$ also considered the question of when an HMO or MCO would be considered liable under a vicarious-liability or ostensible-agency theory. The court first noted the standard consideration for determining whether vicarious liability applied: "The right to control an agent's activities has been the guiding principle in deciding cases involving an assertion of vicarious liability against the agent's principal." 254 The court then addressed a specific presumption regarding physicians:

Because of the high level of skill involved in the practice of medicine, physicians have traditionally been viewed as independent contractors, allowing hospitals and other medical centers to remain exempt from liability for negligent acts of a physician. - .

Surprisingly little case law exists on the liability of HMOs for the negligence of their participating physicians. That which does exist tends to suggest that the same principles of liability that have been applied to hospitals will apply to HMOs.

While the court observed that vicarious liability "will be applicable most often in a so-called staff-model HMO, where the HMO directly employs the physicians and pays them on a salaried, rather than fee-forservice basis,"256 it is important to note that the staff model is the leastfrequently used $\mathrm{MCO}$ structural model. ${ }^{257}$ The case centered on a member of an HMO alleging that the prenatal and obstetrical care provided was negligent and resulted in her child being born with cerebral palsy and retardation. She then brought a malpractice suit against the physicians directly, the independent practice association (IPA) that contracted with the physicians, and the HMO that contracted with the IPA for physician services. The plaintiff claimed that she did not select any of these physi-

253. 583 N.E.2d 251 (Mass. App. Ct. 1991).

254. Id. at 253 (quoting Kelley v. Rossi, 481 N.E.2d 1340, 1340 (Mass. 1985)).

255. Id. at 254 (citations omitted); see also William A. Chittenden III, Malpractice Liability and Managed Health Care: History and Prognosis, 26 TORT \& INS. L.J. 451, 454 (1991).

256. See Chase, 583 N.E.2d at 254; see also Diane J. Bearden \& Bryan J. Maedgen, Emerging Theories of Liability in the Managed Care Industry, 47 BAYLOR L. REv. 285, 299-301 (1995) (discussing the theory of vicarious liability in the context of managed care and analyzing cases applying the theory).

257. Only approximately $6 \%$ of enrollees are in staff-model HMOs; most are enrolled in IPA-model HMOs (51.5\%), while group-model plans cover approximately $25 \%$. See Scott Falk, POS, Medicare Products Boost Total HMO Membership to 66 Million, 3 Managed Care Rep. (BNA) 1110, 1112 (Dec. 3, 1997). Of course, this does not take into account the more than 55 million U.S. citizens enrolled in other forms of managed care such as PPOs, which are typically networks of providers who contract directly with employers on a discounted fee-for-service basis. See Paul J. Kenkel, PPOs Pursue New Links with Providers, MOD. HEALTHCARE, March 14, 1994, at 42; see also supra note 7 (discussing managed care forms and payment structures). 
cians and that she was unaware that these physicians were not employees of the HMO. The HMO imposed utilization review and preauthorization requirements upon the IPA by contract. Similar utilization review and preauthorization requirements were placed as an obligation by IPA onto the obstetrical group, which provided all obstetrical services to HMO members. The court held that there was no control on the part of the IPA over the actions of the physicians as a matter of law:

In the present case, the affidavits and contract documents submitted by the parties demonstrate, as a matter of law, that IPA did not control, or retain the right to control, the professional activities of [plaintiff's physician and her group practice].... [T] he plaintiff would be unable to prove at trial that any negligence on the part of [her physician] was attributable to IPA by virtue of its contractual arrangements with [the HMO] or [the group practice].

... Although the agreement between IPA and [the group practice] does provide for certain cost-containment and utilization review measures, it also makes clear that responsibility for the actual provision of medical treatment rests with [the group practice] and its employee-physicians. ${ }^{258}$

In addition to holding that the plaintiff's vicarious-liability claims were not tenable, the court rejected the plaintiff's ostensible-agency claims against the IPA:

IPA is also not liable under a theory of "ostensible" or "apparent" agency. Other courts ... have found that an HMO may be liable if the HMO creates an appearance that the physician is its employee, regardless of a physician's actual status.

...

... [But s]tanding alone, [plaintiff's] statement... that she was not "made aware that the doctors that were providing her prenatal care were not employees of [the HMO]" is insufficient to raise a claim of ostensible agency.... In order to hold IPA liable under an ostensible agency theory, there would have to be a showing of reliance on representations made by IPA, that [the physician and the group practice] were its agents or employees. $^{259}$

Thus, the court broadly rejected plaintiff's vicarious-liability and ostensible-agency claims in this prototypic managed care context. ${ }^{200}$

258. Chase, 583 N.E.2d at 253-54 (footnotes omitted).

259. Id. at 255 (citations omitted).

260. Because the IPA itself was held as a matter of law to be not liable, it seems unlikely that liability would have been extended to the HMO in the case, as it was a step further removed from the physicians. 
In Boyd v. Albert Einstein Medical Center, ${ }^{261}$ a case in which vicarious liability based on agency was not summarily rejected, the appellate court reversed a summary judgment for the defendant HMO and remanded the case for trial of the patient's vicarious-liability claim. Boyd received her health benefits through her spouse's employer, which contracted with HMO Pennsylvania for care. Boyd chose two physicians from the HMO's participating provider book as her primary care physicians; the physicians were independent contractors. When Boyd felt a lump in her breast, she contacted one of her primary care physicians, who ordered a mammogram and then referred her to a participating HMO surgeon for a biopsy. During the procedure, the surgeon perforated Boyd's chest wall, causing a pneumothorax. She was hospitalized, treated for this complication, and discharged. However, several weeks later, Boyd experienced chest pain and fatigue. Her spouse reported these symptoms to her primary care physicians. The physicians advised her to go to the hospital, where one of them examined her and arranged for a battery of tests at the physician's office. After returning home, she continued to experience symptoms and called her primary care physicians again. They prescribed a pain medication for her without further examination. At 5:30 p.m. that day, she was found dead by her spouse, having suffered a fatal heart attack. ${ }^{262}$

Boyd's spouse sued the physicians and the HMO for malpractice, basing the claim against the HMO on an ostensible-agency theory. The trial court granted summary judgment for the HMO and Boyd appealed. The appellate court reversed the judgment for the HMO. It believed that summary judgment was inappropriate because a question of material fact existed as to whether the HMO's participating physicians were ostensible agents of the HMO. The court noted that this case could be an exception to the general rule that an employer is not liable for the actions of independent contractors. Critically, the advertisements and brochures of the HMO stated that the HMO itself " "provides medical care, guarantees the quality of the care"" and "[a]ssumes the responsibility for quality and accessibility." ${ }^{263}$ The court indicated that Boyd could have reasonably relied on these statements, looked to the HMO for her care, and reasonably believed that the HMO held out the physicians as its employees. ${ }^{264}$

If not for the legally naive wording of the HMO advertisement and brochure, the MCO apparently would have been successful in having the trial court's summary judgment affirmed. Few if any MCO advertisements or brochures today would be so brazen in their claims and representations; most expressly note that all providers are independent con-

261. 547 A.2d 1229 (Pa. Super. Ct. 1988).

262. See id. at 1229-30.

263. Id. at $1232 \mathrm{n} .6$ (alteration in the original).

264. See id. at 1234. 
tractors with independent duties to the patient. ${ }^{265}$ Further, the court did not reject traditional principles of independent contractor law but simply remanded the case for trial. The court did not find the HMO liable. Consequently, protection through independent contractor status remains intact for MCOs. ${ }^{266}$

Thus, this common law protection, in combination with the statutory ERISA shield, provides MCOs with great latitude in deciding how much (or how little) care they will authorize contracting physicians to provide. The insulation that the MCOs enjoy from the costs associated with patient injury provides the distinct incentive to err on the side of authorizing less care rather than more.

\section{B. Physician Selection and Deselection: Adding Insult to Injury}

The introduction to this Part identified two legal implications of physicians' independent contractor status: the absence of vicarious liability for MCOs and the lack of good faith and public policy protections in physician terminations. These factors are essential to understanding the dynamics of the current healthcare marketplace and the relationships between key contracting parties. At the outset, it should be noted that physician access to patients is primarily, if not solely, obtained through managed care. ${ }^{267}$ Thus, for a physician to practice, he or she must be

265. See, e.g., PRUCARE HMO of California MEMber HandbooK 5 ("The relationship between PruCare and any participating hospital, physician or other healthcare provider is that of an independent contractor. Each participating provider has an independent professional responsibility to provide services to its patients. No participating hospital, physician or other healthcare provider is an employee or agent of PruCare.")

266. In an unusual and somewhat anomalous case, Schleier v. Kaiser Foundation Health Plan, 876 F.2d 174 (D.C. Cir. 1988), Kaiser Health Plan was found to be liable for the actions of an independent contractor physician who was a mere consultant to regular Kaiser physicians. The court, using the District of Columbia standard regarding when a "master-servant" relationship exists between an employer and independent contractor, found that one of Kaiser's physicians brought in the consultant physician, the Kaiser physician could "discharge" the consultant physician, and the consultant physician's actions "fell within the ambit of Kaiser's regular business," id. at 178, and that, as a result, the consultant's actions were attributable to Kaiser. Under the court's conception, there would be only narrow circumstances in which a physician acts independently and only a loose degree of "control" over the physician necessary to invoke vicarious liability. In fact, any independent contractor's actions would be imputed to the organization, because any independent contractor could be seen to be brought in and dischargeable by the organization, and the actions of the physician would be always considered as in the healthcare organization's regular business. Further, the court relied on an emergency room physician case to bolster its argument regarding the liability of the organization. See id. at 178. However, these emergency room physician cases are well circumscribed exceptions to the independent contractor rule. See BARRY FuRRow ET AL., 1 HEALTH LAw 456, 456 n.27 (1995).

267. See Marc A. Rodwin, Strains in the Fiduciary Metaphor: Divided Physician Loyalties and Obligations in a Changing Health Care System, 21 AM. J.L. \& MED. 241, 253 (1995). Rodwin notes:

Groups other than patients now have growing influence over physicians. Integrated 
"selected," i.e., chosen to be a provider for the MCO. Once selected, the physician subjects himself or herself by contract to practice and other MCO requirements, including the use of specific clinical practice guidelines, limitations on care decisions by management, standards of utilization review, varying methods of payment, and the all-important contractual control mechanism in the healthcare business-the terminationwithout-cause clause. These terms, proffered by a party with significant market power, are generally non-negotiable. The practice requirements, conditions, and limitations reflect an attempt by the MCO to address the significant financial pressures inherent in managing the costs associated with medical treatment and to provide the physician with incentives to minimize costs in the delivery context. In addition to the actual delivery of care, the physician must minimize costs in non-delivery areas of the MCO-provider relationship. If the physician wishes to remain with the $\mathrm{MCO}$, he or she cannot continually appeal care denials, request experimental treatments, inform patients of treatments not covered by the plan, or object vociferously to $\mathrm{MCO}$ policies and procedures that may compromise patient care. ${ }^{268}$ Hence, the physician selected by the MCO agrees to a very detailed behavioral structure.

If the physician exceeds pecuniary and non-pecuniary cost levels of the MCO, he or she risks the fate of "deselection:" The MCO will exercise its rights under the termination-without-cause clause. Again, there is generally no limit of good faith or public policy when terminating independent contractors. Because MCOs represent the primary player in U.S. healthcare finance, deselection by an MCO leads directly to cessation of income from the $\mathrm{MCO}$ and possible financial disaster for the physician. ${ }^{269}$

healthcare systems and managed care organizations often control the flow of patients to doctors. Third-party payers and managed care organizations control the flow of payments to physicians and set policies on what services are covered, rates for reimbursement, and the standard of care.

$I d$. Indeed, "[m]ost physicians must participate in some form of MCO because it is estimated that less than $5 \%$ of individuals not under a government program have a traditional indemnification insurance plan." Edward P. Richards \& Thomas R. McLean, Physicians in Managed Care: A Multidimensional Analysis of New Trends in Liability and Business Risk, $18 \mathrm{~J}$. LEGAL MED. 443, 447 (1997) (citing Christine C. Dodd, Comment, The Exclusion of Non-Physician Health-Care Providers from Integrated Delivery Systems: Group Boycott or Legitimate Business Practice?, 64 U. CIN. L. REV. 983 (1996)); see also Christine Wiebe, Utah Physicians Capitulate to Giant Network, AM. MED. NEwS, Feb. 3, 1998, at 3 (describing the failed effort by a group of physicians to establish practices independent of a regionally dominant $\mathrm{MCO}$ and quoting one of many doctors who returned to the HMO as explaining that "I have to feed my family" and that "[w]e were naïve" about the full impact of leaving the $\mathrm{MCO}$ ).

268. See Bryan A. Liang, The Practical Utility of Gag Clause Legislation, 13 J. GEN. INTERNAL MED. 419 (1998) [hereinafter Liang, Gag Clause Legislation].

269. See Liang, Deselection, supra note 46, at 854; see also Bryan A. Liang, Expensive Course of Treatment: Managed Care Organizations Should Bear a Burden for Malpractice, L.A. DAILY J., Apr. 15, 1996, at 6 [hereinafter Liang, Malpractice Burden]. 
Furthermore, other MCOs may perceive the deselected physician to be high-cost. Hence, deselection by one MCO may lead to difficulty in obtaining contracts with others. ${ }^{270}$ Because deselection has very significant consequences for a physician, he or she will attempt to avoid it in any way possible; indeed, his or her financial life may depend on it. This circumstance, in combination with MCO limited liability for driving down care levels through financial and other incentives, exacerbates the conflict between care and costs. The physician's incentives, in contrast to the MCO's, create mixed allegiances ${ }^{271}$ that compromise patient care. ${ }^{272}$

\section{Physician Liability}

It is important to note that, even in the significantly changed world of managed care, physicians retain the common law tort liability for patient injury they had under the fee-for-service system, regardless of the various legal maneuverings of managed care plans and plaintiffs. Although other areas of ERISA jurisprudence may be obscure, what is clear is that ERISA does not shield physicians from direct-liability malpractice actions:

Indeed, it is now well-accepted that the federal defense of ERISA preemption does not preempt professional malpractice actions [against physicians]... Common law medical malpractice is quintessentially the province of state authority. There is simply no reason to believe that Congress-by enacting a statute designed to protect the interests of workers in their benefit plans-intended to remove the long-standing protection against medical negligence afforded by state malpractice law.

Other courts are in accord: "ERISA does not generally preempt state professional malpractice actions." province of state malpractice law." ${ }^{275}$

270. See Richards \& McLean, supra note 267 , at 468 . The authors also note that beyond the loss of present and future income, physicians may be subject to non-compete clauses that require them to leave the community in order to find employment. See id.

271. See infra Part III (discussing the healthcare incentive structure created by law).

272. This concept is an ancient one. "No one can serve two masters; for either he will hate the one and love the other, or he will be devoted to the one and despise the other. You cannot serve God and mammon." Matthew 6:24 (King James).

273. Lancaster v. Kaiser Found. Health Plan, 958 F. Supp. 1137, 1149 (E.D. Va. 1997) (footnotes omitted).

274. Painters of Philadelphia Dist. Council No. 21 Welfare Fund v. Price Waterhouse, 879 F.2d 1146, 1153 n.7 (3d Cir. 1989); see also Edelen v. Osterman, 943 F. Supp. 75 (D.D.C. 1996) (holding that a medical malpractice claim against a podiatrist was not preempted by ERISA). But see Ouellette v. Christ Hosp., 942 F. Supp. 1160 (S.D. Ohio 1996) (holding that ERISA's civil enforcement provision does not completely preempt a malpractice action against an HMO).

275. Vickers v. Nash Gen. Hosp., 78 F.3d 139, 145 (4th Cir. 1996). 
Importantly, in modern healthcare law, state-law claims against MCOs based upon the use of financial incentive structures to direct physician behavior are held to be preempted by ERISA, while common law patient injury claims against the providers in these cases are not. ${ }^{276}$ And, of course, even in non-ERISA cases, these financial and other incentive structures have not brought MCOs into the liability circle. ${ }^{27}$ Thus, regardless of ERISA, the niceties of complete versus conflict preemption, common law pronouncements, and managed care financial structures, the physician still retains most if not all liability for any patient injury.

276. See Lancaster, 958 F. Supp. at 1149 (holding that ERISA does not preempt plaintiff's state-law medical malpractice claims); Pell v. Shmokler, No. CIV. A. 96-6002, 1997 WL 83743, at *5 (E.D. Pa. Feb. 20, 1997) ("[T]o the extent that plaintiff has premised her tort claim on defendant's alleged practice of wrongfully discouraging referrals and limiting care, it is completely preempted by ERISA."); Kearney v. U.S. Healthcare, 859 F. Supp. 182, 187 (E.D. Pa. 1994) ("A claim that participating primary care physicians were restricted or discouraged for economic reasons from referring beneficiaries to specialists or hospitals or from using the most state of the art diagnostic tests merely ascribes to a defendant a motive for failing to provide certain benefits and is preempted [by ERISA]."); Kohn v. Delaware Valley HMO, No. 91-2745, 1991 WL 275609 (E.D. Pa. Dec. 20, 1991) (holding that claims against an HMO plan for failure to provide promised benefits and for discouraging referrals to specialists were preempted).

Challenges based on utilization review systems have also been held to be preempted. See Lancaster, 958 F. Supp. at 1147 ("Courts that have examined this policy have uniformly found that challenges to such pre-certification decisions are either completely preempted under $\$ 502(\mathrm{a})(1)$ (B) or subject to an ERISA preemption defense under \$ 514(a)."); see also Kuhl v. Lincoln Nat'l Health Plan, 999 F.2d 298, 302 (8th Cir. 1993); Corcoran v. United Healthcare, 965 F.2d 1321, 1332 (5th Cir. 1992). Note, however, Shea v. Esensten, 107 F.3d 625 (8th Cir. 1997), cert. denied, 118 S. Ct. 297 (1997), in which the court considered whether ERISA preempted a wrongful death claim against an HMO based on a physician incentive program. In the case, the plaintiff's husband visited his primary care physician several times complaining of severe chest pains, shortness of breath, dizziness, and muscle tingling. Despite these cardiac warning signs and the husband's family history of heart disease, the primary care physician indicated to the husband that his symptoms did not warrant a cardiac referral. Tragically, several months after his visits to the primary care physician, the husband died of heart failure. His HMO, Medica, had instituted a financial incentive policy that rewarded its primary care doctors for not referring patients to specialists. Thus, his spouse sued the HMO for fraudulent nondisclosure and misrepresentation in state court. The HMO removed the case to federal court. The spouse then amended her complaint to bring a claim that the HMO's administrative policy of reducing referrals violated its fiduciary duties under sections 3 and 404 of ERISA, 29 U.S.C. $\S \S$ 1002(21), 1104(a) (West 1985 \& Supp. 1998). The district court dismissed the case but the court of appeals reversed, holding that there may have been a duty on the part of the HMO to disclose the financial incentive structure under an ERISA fiduciary theory. The court of appeals did affirm the holding below that ERISA's preemption provision superseded plaintiff's statelaw claims for misrepresentation and fraudulent nondisclosure.

277. See supra notes $243-260$ and accompanying text (discussing physician independent contractor cases in which there was no recourse against MCOs even though incentive and care structures were set up by MCOs). 


\section{TORN ASUNDER: MODERN HEALTH CARE INCENTIVES AND PATIENT INJURY}

The incentives created by the legal system have placed the major parties in the healthcare delivery system at odds with each other. The system no longer focuses on providing care to the patient. This result has not only created difficulties in the general healthcare environment but also created a system where efforts to reduce patient injury will have little chance for implementation. Thus, the legal system has created a healthcare delivery structure wherein the focus has shifted from care to costs and provides significant barriers to changing that pecuniary perspective.

\section{A. Bottom Line Party Incentives}

From the description of the legal framework indicated in this Article, today's healthcare system, as compared with the traditional fee-forservice system, has a fundamentally different set of incentive structures that are no longer aligned toward providing appropriate levels of patient care. Although the once-broad interpretation of ERISA preemption has been limited in recent cases, ${ }^{278}$ an MCO, even under modern ERISA ju-

278. Earlier cases described ERISA preemption of state-law claims in extremely broad, allencompassing terms. See FMC Corp. v. Holliday, 498 U.S. 52, 58 (1990) (describing ERISA preemption as "conspicuous for its breadth"); Pilot Life Ins. Co. v. Dedeaux, 481 U.S. 41 (1987) (noting preemption in ERISA is "deliberately expansive, and designed to establish pension plan regulation as exclusively a federal concern"); Metropolitan Life Ins. Co. v. Massachusetts, 471 U.S. 724, 739 (1985) (holding that ERISA preemption should be "given its broad, commonsense meaning"). More recent cases have seen what one court characterized as an "abrupt] abandon[ment] of this strict textualist interpretation," Andrews-Clarke v. Travelers Ins. Co., 984 F. Supp. 49, 57 (D. Mass. 1997), and the emergence of an interpretation that holds that "a law operating as an indirect source of merely economic influence on administrative decisions ... should not suffice to trigger preemption," New York Conference of Blue Cross \& Blue Shield Plans v. Travelers Ins. Co., 514 U.S. 645, 662 (1995). Note, however, that although Travelers and its progeny are heralded as the liberalization of ERISA suits, see id. at 660-62; California Div. of Labor Standards Enforcement v. Dillingham Constr., N.A., 117 S. Ct. 832 (1997); De Buono v. NYSA-ILA Med. \& Clinical Serv. Fund, 117 S. Ct 1671 (1995), the Supreme Court had indicated previously that preemption was not without limit, see, e.g., Mackey v. Lanier Collection Agency \& Serv., 486 U.S. 825, 841 (1988) (indicating that the burden of collecting judgments against an ERISA plan through a state garnishment statute was not dispositive in deciding whether the state law "relates to" the EBP); Shaw v. Delta Air Lines, 463 U.S. 85, 100 n.21 (1983) ("Some state actions may affect employee benefit plans in too tenuous, remote, or peripheral a manner to warrant a finding that the law 'relates to' the plan."). Indeed, Travelers itself stressed that Pilot Life is still good law. See Travelers Ins. Co., 514 U.S. at 668; see also Margaret G. Farrell, ERISA Preemption and Regulation of Managed Health Care: The Case for Managed Federalism, 23 AM. J.L. \& MED. 251 (1997) (arguing that the Supreme Court's ERISA jurisprudence is too literal and that preemption should be assessed on the basis of shared federal and state legislative authority); Larry J. Pittman, ERISA's Preemption Clause and the Health Care Industry: An Abdication of Judicial Law-Creating Authority, 46 FLA. L. REV. 355 (1994) (arguing that ERISA preemption should not apply to direct- and vicariousliability suits against healthcare organizations and providers); L. Frank Coan, Jr., Note, You 
risprudence, has a strong incentive to deny patient care so as to fit within the statute's civil enforcement provision ${ }^{279}$ and thus have plaintiffs' statelaw claims completely preempted. The MCO can, because of its control over access to patients and the physician independent contractor status, bring to bear on the physician significant pressures to minimize patient care and delivery costs through a broad array of incentive structures, requirements, and limitations. Because it often faces no liability due to the shields of ERISA and independent contractor law, the MCO will want to push care levels down as low as possible.

Patients, on the other hand, have the opposite incentive; they wish to have more care ${ }^{2 s 0}$ authorized by their MCOs because of their increased need for it as they age. This need for more care is particularly important in the context of multisystem disease, which requires attention to complex physiological and treatment interactions, and longer life, which heightens the desire for effective medical interventions that will maintain and improve its quality. Also, although patients may have no recourse against the $\mathrm{MCO}$, they always have recourse against the provider. ${ }^{281}$ Thus, patients can demand more care from their physicians with the legitimate threat of suit if care is not provided and injury occurs.

Physicians, lodged in the middle between MCOs and patients, have severely conflicting incentives. On the one hand, they have a professional and ethical responsibility to provide the appropriate amount of care consonant with patient needs; further, they have a legal imperative to do so since they shoulder virtually all potential liability for patient injury. ${ }^{282} \mathrm{On}$ the other hand, financial pressures and the threat of deselection directly

Can't Get There from Here-Questioning the Erosion of ERISA Preemption in Medical Malpractice Actions Against HMOs, 30 GA. L. REV. 1023, 1056-60 (1996) (advocating consistent jurisprudential analysis to find vicarious-liability claims not preempted by ERISA); Rebecca S. Fellman-Caldwell, Note, New York State Conference of Blue Cross \& Blue Shield Plans v. Travelers Insurance Co.: The Supreme Court Clarifies ERISA Preemption, 45 CATH. U. L. REV. 1309 (1996) (reviewing the scope of preemption pre-Travelers and the impact of Travelers on state healthcare reform); David T. Shapiro, Note, The Remission of ERISA Preemption: An Examination of Blue Cross/Blue Shield v. Travelers Insurance Co., 28 CONN. L. REv. 917 (1996) (reviewing Travelers and indicating that a new standard for ERISA $\$ 514$ will allow additional efforts on the state level for healthcare teform); F. Christopher Wethy, Note, New York Conference of Blue Cross \& Blue Shield Plans v. Travelers Insurance Co.: Vicarious Liability Malpractice Claims Against Managed Care Organizations, 37 B.C. L. REv. 813 (1996) (opposing preemption of vicarious-liability suits against ERISA MCOs).

279. Indeed, the crack in this shield, Dukes v. U.S. Healthcare, 57 F.3d 350, further solidifies this incentive. See supra Sections I.D-F.

280. Note that although enrollees as patients desire more care because of their need for it, as employees, they wish to minimize the costs of this care.

281. See supra Section II.C (discussing physician liability).

282. See Barry R. Furrow, Litigation over QualtTy in Managed Care: INdividual Malpractice/NEGligence Claims in ARBITRation and LITIGation 1, 13 (1995). 
contravene their ability to provide or even suggest the level of care they deem appropriate Referrals, experimental treatments, and treatments not covered by the MCO may be extremely difficult to procure under these circumstances. ${ }^{283}$ Simply put, being an advocate for and attempting to fulfill ethical obligations to patients can get a physician fired. ${ }^{2 s 4}$

No easy highbrow ethical answers to this dilemma present themselves. Certainly, it is no answer that physicians should simply refuse to enter into such agreements or should simply "find a way" to obtain the best care for their patients within the constraints of an MCO agreement. First, with the extensive penetration of managed care, physicians cannot ignore the managed care market or demand changes in the standard contractual arrangements if they wish to practice. Second, although some physicians can afford to give up practice because they object to the financial and other constraints that, they believe, interfere substantively and ethically with providing appropriate treatment to their patients, most physicians, with families to feed, bills to pay, and other creditors to oblige, do not have the luxury of such a choice. They must simultaneously fulfill ethical obligations both to their patients and to their families and creditors and thus cannot simply ignore the dictates of their financial lifeline. ${ }^{235}$ Hence, the incentives of the payer, provider, and patient are very much askew in the healthcare system of the United States today, leaving physicians "quite literally, caught in the middle in the battle over treatment between patients and the HMOs." ${ }^{\text {286 }}$ One of the implications of this misalignment, this Article has argued, is that the liability structure developed under the fee-for-service healthcare system may not be appropriate for the managed care system that dominates healthcare delivery in the United States today. ${ }^{287}$

283. See Liang, Gag Clause Legislation, supra note 268.

284. This conflict for medical providers has been recognized:

It is unacceptable to place a physician in a position, implied or explicit, that involves choosing between the pull of the group's need to divide shared resources and the need of his or her individual patient.

... The conflict created by placing a physician in a position of deciding whether to provide or offer a service to a patient that will affect the amount of income the physician receives is not acceptable.

F. Ronald Feinstein, Plastic Surgery and the Challenges of the Managed Care Marketplace: Where Did the Money Go?, 98 PLASTIC \& RECONSTRUCTIVE SURGERY 1068, 1070 (1996).

285. See Liang, Gag Clause Legislation, supra note 268, at 420.

286. Richard C. Reuben, In Pursuit of Health: With More Patients Suing HMOs for Denial of Treatment Lawyers Are Exploring New Ground in Going up Against the Managed Care Giant, A.B.A. J., Oct. 1996, at 55, 58.

287. The political nature of resource allocation in healthcare today requires that the polity make a commitment to a specific approach; indeed, "decisions for the prioritizing of spending for healthcare are political to the extreme and physicians should not be forced into making choices alone that society as a whole does not appear ready to make." Feinstein, supra note 284, 


\section{B. Adverse Effects on Patient Injury Research and Implementation}

The legally created incentive structures of the parties within the healthcare delivery system also impede progress in efforts to reduce patient injury. ${ }^{288}$ Because of ERISA and the law of independent contractors, MCOs are shielded from tort liability. Thus, the responsibility of malpractice liability and other tort causes of action falls upon physicians when patient injury occurs. However, the tort system does not appear to alter physician behavior so as to reduce patient injury, ${ }^{259}$ indeed, because of physicians' misperceptions of the system and disagreements with juries regarding medically appropriate care, the tort system as currently structured gives physicians incentives to practice both positive and negative defensive medicine, paradoxically increasing the risk of patient injury. ${ }^{200}$ Organizationally, if MCOs were responsible for costs associated with patient injury, they would have an incentive to use their large patient and physician base to investigate what causes error in medicine and what structural and systematic changes could reduce the risk of error, as other complex industries have done. ${ }^{291}$ This effort would be advantageous for the MCO because it is an investment that not only reduces operational $\operatorname{costs}^{222}$ but also increases marketability of the plan by demonstrating participation in this important research and providing a benchmark of patient injury levels for comparison with competitors' levels. At present,

at 1070 .

288. See Bryan A. Liang, Error in Medicine: Legal Impediments to U.S. Reform, J. HEALTH POLITICS, POL'Y \& L. (forthcoming 1999) (manuscript on file with the Yale Law \& Policy Review) [hereinafter Liang, Legal Impediments].

289. Physicians, it has been shown, poorly understand the tort system, which is thus an apparently ineffective incentive structure for optimizing physician behavior and compensating patients. See id; see also PaUl C. WeILER ET AL., A MEASURE of MaLPRACTrCE: Medical INJURY, MALPRACTICE LITIGATION, AND PATIENT COMPENSATION 74-75 (1993) (stating that only approximately one of 16 negligently injured patients is compensated through the tort system). See generally Liang, Jury Verdicts, supra note 138 (suggesting that physicians have poor knowledge of the negligence rule); Liang, Medical Malpractice, supra note 138 (same).

290. See Liang, Jury Verdicts, supra note 138; Liang, Legal Impediments, supra note 288 (manuscript at 9-10). Defensive medicine is the provision or avoidance of rendering healthcare on the basis of liability concerns rather than clinical indication. Positive defensive medicine is care provided due to liability concerns (e.g., additional tests or procedures); negative defensive medicine is care avoided due to liability concerns (e.g., obstetrician-gynecologists not providing obstetrical care). See id.

291. See, e.g., Daniel E. Maurino et al., Beyond Aviation Human Factors (1995) (discussing the aviation industry, which has made significant progress in reducing error and risk of injury in flight); JAMES REASON, HUMAN ERROR (1990) (discussing aviation and other industries that have made systematic changes and reduced error and injury).

292. Reduced operational costs would include a reduction in litigation costs associated with patient injury suits due to improved patient safety. Here I assume that MCO litigation costs associated with answer, removal, and summary judgment litigation in federal court would be less than full adjudication and possible damage awards in state court. 
MCOs generally have an incentive to compete only on cost rather than quality of care.

Further, the MCO's lack of interest in quality improvement will make individual providers reluctant to participate independently in innovative efforts to minimize patient injury. Without some form of immunity or indemnity for patient injuries that arise from process changes inevitably required by such efforts, physicians simply will not wish to take the risk of implementing new systems. ${ }^{29}$

The threat of deselection under termination-without-cause clauses makes participation in patient injury research and implementation appear even more undesirable to physicians. Voluntary participation by providers would require significant time and effort that may reduce their productivity and, potentially, subject them to termination. Hence, physicians will refuse to participate in this research on the basis of legitimate concerns regarding employment. ${ }^{295}$ Indeed, the threat of deselection encourages providers with $\mathrm{MCO}$ contracts to avoid even the mere implementation of already researched patient-injury-reducing processes. Because of the significant learning curve that must be climbed when implementing any new process, diagnosing and treating patients may be more time-consuming and render some or all of a physician's knowledge in a particular medical area obsolete. Thus, there is little hope that there will be broad-based support for patient injury research from either physicians or the MCOs with whom they contract. ${ }^{296}$

293. MCO administrator and manager compensation schemes are generally tied to financial performance rather than to quality of care, patient satisfaction, or reductions in morbidity or mortality. See Kathryn Desmond, Compensation Gaps Widening Between MCOs, Hospitals, Mercer Study Says, 3 Managed Care Rep. (BNA) 672 (July 16, 1997); see also Dayna Bowen Matthew, Controlling the Reverse Agency Costs of Employment-Based Health Insurance: Of Markets, Costs and a Regulatory Quagmire, 31 WAKE FOREST L. REV. 1037, 1038 (1996) ("Assuming employers are also rational utility maximizers, their objective is to minimize the cost of obtaining the level and quality of health insurance that the labor market, relevant to the employer's enterprise, demands."). However, there has been a movement, at least among some large corporations, toward looking to quality indicators. See infra note 419.

294. See Liang, Legal Impediments, supra note 288, (manuscript at 21) (citing Leigh Page, Doctors Want Extra Pay for Managed Care Paperwork, AM. MED. NEws, July 14, 1997, at 6).

295. See Liang, Legal Impediments, supra note 288 (manuscript at 22-23). Challenges to termination under termination-without cause clauses are generally futile. See Liang, Deselection, supra note 46; Liang, Gag Clause Legislation, supra note 268; supra text accompanying notes 46 \& 268; see also Bryan A. Liang, An Overview and Analysis of Challenges to Medical Exclusive Contracts, 18 J. LEGAL MED. 1 (1997) (discussing termination-without-cause clauses in context of exclusive contracts).

296. See id. 


\section{Current Proposals: Missing the BoAT}

Although there has been some recognition of the difficulties in the managed care system and some efforts made to intervene, this Part will argue that current proposals are of limited use because they do not address the incentive structures created by the legal system. Leading state efforts allowing direct suit against MCOs and patient protection bills introduced in Congress miss the boat by not comprehensively addressing the incentives created by ERISA, independent contractor law, and deselection.

\section{A. State Proposals: Theme One-Suing MCOs}

The difficulties encountered by patients and physicians in the new healthcare environment are founded upon the creation of specific incentives under both statutory and common law. Courts have expressed significant frustration in assessing the relative rights and responsibilities of the patient, physician, and MCO under the current regime. ${ }^{297}$

Recognizing at least some of these difficulties, there have been some legislative activities on the state level that attempt to rectify the MCO liability loophole. The most prominent among these is a Texas statute that allows direct suit against an MCO for patient injury if it does not exercise "ordinary care" in patient care decisions. ${ }^{298}$ The Texas statute purport-

297. See, e.g., Turner v. Fallon Community Health Plan, 127 F.3d 196, 200-01 (1st Cir. 1997) (Hill, J., concurring) ("Appellant, recognizing that the statutory and case law compels the district court's grant of summary judgment to appellee, addresses entreaties to us which, if appropriate at all, are appropriate to the legislative branch. Periodic accusations to the contrary notwithstanding, the courts are not legislative bodies."); Corcoran v. United HealthCare, 965 F.2d 1321, 1338-39 (5th Cir. 1992) ("Fundamental changes such as the widespread institution of utilization review would seem to warrant a reevaluation of ERISA so that it can continue to service its noble purpose of safeguarding the interests of employees. Our system, of course, allocates this task to Congress, not the courts . ..."); Andrews-Clarke v. Travelers Ins. Co., 984 F. Supp. 49, 65 (D. Mass. 1997) ("Although the alleged conduct of [defendant MCO and utilization review companies] in this case is extraordinarily troubling, even more disturbing to this Court is the failure of Congress to amend a statute that, due to the changing realities of the modern healthcare system, has gone conspicuously awry from its original intent. Does anyone care? Do you?").

298. See 1998 TEX. CrV. PraC. \& REM. CODE ANN. $\$ \$ 88.001-.003$ (West 1998). The statute reads in part as follows:

$\S 88.002$. Application

(a) A health insurance carrier, health maintenance organization, or other managed care entity for a healthcare plan has the duty to exercise ordinary care when making healthcare treatment decisions and is liable for damages for harm to an insured or enrollee proximately caused by its failure to exercise such ordinary care.

(b) A health insurance carrier, health maintenance organization, or other managed care entity for a healthcare plan is also liable for damages for harm to an insured or enrollee proximately caused by the healthcare treatment decisions made by its:

(1) employees; 
(2) agents;

(3) ostensible agents; or

(4) representatives who are acting on its behalf and over whom it has the right to exercise influence or control or has actually exercised influence or control which results in the failure to exercise ordinary care.

(c) It shall be a defense to any action asserted against a health insurance carrier, health maintenance organization, or other managed care entity for a healthcare plan that:

(1) neither the health insurance carrier, health maintenance organization, or other managed care entity, nor any employee, agent, ostensible agent, or representative for whose conduct such health insurance carrier, health maintenance organization, or other managed care entity is liable under Subsection (b), controlled, influenced, or participated in the healthcare treatment decision; and

(2) the health insurance carrier, health maintenance organization, or other managed care entity did not deny or delay payment for any treatment prescribed or recommended by a provider to the insured or enrollee.

(d) The standards in Subsections (a) and (b) create no obligation on the part of the health insurance carrier, health maintenance organization, or other managed care entity to provide to an insured or enrollee treatment which is not covered by the healthcare plan of the entity.

(e) This chapter does not create any liability on the part of an employer, an employer group purchasing organization, or a pharmacy licensed by the State Board of Pharmacy that purchases coverage or assumes risk on behalf of its employees.

(f) A health insurance carrier, health maintenance organization, or managed care entity may not remove a physician or healthcare provider from its plan or refuse to renew the physician or healthcare provider with its plan for advocating on behalf of an enrollee for appropriate and medically necessary healthcare for the enrollee.

(g) A health insurance carrier, health maintenance organization, or other managed care entity may not enter into a contract with a physician, hospital, or other healthcare provider or pharmaceutical company which includes an indemnification or hold harmless clause for the acts or conduct of the health insurance carrier, health maintenance organization, or other managed care entity. Any such indemnification or hold harmless clause in an existing contract is hereby declared void.

(h) Nothing in any law of this state prohibiting a health insurance carrier, health maintenance organization, or other managed care entity from practicing medicine or being licensed to practice medicine may be asserted as a defense by such health insurance carrier, health maintenance organization, or other managed care entity in an action brought against it pursuant to this section or any other law.

(i) In an action against a health insurance carrier, health maintenance organization, or managed care entity, a finding that a physician or other healthcare provider is an employee, agent, ostensible agent, or representative of such health insurance carrier, health maintenance organization, or managed care entity shall not be based solely on proof that such person's name appears in a listing of approved physicians or healthcare providers made available to insureds or enrollees under a healthcare plan.

(j) This chapter does not apply to workers' compensation insurance coverage as defined in Section 401.011, Labor Code.

(k) An enrollee who files an action under this chapter shall comply with the requirements of Section 13.01, Medical Liability and Insurance Improvement Act of Texas (Article 4590i, Vernon's Texas Civil Statutes), as it relates to cost bonds, deposits, and expert reports.

Id. $\$ 88.002$ 


\section{Patient Injury Incentives}

edly allows recourse against MCOs in the courts for negligently injured patients, both by removing the corporate practice of medicine defense $\mathrm{e}^{299}$ recognized by some courts to protect MCÓs from suit ${ }^{300}$ and by expressly allowing direct suit against MCOs for any failure to exercise ordinary care. $^{301}$

There are, however, several problems with this statute as well as proposed state statutes similar to it. ${ }^{302}$ First, the Texas statute by its terms may not provide the relief for patients that its drafters desired. The statute expressly indicates that:

(a) A health insurance carrier, health maintenance organization, or other managed care entity for a healthcare plan has the duty to exercise ordinary care when making healthcare treatment decisions and is liable for damages for harm to an insured or enrollee proximately caused by its failure to exercise ordinary care. ${ }^{303}$

"Ordinary care" for healthcare organizations such as MCOs is defined as:

[T]hat degree of care that a health insurance carrier, health maintenance organization, or managed care entity of ordinary prudence would use under the same or similar circumstances. In the case of a person who is an employee, agent, ostensible agent, or representative of a health insurance carrier, health maintenance organization, or managed care entity, "ordinary care" means that degree of care that a person of ordinary prudence in the same profes-

299. See id. $\$ 88.002(\mathrm{~h})$. The corporate practice of medicine doctrine prohibits corporations and other business forms from practicing medicine. See FURROW, supra note 266, § 5-10, at 183 (1995). Thus, MCOs have avoided suit because they "cannot be sued for medical malpractice if they are prohibited from "practicing medicine." Patricia A. Butler, Managed Care Liability: An

Analysis of Texas and Missouri Legislation (visited Nov. 4, 1998) <http://www.kff.org/kff/library.html?document_key=2047\&data_type_key=268>; see also FURROW, supra note $266, \S 5-10$ (b) (reviewing cases). Like Texas, Missouri has expressly eliminated the corporate practice of medicine defense for health maintenance organizations (although not other MCOs). See MO. ANN. STAT. § 354.505 (West 1997) (amending statute to repeal the provision that "[a]ny health maintenance organization ... shall not be deemed to be practicing medicine").

300. See, e.g., McVay v. Rich, 859 P.2d 399 (Kan. Ct. App. 1993); Pickett v. CIGNA Fealth Plan, 1993 WL 209858 (Tex. App. 1993); Williams v. Good Health Plus, 743 S.W.2d 373 (Tex. App. 1987); Hunte v. Hinkley, 731 S.W.2d 570 (Tex. App. 1987).

301. See TeX. Civ. PraC. \& Rem. Code ANn. \$ 88.002(a), (b) (West 1998).

302. There have been several such proposals. See, e.g., C.A. A.C.A. 36, Reg. Sess. (Cal. 1997); H.B. 1205, 61st Gen. Assem., 2d Reg. Sess. (Colo. 1998); S.B. 490, Reg. Sess. (Fla. 1998); H.B. 3435, 19th Leg., Reg. Sess. (Haw. 1998); H.B. 1207, 110th Gen. Assem., 2d Reg. Sess. (Ind. 1998); S.B. 84, Reg. Sess. (Md. 1998); H.B. 1628, 155th Gen. Ct., Reg. Sess. (N.H. 1997); see also infra notes 328-330 (reviewing state legislative efforts); H.B. 677, 122d Gen. Assem., Reg. Sess. (Ohio 1997); H.B. 2800, 100th Gen. Assem., Reg. Sess. (Tenn. 1998).

303. TEX. Civ. PraC. \& REM. CODE ANN. $\$ 88.002(a)$. 
sion, specialty, or area of practice as such person would use in the same or similar circumstances. ${ }^{304}$

On its face, a difficulty with this language is that the relevant prescribed standard to assess the MCO's activities is what an ordinary $M C O$ would decide in similar circumstances. Thus, the inquiry focuses not necessarily upon the most appropriate medical treatment that a physician in good standing and in the relevant specialty would recommend in the best interest of the patient, but rather what standard of behavior a typical MCO would follow. There is a significant possibility that these standards may conflict.

But, some may say, there is the standard of protection within the statute of "ordinary care" as exercised by the MCO's employee, agent, ostensible agent, or representative (presumably the legislature had in mind a physician), who must conform to his or her profession (presumably medicine). However, the difficulty here lies in the use of the terms "employee, agent, ostensible agent, or representative." As indicated above, ${ }^{305}$ physicians generally contract with MCOs as independent contractors who, because of that status, are generally not considered employees, agents, ostensible agents, or representatives of the MCOs.

Beyond the standard-of-behavior issue, there is a deeper problem. The statute, in any attempted application against an ERISA EBP, may be preempted by ERISA's preemption provision; indeed, the statute is currently being challenged on this basis. ${ }^{306}$ Since it appears that the Texas statute must be considered "the regulation of insurance" in order to escape preemption, ${ }^{307}$ it must fall within the established saving clause jurisprudence. However, if this is so, its hope of survival may rest on very shaky ground. Beyond the traditional rejection of direct-liability suits in tort and contract against ERISA MCOs under ERISA's civil enforcement provision, ${ }^{308}$ the Supreme Court in Pilot Life Insurance Co. v.

304. Id. $\$ 88.001(10)$.

305. See supra notes 232-233 and accompanying text (discussing independent contractors); supra Section II.A.

306. See Corporate Health Ins. v. Texas Dep't. of Ins., 12 F. Supp. 2d 597 (S.D. Tex. 1998) (holding that the provisions of the Texas statute making managed care entities liable for substandard healthcare treatment decisions are not preempted by ERISA, but that those provisions that prohibit the plan from removing providers for patient advocacy efforts are preempted). Both sides have appealed the decision to the Fifth Circuit. See Aetna U.S. Healthcare Announces Intent to Appeal HMO Liability Ruling, 6 Health Care Pol'y Rep. (BNA) 1727 (Nov. 2, 1998).

307. See 29 U.S.C. $\$ 1144(b)(2)$ (a) (1994) ("[N]othing in this subchapter [of ERISA] shall be construed to exempt or relieve any person from any law of any State which regulates insurance, banking, or securities"). The Texas statute clearly does not fall within the last two exceptions and thus must be a law that regulates insurance in order to be within the saving clause exception.

308. See supra Section I.C (discussing direct-liability suits against ERISA MCOs and their 


\section{Patient Injury Incentives}

Dedeaux ${ }^{309}$ adopted a "common sense" initial assessment and the three McCarran-Ferguson Act ${ }^{310}$ criteria to assess whether a particular state law is within the business-of-insurance exception.

First, as the Court noted in Pilot Life, "[a] common-sense view of the word 'regulates' would lead to the conclusion that in order to regulate insurance, a law must not just have an impact on the insurance industry, but must be specifically directed toward that industry.",311 This would lead to the conclusion that the Texas statute does not fall within the saving clause with regard to insurance because it does not direct its effects specifically to the insurance industry but merely toward managed care plans. ${ }^{312}$

Second, the three McCarran-Ferguson criteria are "[f]irst, whether the practice has the effect of transferring or spreading a policyholder's risk; second, whether the practice is an integral part of the policy relationship between the insurer and the insured; and third, whether the practice is limited to entities within the insurance industry. ${ }^{313}$ In Metropolitan Life Insurance Co. v. Massachusetts ${ }^{314}$ the Supreme Court held that a statute mandating mental health benefits that applied to the insurance industry in the state fell within the saving clause for insurance. ${ }^{315}$ Using the three-part McCarran-Ferguson test, the Court concluded that the statute

obviously regulates the spreading of risk ... [by] effectuat[ing] the legislative judgment that the risk of mental-healthcare should be shared. It is also evident that the mandated-benefit laws directly regulate an integral part of the relationship between the insurer and the policyholder by limiting the type of insurance that an insurer may sell to the policyholder. Finally, the third criterion is present here, for mandated-benefit statutes impose requirements only on insurers, with the intent of affecting the relationship between the insurer and policyholder. [The state statute], then, is the very kind of regulation that this Court has identified as a law that relates to the regulation of the business of insurance....

lack of success).

309. 481 U.S. 41 (1987).

310. 15 U.S.C.A. $\$ \S 1011-1015$ (West 1997).

311. Pilot Life Ins. Co., 481 U.S. at 50 (emphasis added).

312. The Texas statute is applicable to "[a] health insurance carrier, health maintenance organization, or other managed care entity...." TEX. CTV. PRAC. \& REM. CODE ANN. $\S 88.002$ (a) (emphasis added).

313. Pilot Life Ins. Co. at $48-49$ (quoting Union Labor Life Ins. Co. v. Pireno, 458 U.S. 119, $129(1982))$.

314. 471 U.S. 724 (1985).

315. See id. at 727.

316. Id. at 743 (citation omitted). 
In contrast, the Texas statute does not meet the tests. It does not regulate the spreading of actuarial risk across the policyholders in the Texas insurance market; rather, it imposes potential liability upon certain portions of and entities in the insurance market. ${ }^{317}$ It does not represent an integral part of the policy relationships through, for example, the Metropolitan Life conception of the type of insurance that can be sold by the insurer to the policyholder, ${ }^{318}$ for again, it is simply a liability statute. Finally, it does not limit its scope to the entities of the insurance industry; all forms of managed care, including those that bear risk and those that do not, ${ }^{319}$ are encompassed by the statute. ${ }^{320}$ This is not, therefore, the "very kind of regulation ... that relates to the regulation of the business

317. See Tingle v. Pacific Mut. Ins. Co., 996 F.2d 105 (5th Cir. 1993) (holding that a Louisiana statute that preserved under state law certain claims against insurance policies-those presented by insureds who had made misrepresentations on the insurance contract but did so without actual intent to deceive-was not saved from preemption by the saving clause because it did not spread risk); see also Smith v. Jefferson Pilot Life Ins. Co., 14 F.3d 562 (11th Cir. 1994) (holding that a Georgia statute that mandated notice to an insured prior to termination of coverage was not saved because the statute did not have the effect of spreading risk).

318. See Metropolitan Life Ins. Co., 471 U.S. at 743.

319. For example, the PPO, a model of managed care, would be subject to the Texas statute even though it does not generally assume risk and operates instead on a discounted fee-forservice basis. See supra note 7 (discussing managed care forms).

320. In Stuart Circle Hospital Corp. v. Aetna Health Management, 995 F.2d 500, 505 (4th Cir. 1993), the Fourth Circuit Court of Appeals held that a Virginia statute that prohibited unreasonable discrimination by health insurers when forming PPOs was not preempted by ERISA; the court, although applying the common-sense and three-part McCarran-Ferguson tests, held that the statute was not preempted because it limited its effects to entities of the insurance industry-i.e., it did not reach employer-funded PPOs. Consistent with this analysis, other courts have held that statutes that require MCOs to use all providers that are willing to contract on its terms ("any-willing-provider laws") are preempted if they are not limited in scope. See Texas Pharmacy Ass'n v. Prudential Ins. Co., 105 F.3d 1035, 1038-39 (5th Cir. 1997) (holding that Texas's any-willing-pharmacy-provider statute is preempted by ERISA on the basis of the statute's application to HMOs, PPOs, and other MCOs rather than being limited to entities within the insurance industry); CIGNA Healthplan v. Louisiana, 82 F.3d 642, 650 (5th Cir. 1996) (holding that Louisiana's any-willing-provider law is preempted by ERISA because it attempted to include employer self-funded plans in its regulatory purview and is thus not limited to entities within the insurance industry); see also Prudential Ins. Co. v. National Park Med. Ctr., 964 F. Supp. 1285, 1299-1300 (E.D. Ark. 1997) (holding that Arkansas's Patient Protection Act is preempted by ERISA); Blue Cross and Blue Shield v. Neilsen, 917 F. Supp. 1532, 1542 (N.D. Ala. 1996) (holding that Alabama's Assignment Act, Dental Act, and Pharmacy Act are each preempted by ERISA). However, note that in American Drug Stores v. Harvard Pilgrim Health Care, 973 F. Supp. 60 (D. Mass. 1997), the court held that Massachusetts's any-willingpharmacy-provider law was not preempted by ERISA. See id. at 72 . The court indicated that, unlike statutes that encompassed ERISA plans within their regulation, the statute at hand did not do so. See id. at 65 . In addition, the court did not feel that the statute "relate[d] to" ERISA because it did not mandate employee benefit structures. See id. at 66-69. See generally Larry J. Pittman, "Any Willing Provider" Laws and ERISA's Saving Clause: A New Solution for an Old Problem, 64 TENN. L. REv. 409 (1997) (reviewing states' any-willing-provider laws and arguing for a single standard of assessment using ERISA's saving clause). 
of insurance." 321 Indeed, the statute seems to arise from a foundation of common law tort and breach-of-contract theories that are clearly not within the purview of the saving clause. ${ }^{322}$

Of course, even if the Texas statute were to avoid the difficulties of ERISA preemption, it does not affect the other issues the legal infrastructure has created that directly affect patient care, injury, and liability. As noted previously, the statute does not address the independent contractor shield, ${ }^{323}$ which most likely absolves the MCO of liability in vicarious-liability suits, or the threat of deselection, ${ }^{324}$ which provides the MCO with the viable ammunition it needs to direct physician behavior.

Other efforts on the state level have not directly addressed the legal circumstances that have formed the incentive structures that exist today in the healthcare system. Gag clause legislation, ${ }^{325}$ which attempts to open communications between physicians and patients, does not take into account the threat of deselection and thus is a relatively empty gesture. Since physicians can be fired for advocating, they will not risk their financial lifeline even if gag clause legislation is passed. ${ }^{326}$ Also, state legislation by body part $^{327}$ simply addresses the disease entity at hand by mandating

321. Metropolitan Life Ins. Co., 471 U.S. at 743.

322. See Pilot Life Ins. Co. v. Dedeaux, 481 U.S. 41 (1987):

The state common law of bad faith is therefore no more "integral" to the insurerinsured relationship than any State's general contract law is integral to a contract made in that State... [E]ven if associated with the insurance industry, [the law] has developed from general principles of tort and contract law [and does not regulate the business of insurance].

Id.; see also Gaylor v. John Hancock Mut. Life Ins. Co., 112 F.3d 460, 466 (10th Cir. 1997) (holding that, because Oklahoma's bad faith insurance law originates from general principles of tort and contract law, the saving clause is inapplicable and suits under it are preempted by ERISA); Schachner v. Blue Cross and Blue Shield, 77 F.3d 889, 896-98 (6th Cir. 1996) (finding that a bad faith claim against an insurer is preempted since the state law arose from Ohio tort law); Spain v. Aetna Life Ins. Co., 11 F.3d 129, 132 (9th Cir. 1993) ("The cause of action for wrongful death at issue in this appeal is a general tort and clearly was not specifically tailored by the state to regulate insurance, banking, or securities [and is thus preempted]."); Norton v. North Georgia Foods, 440 S.E.2d 263, 266 n.2 (Ga. Ct. App. 1994) (stating that the insurance law exception in ERISA's saving clause is not applicable to general tort claims that merely affect insurance companies).

323. See supra Section II.A (discussing the independent contractor shield).

324. See supra Section II.B (discussing deselection).

325. Gag clauses are those clauses that limit the extent to which physicians may communicate with their patients. The clauses proscribe communication on topics such as the nature or level of medically appropriate care, care that is in the best interest of the patient but is not covered by the health plan, and experimental treatment. See Julie V. King \& Bryan A. Liang, The Silencing of the Physician: Gag Rules in a Managed Care Environment, HOSP. PHYSICIAN, July 1998, at 64; Liang, Gag Clause Legislation, supra note 268.

326. See King \& Liang, supra note 325, at 65, 68; Liang, Malpractice Burden, supra note 269 , at 6.

327. "Legislation by body part" refers to efforts to require, for example, minimum lengths 
hospital stays and does not address actual medical necessity; indeed, it may mandate a level of care that may not be appropriate now or in the future. In addition, these proposals may put additional pressure on physicians to limit costs elsewhere to mitigate the negative financial effects of state mandates for hospitalization. Other state proposals that focus on disclosure of financial incentives, ${ }^{328}$ denial-of-treatment appeals mechanisms, ${ }^{329}$ emergency care, ${ }^{330}$ and so forth suffer from the same limitations of the Texas statute. Also, none of the state efforts addresses the independent contractor shield. Most importantly, the vast majority of these efforts, even if they were effective, would not survive the preemption provision of ERISA if they attempted to reach ERISA EBPs, and thus would have only minor impact if enacted. ${ }^{331}$

\section{B. Federal Proposals-Theme Two: Eliminate the ERISA Shield}

At present, no federal law has been enacted that addresses the incentive difficulties involving ERISA, independent contractor law, or deselection. Federal efforts to address managed care that have become law have focused unevenly on disclosure of physicians' financial incentives. For example, the most recently finalized regulations on financial incentives in managed care govern incentive plans between MCOs and physicians. ${ }^{332}$ However, these regulations apply only to Medicare and Medicaid beneficiaries $;{ }^{333}$ moreover, while the MCO must give a detailed disclosure to the

of stay or treatment for specific diagnoses, such as a 48-hour stay for the mother after a vaginal birth, a 96-hour stay for the mother after a Cesarean-section birth, and a 24-hour stay for a patient after a mastectomy. See ARIz. REV. STAT. ANN. \$ 20-1057(S) (West Supp. 1997); 215 ILL. Comp. Stat. ANN. 5/356t (West Supp. 1998); IOWA CodE ANN. \& 514C.12 (West 1997); Mo. ANN. STAT. \$ 376.1210 (West Supp. 1998); N.M. STAT. ANN. \$ 59A-46-41(A) (Michie Supp. 1998); 40 PA. Cons. STAT. ANN. $\$ 1583$ (West Supp. 1998); R.I. GEN. LAws $\$ 27-20-29.1$ (Michie Supp. 1997); W. VA. CODE ANN. $\$ 33-15-4$ e (Michie Supp. 1998). Congress has also entered into this mode of policymaking. See infra note 335 .

328. See, e.g., H.B. 1927, 181st Gen. Ct., Reg. Sess. (Mass. 1997); S.B. 269, 207th Leg., 1st Annual Sess. (N.J. 1996); H.B. 3116, 100th Gen. Assem., Reg. Sess. (Tenn. 1998).

329. See, e.g., H.B. 626, 90th Gen. Assem., Reg. Sess. (Ill. 1997); S.B. 365, 55th Leg., Reg. Sess. (Mont. 1997); S.B. 383, 75th Leg., Reg. Sess. (Tex. 1997).

330. See, e.g., H.B. 3163, 19th Leg., Reg. Sess. (Haw. 1998); S.B. 364, 110th Gen. Assem., 2d Reg. Sess. (Ind. 1998); H.B. 129, Gen. Ct., Reg. Sess. (N.H. 1997).

331. See Emily Roskey, Laws Expanding Health Plan Liability Pose Challenge to ERISA Preemption, 3 Managed Care Rep. (BNA) 1158, 1160 (Dec. 17, 1997) ("In any state, any impact of state legislation expanding insurer liability also is likely to be mitigated because such laws apply to few plans as a result of the ERISA preemption.").

332. Requirements for Physician Incentive Plans in Prepaid Health Care Organizations, 61 Fed. Reg. 69,034 (1996) (codified primarily at 42 C.F.R. $\$ 417.479$ ) [hereinafter Physician Incentive Plans].

333. See id. This is not unusual; measures considered in Congress consistently focus on Medicaid and Medicare beneficiaries, especially the latter. See, e.g., S. 789, 105th Cong. (1997) (proposing to amend the Social Security Act to provide Medicare beneficiaries with additional, comparative information regarding Medicare managed care plans and Medicare select insur- 
Health Care Financing Administration and state Medicaid agencies, ${ }^{334}$ its obligation to the beneficiaries requires only a general disclosure to those who request the information. Some other federal efforts to regulate managed care are similar to state legislation-by-body-part efforts. ${ }^{33}$

Several bills that were introduced in the last Congress, however, directly addressed the ERISA MCO shield. Congress focused on Representative Charles Norwood's two bills that explicitly removed ERISA protections for injury caused by MCO decisionmaking. ${ }^{336}$ One of the bills provided, in part, as follows:

(a) In General - Section 514(b) of the Employee Retirement Income Security Act of 1974 (29 U.S.C.A. § 1144(b)) is amended--

(1) by redesignating paragraph (9) as paragraph (10); and

(2) by inserting after paragraph (8) the following new paragraph:

(9)(A) Subsection (a) shall not apply to any cause of action to recover damages for personal or financial injury or wrongful death against any person that provides insurance or administrative services to or for an employee welfare benefit plan maintained to provide healthcare benefits.

'(B) Subparagraph (A) shall not apply to any cause of action against an employer or other plan sponsor unless-

'(i) the employer or other plan sponsor exercised discretionary authority to review and make decisions on claims for plan benefits, and

ance policies); S. 701, 105th Cong. (1997) (proposing to amend the Social Security Act to assure Medicare beneficiaries access to medically necessary treatment, grievance processes, and explanations of benefits comparisons between plans); H.R. 459, 105th Cong. (1997) (proposing to amend the Social Security Act to assure that Medicare HMOs provide out-of-network services to Medicare beneficiaries); H.R. 66, 105th Cong. (1997) (proposing additional protections and MCO disclosures for Medicare beneficiaries); S. 864, 105th Cong. (1997) (proposing to amend the Social Security Act to provide access to managed care by Medicaid beneficiaries and mandating quality assurance programs that include an annual independent, external review of MCOs).

334. See Physician Incentive Plan, supra note 332.

335. See, e.g., Newborns' and Mothers' Health Protection Act of 1996, Pub. L. No. 104-204, 110 Stat. 2874, 2935 (1996) (mandating minimum in-patient hospitalization coverage of 48 hours after a vaginal birth and 96 hours after a Cesarean section birth); see also Breast Cancer Patient Protection Act of 1997, S. 143, 105th Cong. (1997) (proposing mandatory minimum hospital stays for women who undergo mastectomies).

336. See Patient Access to Responsible Care Act of 1997 (PARCA), H.R. 1415, 105th Cong. (1997); Responsibility in Managed Care Act of 1997, H.R. 2960, 105th Cong. (1997). Norwood's bills contain similar provisions regarding ERISA and MCOs. PARCA was one of the most widely supported proposals that addressed the incentive problems in healthcare delivery, with 232 sponsors. See Bill Tracking Service H.R. 1415, available in LEXIS, Legis library, Bitrck file. Norwood plans to reintroduce patient protections in the 106th Congress. See $\mathrm{Pa}$ tients' Bill of Rights All But Dead as 105th Congress Heads into Final Days, 7 Health L. Rep. (BNA) 1597, 1597 (Oct. 9, 1998). 
'(ii) the exercise by such employer or other plan sponsor of such authority resulted in personal or financial injury or wrongful death.

'(C) A person that provides insurance or administrative services to or for an employee welfare benefit plan shall not have a right of recovery or indemnity against an employer or other plan sponsor for damages recovered pursuant to a cause of action referred to in subparagraph (A)., ${ }^{337}$

With this proposal, Representative Norwood attempted to remove the ERISA shield from MCOs by expressly permitting tort and other claims based on personal or financial injury arising out of an EBP's insurance or administrative services. Employers, unless they retained a fiduciary's discretionary authority to make determinations of health coverage, ${ }^{338}$ were not reachable directly or by indemnification. ${ }^{339}$

Although this proposal was laudable as an effort to address the ERISA MCO shield, it is problematic. First, it did not address the important problems of the MCO independent contractor shield and deselection. ${ }^{340}$ Even if passed, therefore, there would have been some question as to whether it would have achieved the goal of focusing the health delivery system on patient care. Second, it inappropriately focused only on the statute's preemption provision; for direct MCO liability, the civil enforcement provision, section 502, has proven the most problematic for

337. H.R. $2960 \S 2$.

338. ERISA permits employers to have this role. Generally, an entity will be a fiduciary under ERISA to the extent that it has or can exercise discretionary responsibility or authority in the administration of the plan. See 29 U.S.C. $\$ 1002(21)$ (A) (1994). The MCO may be assigned the role of plan fiduciary, but the employer may also retain this role. An entity's responsibilities with regard to the plan, not a title or formal designation, dictate whether or not it is a fiduciary. See Donovan v. Mercer, 747 F.2d 304 (5th Cir. 1984); see also supra note 45 (discussing standards of review for administrators given discretionary authority).

339. Representative Pallone, in his Health Care Consumer Protection Act of 1997, H.R. 3009 , 105th Cong. (1997), mandated coverage, see id. sec. 105, § 2775, information, see id. sec. $301, \S 2780$, and access requirements, see id. sec. $102, \S 2771$, and proposed to amend ERISA to allow for state causes of action for personal injury and/or wrongful death, see id. sec. 204(a). Like Representative Norwood's bill, see H.R. 1415 sec. 2(a)(3), \$2777(a)(11), Pallone's proposal would have prohibited termination-without-cause clauses in provider contracts, see H.R. 3009 sec. 203, $\$ 2779(a)(11)$. However, Representative Pallone's proposal had only 31 cosponsors in the House and suffered from the same limitations as Representative Norwood's proposal. See Bill Tracking Service H.R. 3009, available in LEXIS, Legis library, Bltrck file; infra notes 340-342 and accompanying text (criticizing the Norwood proposal).

340. Norwood's H.R. 2960 was limited to the ERISA issue exclusively. However, PARCA addressed the independent contractor issue by prohibiting termination-without-cause clauses in provider contracts. PARCA's proposed $\$ 2777$ of the Public Health Services Act indicated that a health insurance issuer, with respect to its offering of network coverage, shall "not include in its contracts with participating health professionals and providers a provision permitting the issuer to terminate the contract "without cause" and shall "provide a due process appeal that conforms to the process specified in section 412 of the Health Care Quality Improvement Act of 1986 [42 U.S.C. $\S 11112(1994)]$ for all determinations that are adverse to a health professional or provider." PARCA, H.R. $1415 \S 2$. 
beneficiaries attempting to gain a hearing on the merits. ${ }^{341}$ In addition, the current, major court battles involving section 514 are about indirect state-law causes of action against MCOs, not attempts to hold them directly liable. The proposed statute, however, was silent on these claims and therefore did not resolve the significant split in the federal courts regarding the applicability of ERISA's preemption provision to indirect claims. $^{342}$

ERISA was implicated in a variety of other federal proposals. ${ }^{343}$ Representative Roukema proposed a bill, the Quality Health Care and Consumer Protection Act, ${ }^{344}$ that would have directly amended ERISA and required that MCOs provide access to appropriate personnel, facilities, ${ }^{345}$ drugs, and devices; ${ }^{346}$ prohibit gag clauses; ${ }^{347}$ establish appropriate quality assurance programs; ${ }^{348}$ publish plan information and data; $;^{349}$ disclose the MCO medical director's financial remuneration; ${ }^{350}$ and provide for enrollee notice of all grievance procedures and appeals. ${ }^{351}$ Representative Schumer's proposal, the Health Insurance Consumer's Bill of Rights Act of $1997,{ }^{352}$ would also have required MCOs to meet certain personnel, ac-

341. See supra Sections I.B-C (discussing, in part, ERISA's civil enforcement provision and its effects upon MCO liability).

342. See supra Section I.H (discussing indirect claims cases and ERISA preemption).

343. Other bills with much less support did not effectively address the problems created by the current legal infrastructure. See, e.g., Managed Care Consumer Protection Act of 1997, H.R. 337, 105th Cong. (1997) (attempting to use the tax system to penalize MCOs for not comporting with new federal standards, including those with regard to enrollee access, utilization review, grievance procedures, physician incentive disclosure, childbirth benefits, gag clause prohibition, and discrimination); the Health Insurance Bill of Rights Act of 1997, H.R. 820, 105th Cong. (1997) (amending the Public Health Service Act (PHSA) to provide, among other things, for women to have direct access to obstetricians-gynecologists as primary care providers; direct access and standing referrals for specialists, if needed; transitional access to a terminated/deselected provider; mandatory data collection; and a prohibition on gag clauses and to permit state laws that impose even more stringent mandates than those required by the bill); the Comprehensive Managed Health Care Reform Act of 1997, H.R. 2905, 105th Cong. (1997) (mandating personnel, general service levels, incentive structures, information requirements, and medical loss ratios for MCOs). These bills had few co-sponsors and did not address the main issues of ERISA, independent contractor law, and deselection difficulties. Although these proposals enjoyed the benefit of applying to participants of all MCOs rather only Medicare and Medicaid beneficiaries, they would have little effect on the important incentive structures in the healthcare delivery system.

344. H.R. 1222, 105th Cong. (1997).

345. See id. sec. $3, \$ 713(\mathrm{a})$.

346. See id. $\$ 713(\mathrm{~d})$.

347. See id. \$713(c).

348. See id. $\$ 713(\mathrm{f})$.

349. See id. \$713(g).

350. See id. $\$ 713(\mathrm{~h})$.

351. See id. $\$ 713(\mathrm{i})$.

352. H.R. 2967, 105th Cong. (1997). This bill was identical to S. 1499, 105th Cong. (1997), which was introduced by Senator Boxer. 
cess, coverage, and informational standards. ${ }^{353}$ That bill, like the Roukema proposal, would have amended ERISA to mandate that these rights be extended to ERISA EBPs. ${ }^{354}$ In addition, Representative Stark proposed the Managed Care Plan Accountability Act of $1997^{355}$ which, in concert with his other proposal, ${ }^{356}$ would have imposed excise taxes on MCOs that failed to provide benefits according to the terms of coverage if the failure was due to any cost-containment technique, including utilization review, or any restriction on a provider's discretion. ${ }^{357}$ Also, this bill would have amended ERISA's civil enforcement provision to establish joint and several liability in federal actions for actual damages (both compensatory and consequential) for an injury resulting from such costsaving techniques and restrictions. ${ }^{358}$ Representative Velazquez introduced a similar bill that would have expressly eliminated ERISA preemption of state causes of action for wrongful death or personal injury. ${ }^{359}$

These four proposals, however, would not have adequately addressed the incentive structure in healthcare today. First, the low number of sponsors they gathered indicates that, if they are reintroduced in the next Congress, passage is unlikely and support is not broad. ${ }^{360}$ Second, only the Stark and Velazquez bills would have extended liability to ERISA MCOs, ${ }^{361}$ and even these proposals, like the Norwood bills, account for

353. See H.R. 2967 sec. 101, §§ 2771-2778, 2786.

354. See id. $\$ 202$. The bill also would have amended the Health Insurance Portability and Accountability Act of 1996, see id. $\$ 201$, and the Social Security Act, see id. $\$ 204$.

355. H.R. 1749, 105th Cong. (1997).

356. H.R. 337, 105th Cong. (1997) (proposing to use the federal tax system to penalize MCOs for not comporting with proposed federal standards with regard to enrollee access, utilization review, grievance procedures, physician incentive disclosure, childbirth benefits, gag clause prohibition, and entollee discrimination).

357. See H.R. $1749 \$ 3$.

358. See id. $\sec 3, \$ 502$ (c)(6)(A).

359. See Managed Care Bill of Rights for Consumers Act of 1997, H.R. 2606, 105th Cong. $\S$ 4 (1997).

360. H.R. 1222 had only one co-sponsor. See Bill Tracking Service H.R. 1222, available in LEXIS, Legis library, Bltrck file. H.R. 1749 had only 31 co-sponsors, and none was a Republican. See Bill Tracking Service H.R. 1749, available in LEXIS, Legis library, Bltrck file. H.R. 2606 had only 24 co-sponsors, with no Republicans. See Bill Tracking Service H.R. 2606, available in LEXIS, Legis library, Bltrck file. H.R. 2905 (1997) had only three co-sponsors, with no Republicans. See Bill Tracking Service H.R. 2905, available in LEXIS, Legis library, Bltrck file. H.R. 2967 had no co-sponsors. See Bill Tracking Service H.R. 2967, available in LEXIS, Legis library, Bltrck file.

361. H.R. 1749 would, however, be an improvement over the Norwood proposals because it expressly amends ERISA's civil enforcement provision, see H.R. 1749 \$2, while Representative Norwood's bills focus on the preemption provision, see H.R. 2960 \&. This might eliminate ambiguity with regard to denial-of-benefits claims and other claims that fall within the statute's civil enforcement provision and are thereby completely preempted under current law. See supra Section I.C (discussing complete preemption under ERISA). The Velazquez bill amended the preemption provision, see H.R. $2606 \S 4$, and thus suffered from the same limitations as the 
neither the significant MCO protection arising from the common law of independent contractors nor the difficulties of deselection. Even if passed, these proposals would only lead to limited change in the landscape of health delivery, patient injury levels, and MCO accountability.

Finally, the Democratic and Republican leadership created their own competing bills. The Democrats' Patients' Bill of Rights ${ }^{362}$ and the Republicans' Patient Protection Act $^{363}$ both contained provisions drawn from other bills, including mandates for patient appeals mechanisms, direct access to some specialists, prohibition of gag clauses, MCO disclosure requirements, and emergency treatment mandates. The Democrats' plan provided for a right to sue ERISA MCOs for damages caused by denials of coverage, ${ }^{364}$ whereas the Republican plan provides only for fines of $\$ 500$ per day for denials of medically necessary care (up to a limit of $\$ 250,000) .^{365}$ The Democrats' plan was defeated when brought to the House floor. The Republican plan passed the House by a slim margin, ${ }^{366}$ but the President threatened to veto it. ${ }^{367}$ Regardless of the partisan wrangling over the right to sue, neither bill addressed the difficulties associated with the independent contractor shield or problems related to termination without cause. Ultimately, of course, no healthcare reform bill passed both houses in the 105th Congress.

Overall, none of the recent state or federal proposals directly addresses the legally created incentive system that currently frames the healthcare delivery infrastructure. Enacting access, personnel, and informational requirements using vague language ${ }^{368}$ will not substantively af-

Norwood proposals.

362. H.R. 3605, 105th Cong. (1998).

363. H.R. 4250, 105th Cong. (1998).

364. See H.R. $3605 \$ 302$.

365. See H.R. $4250 \$ 1201$ (b). Daily fines under the bill could be increased to $\$ 1000$ for bad-faith denials. See id.

366. The House of Representatives defeated the Democrat's bill by a vote of $212-217$ and passed the Republican measure 216-210. See David Nather, House Passes GOP Managed Care Bill; Clinton Administration Threatens Veto, 4 Managed Care Rep. (BNA) 761, 761 (July 29, 1998).

367. See id.

368. Consider the following examples of vague language. "A managed care group health plan ... [shall] have a sufficient number and type of primary care practitioners and specialists, throughout the service area to meet the needs of enrollees and to provide meaningful choice . ..." H.R. 2967, 105th Cong. sec. 101, \$ 2771(1) (1997). "The provisions of any contract or agreement, or the operation of any contract or agreement, between a group health plan or health insurance issuer ... and a health professional shall not prohibit or restrict the health professional from engaging in medical communications with his or her patient." Id. $\$ 2776$ (a). "A health insurance issuer ... may not impose limits on the manner in which particular services are delivered if the services are medically necessary and appropriate for the treatment or diagnosis of an illness or injury..." Health Insurance Bill of Rights Act, S. 353, 105th Cong. sec. 2, $\S 2789$ (a) (1997). "The [quality] program provides for the collection of systematic, scientifically 
fect how care is delivered because the incentives of the parties will be changed little under any of these proposals.

\section{Aligning InCENTIVES: A Proposal}

This Article's assessment of the legal system as it relates to patient injury suits in the context of managed care has thus far shown that ERISA, independent contractor law, and deselection are the critical issues that need to be addressed if the incentives of the system are to be aligned toward patient care. This Part presents a federal legislative proposal that directly addresses these legal concerns. This Part also recognizes that there is a policy debate regarding the possible increase in costs due to reforms such as those proposed here and argues that these cost increases can be mitigated by current legislative efforts that facilitate group purchasing for adversely affected parties. In combination, this proposal and group purchasing reforms that are being debated in Congress represent a viable solution to the inequities within the healthcare delivery system.

\section{A. A Bill}

Current legislative efforts do not adequately address the critical aspects of law that have created a uniquely detrimental set of incentives for patient injury in the healthcare delivery system. In order for substantive incentive changes to occur, the problems of ERISA, the common law of independent contractors as applied to MCOs, and the unchallengeability of termination-without-cause clauses in managed care contracts must be addressed together.

Statutory reform must come at the federal level to avoid preemption by ERISA and fragmentation of beneficiaries' rights across state lines. Congressional legislation containing the following provisions would accomplish these goals:

\section{A Bill}

To amend Title I of the Employee Retirement Income Security Act of 1974 and the Public Health Service Act to provide aligned incentives for patient care in the health delivery system, and for other purposes.

Be it enacted by the Senate and the House of Representatives of the United States of America in Congress assembled,

\footnotetext{
based data to be used in the measure of quality." H.R. 820, 105th Cong. sec. 2(a), $\$ 2777$ (b)(6) (1997). "A managed care group health plan ... shall not have any contract provision with a healthcare professional that limits the healthcare professional's disclosure to an enrollee ... of any information relating to the enrollee's medical condition or treatment options...." H.R. 1222, 105th Cong. sec. 3, \& 713(c)(1) (1997).
} 
Section 1. Short Title.

The Act may be cited as the "Aligning Incentives for Patient Care Act."

Section 2. Purpose.

The purpose of this Act is to-

(1) amend the Employee Retirement Income Security Act of 1974 so that it does not preempt State-law causes of action for damages for personal or financial injury or wrongful death resulting from failure to provide or negligent provision or arrangement of benefits under employee welfare benefit plans providing healthcare benefits;

(2) recognize that medical decisionmaking now includes managed care and other organizations as well as traditional medical providers, that the traditional independent contractor status of providers is inapplicable to current healthcare delivery, and that each of these parties, as participants in the medical decisionmaking process, must be held accountable for wrongful patient injury;

(3) recognize that medical providers are the primary patient advocates and that managed care or other organizational use of termination-withoutcause clauses in medical provider contracts is detrimental to the full and effective performance of this role and should be eliminated as harmful to patient care; and

(4) recognize that these enumerated problems and their solutions must be addressed together for substantive protection of patients.

The "purpose" section of this bill expresses the need for coordinated reform of the three critical legal areas that have created the problematic set of incentives in the current health delivery structure. This will make the interpretation and regulatory implementation of the statute more likely to reflect the concerns that the statute was drafted to address.

With regard to the ERISA issue, the following language could address both the difficulties of preemption and the independent contractor shield:

Section 3. Preservation of certain state causes of action against ERISA preemption and healthcare provider status in ERISA plans.

(a) In General.-Section 502(a) of the Employee Retirement Income Security Act of 1974 (29 U.S.C.A. \& 1132(a)(1) (West 1985 \& Supp. 1998)) is amended by inserting after subparagraph (B) the following new subparagraphs:

"(C) Subparagraph (B) shall not apply to limit any cause of action, direct or indirect, to recover damages for personal or financial injury or wrongful death against any entity, including a medical provider or managed care or other organization which provides medical care services, administrative services, or insurance to or for an employee welfare bene- 
fit plan maintained to provide healthcare benefits, that results from failure to provide or negligent provision or negligent arrangement of benefits.

"(D) Subparagraph (C) shall not apply to any cause of action against an employer or other plan sponsor unless-

"(i) the employer or other plan sponsor exercised discretionary authority to review and make decisions on claims for benefits, and

"(ii) the exercise by such employer or other plan sponsor of such authority resulted in personal or financial injury or wrongful death.

"(E) An entity that provides insurance or administrative services to or for an employee welfare benefit plan shall not have a right of recovery or indemnity against an employer or other plan sponsor for damages recovered pursuant to a cause of action referred to in subparagraph (C) unless subparagraphs (D)(i) and (D)(ii) apply.

"(F) For the purposes of this title, independent contractor medical providers shall be deemed "independent employees" of the organizations with whom they contract, and shall have the status as employees of any organization indicated in subparagraphs $(C),(D)$, and $(E)$ and for the purposes of civil actions indicated in subparagraphs (C), (D), and (E)."

(b) Application to other preemption provision.-Section 514(b) of the Employee Retirement Income Security Act of 1974 (29 U.S.C.A. \& 1144(b) (West 1985 \& Supp. 1998)) is amended-

(1) by redesignating paragraph (9) as paragraph (10); and

(2) inserting after paragraph (8) the following new paragraph:

"(9) Subsection (a) of this section shall not apply with respect to any cause of action indicated in Sections 502(1)(C)-(E) of this Act."

First, ERISA is amended in subsection (a) to exempt common law actions for damages from preemption by the statute's civil enforcement provision. By indicating specifically that managed care and other organizations are within the purview of the statute and that liability can attach for denial of benefits, the complete preemption doctrine under section 502 will not prevent civil damage actions for inappropriate denials of care. This will help eliminate the incentive for MCOs to simply deny care. In addition, by also exempting from preemption suits for negligent provision or arrangement of services, Dukes is effectively codified. Thus, courts addressing the issue will not consider direct "quality" of care suits against MCOs to be preempted by ERISA.

Proposed subparagraph (D) also addresses an incentive issue relevant to ERISA. It is important that the actual decisionmakers involved in authorizing or denying healthcare benefits face liability. Employers often set up EBPs for the benefit of their employees but then do not exercise 
administrative decisionmaking as to what care will be authorized or denied. These employers should not be saddled with liability because they do not participate in or control the medical decisionmaking process. If the employers were subject to liability, they would, in effect, be the indemnifier for the actual decisionmaker, the MCO. However, if the employers do retain the decisionmaking capacity and act to approve or disapprove requests for care, they should be liable. ${ }^{369}$ Proposed subparagraph (D) takes these considerations into account by generally excluding employers from the liability provision unless they are part of the healthcare delivery decisionmaking process. Similarly, proposed subparagraph (E) limits the ability of the MCO to use the employer as an insurer to instances where the employer did indeed exercise authority over providing or denying benefits in the plan.

Proposed subparagraph (F) addresses the independent contractor shield. By creating a new "independent employee" status for contracting physicians, medical providers would be recognized in the world of managed care for what they are: a hybrid form of employee and independent contractor who remains under the control of the MCO "on the most practical of all bases-financial." ${ }^{, 370}$ By treating the medical provider as an employee, both major decisionmaking parties will have an incentive to provide the appropriate amount of care and thereby avoid patient injury. In this way, incentives of these parties become aligned. ${ }^{371}$

Subsection (b) indicates that the amendments to the civil enforcement provision are also applicable to the statute's preemption provision. This solves two of the more contentious legal issues in the field of ERISA preemption: First, applying proposed subparagraph $(a)(1)(C)$ of the civil enforcement clause-which expressly permits both direct and indirect causes of action-to the preemption clause resolves the conflict in the courts as to whether the preemption clause reaches vicarious-liability and ostensible-agency claims; second, the difficulties courts have exhibited with regard to exercising jurisdiction over the cases and the potential

369. Generally, these considerations are based upon whether the employer retains the role of fiduciary for the plan. See supra note 338 (discussing plan fiduciaries).

370. Liang, Deselection, supra note 46 , at 854.

371. Note that, although holding liable both the medical provider and the MCO is similar to enterprise liability, it is actually an extension of the concept, because enterprise liability is generally applicable only to traditional employee physicians. See Clark C. Havighurst, Making Health Plans Accountable for the Quality of Care, 31 GA. L. REV. 587 (1997); Jack K. Kilcullen, Groping for the Reins: ERISA, HMO Malpractice, and Enterprise Liability, 22 AM. J.L. \& MED. 7, 49 (1996); Liang, Malpractice Burden, supra note 269, at 6; Kent G. Rutter, Democratizing HMO Regulation to Enforce the 'Rule of Rescue', 30 U. MrCH. J.L. REFORM 147, 169 (1997); James S. Todd, Reform of the Health Care System and Professional Liability, 329 NEw ENG. J. MED. 1733 (1993); see also Patricia M. Danzon, Tort Liability: A Minefield for Managed Care?, 26 J. LEGAL STUD. 491, 517-18 (1997) (arguing for similar accountability in both ERISA and non-ERISA plans). 
void nature of these decisions would be eliminated, because the statute expressly allows for such suits, indicates they are not preempted by ERISA, and does not require consideration of complete versus conflict preemption in their adjudication.

Although much of this Article's discussion revolves around the great number of ERISA beneficiaries, the managed care revolution has also touched those who do not obtain their benefits through ERISA EBPs yet still access their healthcare through MCOs. These individuals do not have the ERISA shield to bar their claims; however, they do have the independent contractor shield with which to contend. To extend the bill's recognition of the modern healthcare context to all patients, the following provision is important:

Section 4. Patient protection and medical provider standards under the Public Health Service Act.

Title XXVII of the Public Health Service Act is amended-

(1) by redesignating part $C$ as part $D$, and

(2) by inserting after part $B$ the following new paragraphs:

“(C)(1) For the purposes of this Act, independent contractor medical providers shall be deemed "independent employees" of the organizations with whom they contract, and shall have the status as employees in any civil suits to recover damages for personal or financial injury or wrongful death against any entity, including a medical provider or managed care or other organization, directly or indirectly, that provides or arranges for medical care services.

"(2) A managed care or other organization with regard to contracting for medical providers shall-

"(a) not include in its contracts with medical providers a provision permitting the managed care or other organization to terminate the contract "without cause"; and

"(b) provide, unless the medical provider poses an imminent harm to patients,-

"(i) reasonable notice of any decision to terminate a medical provider "for cause," including a written explanation of the reasons for termination;

"(ii) an opportunity to review and discuss all of the information on which the determination is based; and

"(iii) a due process appeal procedure that conforms with the process specified in section 412 of the Health Care Quality Improvement Act of 1986 (42 U.S.C. $\$ 11112$ (1994)).

“(3) The provisions in paragraph (2) shall also apply to all managed 
care and other organizations providing medical care services, administrative services, or insurance to or for an employee welfare benefit plan maintained to provide healthcare benefits which are governed by the Employee Retirement Income Security Act of 1974 (29 U.S.C.A. \$§ 1001-1461. (West 1985 \& Supp. 1998))."

By amending the Public Health Service Act, paragraph (1) provides the independent employee protection to patients who obtain their healthcare from non-ERISA MCOs and an aligned incentive structure for the key medical decisionmakers in these plans.

In addition, paragraphs (2) and (3) address the issue of deselection. By eliminating the use of termination-without-cause clauses, medical providers in non-ERISA plans (paragraph (2)) and ERISA plans (paragraph (3)) will be able to advocate for their patients effectively through frank discussion ${ }^{372}$ and to consider all medically appropriate alternatives without the fear of a without-cause termination. Further, the section requires reasonable due process for providers who are terminated with cause. This provision is important because the notice and hearing requirements under the Health Care Quality Improvement Act of 1986 are well defined, provide for a written record of the proceedings, and thus allow a medical provider to be assessed in an open forum. ${ }^{373}$ This

372. Indeed, much of the "gag clause" legislation on both the state and federal level lacks substantive impact due to a lack of consideration of the deselection problem. See Liang, Gag Clause Legislation, supra note 268.

373. See 42 U.S.C. $\$ 11112$ (b)(3)(C)(ii) (1994). The due process provisions of the Health Care Quality Improvement Act of 1986 are applicable to all providers who participate in peer review activities as well as the healthcare entity through which they practice. Section 412 of the Act, entitled "Standards for Professional Review Actions," provides, in part, as follows:

(b) Adequate notice and hearing [requirement]

A healthcare entity is deemed to have met the adequate notice and hearing requirement of subsection (a)(3) of this section with respect to a physician if the following conditions are met (or are waived voluntarily by the physician):

(1) Notice of proposed action

The physician has been given notice stating-

(A)(i) that a professional review action has been proposed to be taken against the physician,

(ii) reasons for the proposed action,

(B)(i) that the physician has the right to request a hearing on the proposed action,

(ii) any time limit (of not less than 30 days) within which to request such a hearing, and

(C) a summary of the rights in the hearing under paragraph (3).

(2) Notice of hearing

If a hearing is requested on a timely basis under paragraph $(1)(B)$, the physician involved must be given notice stating-

(A) the place, time, and date, of the hearing, which date shall not be less than 30 days after the date of the notice, and

(B) a list of the witnesses (if any) expected to testify at the hearing on behalf of the professional review body. 
open forum will allow patients to determine why providers are being terminated and whether those reasons are medically or financially based. This information and forum are, in turn, critical to allowing patients to determine whether the specific MCO, or other competitor MCOs, are focused on care or on costs.

Thus, by statutory means, which are the most efficient, ${ }^{374}$ the incentive structure for the delivery of healthcare in the United States can be sub-

(3) Conduct of hearing and notice

If a hearing is requested on a timely basis under paragraph (1)(B)-

(A) subject to subparagraph (B), the hearing shall be held (as determined by the healthcare entity) -

(i) before an arbitrator mutually acceptable to the physician and the healthcare entity,

(ii) before a hearing officer who is appointed by the entity and who is not in direct economic competition with the physician involved, or

(iii) before a panel of individuals who are appointed by the entity and are not in direct economic competition with the physician involved;

(B) the right to the hearing may be forfeited if the physician fails, without good cause, to appear;

(C) in the hearing the physician involved has the right-

(i) to representation by an attorney or other person of the physician's choice,

(ii) to have a record made of the proceedings, copies of which may be obtained by the physician upon payment of any reasonable charges associated with the preparation thereof,

(iii) to call, examine, and cross-examine witnesses,

(iv) to present evidence determined to be relevant by the hearing officer, regardless of its admissibility in a court of law, and

(v) to submit a written statement at the close of the hearing; and

(D) upon completion of the hearing, the physician involved has the right-

(i) to receive the written recommendation of the arbitrator, officer, or panel, including a statement of the basis for the recommendations, and

(ii) to receive a written decision of the healthcare entity, including a statement of the basis for the decision.

A professional review body's failure to meet the conditions described in this subsection shall not, in itself, constitute failure to meet the standards of subsection (a)(3) of this section.

42 U.S.C. $\$ 11112$ (b) (1994). This provision is essential for another reason. Even if an MCO has had its ERISA shield removed and will face liability, it will still have inappropriate incentives to take care if the joint and several liability that results continues to keep it insulated from the full costs associated with its decisionmaking. If, for example, total patient harm is defined as 100 , and $75 \%$ of this harm is due to inappropriate denial of treatment authorization to the patient, then liability should be 75 . If, however, liability imposed by juries is less than 75 , then the MCO will still have the incentive not to take optimal care. By eliminating deselection, physicians and other medical providers may challenge these attempted care denials, and if the potential liability plus the costs associated with addressing provider complaints increase the costs to the $\mathrm{MCO}$ to 75 , then it will be optimally deterred. See generally RICHARD A. POSNER, ECONOMIC ANALYSIS OF LAW ch. 6 (5th ed. 1998). Of course, an administrative mechanism may also perform these calculations and impose fines to provide optimal deterrence.

374. See Richard A. Epstein, The Social Consequences of Common Law Rules, 95 HARV. L. REV. 1717 (1982) (arguing that legislation is more efficient and effective to achieve social change than is common law). 
stantively changed from one that pits the patient against the MCO (with the physician caught in the middle) to one providing care in the best interests of the patient. This goal will be accomplished primarily through the recognition that, at the time ERISA was passed, there was very little anticipation that costs would explode as they have and managed care would dominate as it has; ${ }^{375}$ that the physician would no longer be the standard independent contractor with unfettered medical decisionmaking discretion; that the market power of MCOs would have made the MCO the medical provider's financial lifeline through which access to patients is provided; and that the patient-physician relationship would be tripartite, with the $\mathrm{MCO}$ an integral player. ${ }^{376}$

\section{B. Costs}

Because the legislative proposal set forth in the preceding Section may cause premiums to rise, employers-particularly small employersmay be tempted to reduce or eliminate healthcare coverage for their employees. $^{377}$ An effective policy for addressing such increased costs, not

375. "[W]hen the Federal Employee Retirement Income Security Act (ERISA) was enacted in 1974, no one envisioned the emergence of managed care plans as the predominant mode of healthcare delivery in the private sector ...." S.J. Res. 168, Reg. Sess. (Va. 1998).

376. The proposed statute is consistent with the original intent of ERISA to provide a single regulatory structure for creating and administering EBPs that does not differ across state lines. All plans and all beneficiaries would have similar access to the courts with similar rules for claim adjudication, rather than the conflicting and varying interpretations of preemption between courts that currently prevail. The key is to allow for uniform access to courts; other considerations, such as the impact of the applicability of various standards for contributory or comparative negligence or local court rules, are not addressed by this proposal.

377. Studies variously estimate that PARCA, H.R. 1415, 105th Cong. (1997), which was the topic of much debate, could raise premiums by as little as $0.5 \%$ to $2.7 \%$ or as much as $7 \%$ to 39\%. See Jerry Geisel, A Fight Against Health Care Bills: Business Groups Say Proposals Would Affect Coverage of Employees, CRAIN's CHI. BUS., Feb. 23, 1998, at SR17 (citing a study finding that PARCA could raise healthcare premiums 7\% to 39\%); NFIB Blasts Federal Health Care Mandates Increasing Premiums, Lowering Coverage, U.S. NEWSWIRE, Jan. 21, 1998, available in 1998 WL 5682350 (citing a study that indicates PARCA would raise premiums 23\%); PARCA Backers' Study Puts Premium Hike at 0.5 to 2.7 Percent, HEALTH LEGIS. \& REG. WEEKLY, Feb. 4, 1998, available in 1998 WL 10395675 (citing a study estimating the increase in premium costs due to PARCA at $0.5 \%$ to $2.7 \%$ ). A cost analysis limited to the provision of PARCA that allows suit against an ERISA MCO indicated a rise in premiums of only $0.0 \%$ to $0.2 \%$. See Muse Study: Details on Providers Show Why PARCA Costs are Lower, MED. \& HEALTH, Feb. 2, 1998, available in 1998 WL 10321250. The increases in premiums associated with the statute this Article proposes would be more akin to this last estimate and would not raise premiums nearly as much as PARCA as a whole because of its relatively limited scope. For example, beyond ERISA preemption and the elimination of termination-without-cause clauses in medical provider contracts, PARCA presents a comprehensive package that contains many other reforms, including mandates for: particular providers in rural health areas, see H.R. 1415 sec. 2(a)(2), $\S 2771$ (a) (amending the Public Health Service Act); a prudent-layperson standard for emergency care coverage, see $i d$. $\$ 2771$ (b); the demonstration of available specialized services, see id. $\$ 2771$ (c); the structure and reporting of incentive plans with medical providers and required 
only in the context of the proposal outlined here but also generally in an environment of increasing healthcare costs, would be to allow small employers to band together to procure insurance as a group, thus providing greater purchasing and negotiating power, lower premiums, and economies of scale when negotiating prices with $\mathrm{MCOs} .{ }^{378}$ Although this idea is not new, previous ERISA-governed group purchasing plans, known as Multiple Employer Welfare Arrangements (MEWAs), were plagued by fraud. ${ }^{379}$ An extensive legislative response resulted in both state and federal regulation of MEWAs and thus significantly dampened the enthusiasm for this mechanism for providing benefits to employees. ${ }^{380}$

stop-loss insurance levels, see id. $\$ 2771(\mathrm{~d})$; a point-of-service plan that provides for coverage for services and providers not available in the plan, see id. $\$ 2772$ (b); direct access to specialists under certain conditions, see id. $\$ 2772$ (c); nondiscrimination against enrollees and medical providers, see id. $\$ 2773$; a prohibition on gag clauses, see id. $\$ 2774$; participants and subject matter for developing plan policies, see id. $\$ 2775$; due process procedures for enrollees that include physician participation and prescribed times for utilization review decisions, see id. $\$ 2776$ (a); appeals process mechanisms for utilization review, see id. \$2776(b); due process provisions for medical provider application, retention, and termination, see id. $\$ 2777$; information reporting and disclosure to patients, see id. $\$ 2778$; confidentiality provisions, see id. $\$ 2779$ (a); health plan financial reserve requirements, see id. $\$ 2779(\mathrm{~b})$; and the type and function of qualityimprovement programs, see id. $\S 2780$. PARCA also allows state regulations that are equivalent to or stricter than those in PARCA, see id. sec. 2(d)(1).

378. History does indeed repeat itself. In the late 1970 s and 1980 s, the same concerns about escalating healthcare costs raised the possibility that small employers would drop healthcare coverage for their employees and dependents. See Bruce D. Pingree, MEWA Regulation, Q219 ALI-ABA 263, 268 (1993) available in Westlaw, ALI-ABA datebase.

379. See, e.g., David C. Aspinwall, Fraudulent Practices Involving the Undenwriting of Group Health Plans, 62 DEF. Couns. J. 249 (1995); Robin Elizabeth Margolis, Are MEWAs Exempt From State Regulation?, HEALTHSPAN, Oct. 1993, at 28, 28-29; Robin Elizabeth Margolis, Multiple Employer Welfare Arrangements: Health Insurance Black Holes, HEALTHSPAN, Apr. 1992, at 18, 18-19; Pingree, supra note 378.

380. MEWAs are employee welfare benefit plans or other arrangements established to provide benefits to the employees of at least two employers. See 29 U.S.C. $\$ 1002$ (40)(A) (1994). However, because ERISA did not originally provide for financial requirements for MEWAs, and because the deemer clause prohibited states from imposing such requirements, MEWAs were effectively not regulated-a circumstance that resulted in plan failures and financial debacles. See Lee Russ, Laws Regulating Multiple Employer Welfare Arrangements, in 1 CoUCH ON INs. $\$ 7: 37$ (3d. ed. 1997). Congress reacted to these problems in 1983, when it allowed certain types of state regulation of MEWAs by adding to ERISA section 514(b)(6). See 29 U.S.C. $\$ 1144$ (b)(6). Under this section, if the MEWA is fully insured, the state is permitted to regulate reserve and contribution requirements; if the MEWA is only partially insured, all state insurance law that is not inconsistent with ERISA is permissible. The Secretary of Labor has the power to exempt partially insured plans from state insurance regulation, but no such exemption has ever been granted. See id.; Michael J. Canan \& William D. Mitchell, Employee Fringe and Welfare Benefit Plans, in EMPLOYEE FRINGE \& WELFARE BENEFIT PLANS \$ 8.3 n.30 (1997). Thus, both states and the federal government actively regulate MEWAs, making the MEWA a relatively undesirable alternative for small business owners and others. See also infra note 407 (noting higher health insurance costs for small businesses due to an inability to selfinsure). 


\section{Patient Injury Incentives}

The basic concept of allowing group purchasing is still a sound one. MEWAs have the significant advantage of obtaining rates that are twenty-five percent to forty percent lower than those charged for traditional group health coverage. ${ }^{381}$ Further, these group-purchasing efforts are particularly important for small employers due to insurance underwriting standards that eschew employers with fewer than 100 employees. ${ }^{352}$ Thus, efforts to take advantage of group purchasing may be a reasonable way to minimize costs and maximize healthcare coverage. ${ }^{383}$

There have been legislative efforts that recognize the benefits of such group purchasing. Representative Fawell introduced the Expansion of Portability and Health Insurance Coverage Act of $1997,{ }^{384}$ which would have amended ERISA to provide opportunities for employers to set up voluntary group purchasing "association health plans" (AHPs). ${ }^{385}$ More specifically, the bill provided for preemption of state laws for fully insured, or "certified," AHPs formed by employers. ${ }^{386}$ To be certified, AHPs would have been required to provide the plan's beneficiaries and their dependents the choice of at least one option of fully insured "health insurance coverage" offered by a health insurance issuer. ${ }^{387}$ These certified plans would have been required to follow pre-existing-condition, portability, nondiscrimination, special-enrollment, and renewability rules that the Health Insurance Portability and Accountability $\mathrm{Act}^{388}$ has added to ERISA. ${ }^{389}$ In addition, the bill specified requirements regarding the

381. See Alson R. Martin \& Gregory B. Kuhn, MEWAs: An Exception to ERISA Preemption; Why, What and When, C724 ALI-ABA 363, 365 (1992), available in Westlaw, ALI-ABA database.

382. See id.

383. States have made limited efforts to allow businesses to join together to contract directly with providers. See, e.g., Colorado Initiative Moves Forward with Health Purchasing Cooperative, 3 Health Care Pol'y Rep. (BNA) 15 (Apr. 10, 1995); Minnesota Law Permits Cooperatives to Contract with Self-Insured Firms, 3 Health Care Poly Rep. (BNA) 1341 (Aug. 21, 1995).

384. See H.R. 1515, 105th Cong. (1997). S. 729 was the equivalent bill introduced by Senator Hutchinson. The bill had been well received: As of July 29, 1998, it had 161 cosponsors-25 Democrats and 136 Republicans. See Bill Tracking Service H.R. 1515, available in LEXIS, Legis Library, Bltrck File.

385. See H.R. 1515 sec. $2(\mathrm{a})$, § 801.

386. See id. § 2(b). Fully insured AHPs are known as "certified" plans on the basis of certification approval by the Secretary of Labor. See id. sec. 2(a), § 802(e). This certification proposal is quite similar to one proposed by Representative Thomas Petri in H.R. 2773, 102nd Cong. (1991).

387. See H.R. 1515 sec. 2(a), § 802(a)(2).

388; See Pub. L. No. 104-191, 110 Stat. 1936 (1996).

389. See id. at $\$ 101(\mathrm{a})$-(g) (enacting new ERISA sections 701-707, 29 U.S.C.A. $\$ \S 1181$ 1187 (West Supp. 1998) and amending ERISA at 29 U.S.C.A. $\$ \S 1003,1021,1022,1024,1132$, 1136, and 1144 (West. Supp. 1998)). 
sponsors of the $\mathrm{AHP}^{390}$ the board of trustees overseeing the plan (including fiscal and financial control), ${ }^{391}$ and the relationships between employers $^{392}$ and AHP contractors. ${ }^{393}$ Other nondiscrimination, ${ }^{394}$ fiduciary ${ }^{395}$ financial, ${ }^{396}$ reporting, ${ }^{397}$ and plan-termination ${ }^{398}$ standards were mandated for consumer-protection purposes.

AHPs could have offered non-fully-insured benefits, but these plans would have been subject to reserve, ${ }^{399}$ stop-loss insurance, ${ }^{400}$ and solvency indemnification ${ }^{401}$ requirements. The bill also provided for new criminal and civil sanctions for fraudulent activities.$^{402}$ Formation and participation in AHPs would have been voluntary. However, if employers sponsored a plan, they would have been required to offer coverage to all employees, ${ }^{403}$ and coverage could not have been subject to limitations or exclusions based on an employee's health status, ${ }^{404}$ the claims experience of the employer, ${ }^{405}$ or the level of risk inherent in the employer's business. ${ }^{406}$

There was some opposition to the bill. Although acknowledging that premiums would be reduced, ${ }^{407}$ Citizen Action, the National Association of Insurance Commissioners, and insurance company representatives suggested that the bill's major weakness was that it would have reduced state consumer protections against the problems experienced by MEWAs. ${ }^{403}$ However, their concern may have been specious. Although similar in some respects to the original MEWAs, which were largely un-

390. See H.R. 1515 sec. 2(a), \$ 803(a).

391. See id. $\$ 803$ (b)(1).

392. See id. $\$ 803(\mathrm{~b})(2)$.

393. See id. $\$ 803(\mathrm{~b})(3)$.

394. See id. $\$ \S 804(\mathrm{~d}), 805(\mathrm{a})(2)$.

395. See id. $\$ \S 805(\mathrm{a})(1)(\mathrm{A}), 810(\mathrm{c})(1)$.

396. See id. $\S 803(\mathrm{~b})(2), 806(\mathrm{f})$.

397. See id. $\$ 807(\mathrm{e})$.

398. See id. $\S \S 808-809$.

399. See id. $\$ 806$.

400. See id. §806(a)(2)(B), (d), (e), (g).

401. See id. \& 806(a)(2)(B), (f).

402. See id. at $\S 5$.

403. See id., sec. 2(a), § 804(d).

404. See 29 U.S.C.A. $\$ 1182$ (West Supp. 1998) (codifying the Health Insurance Portability and Accountability Act, Pub. L. No. 104-191, \$101(a), 110 Stat. 1936 (1996)).

405. See H.R. 1515 sec. 2(a), $\$ 805(a)(2)(A)$.

406. See id.

407. See Critics of Fawell Association Bill Tell House Panel Its Shortcomings, 5 Health Care Pol'y Rep. (BNA) 19 (May 12, 1997). Indeed, it is estimated by business groups that, because small business owners pay approximately $30 \%$ more in premiums than larger employers and also pay another $30 \%$ more because of state mandates, their health costs are significantly higher than larger employers who can self-insure. See $i d$.

408. See id. 
regulated until $1983,{ }^{409}$ AHPs are qualitatively different because they are subject to significant financial and other regulation. Further, additional state scrutiny focuses not on suspect arrangements but instead on legitimate ones, because they are easiest to observe. ${ }^{410}$ These heightened state efforts do not appear to have reduced significantly the financial losses of these plans, so claims of improved consumer protection by state regulation appear unsubstantiated. ${ }^{411}$

The Republican Patient Protection $\mathrm{Act}^{412}$ included an approach similar to that in Representative Fawell's bill. Small businesses and selfemployed persons would be able to join together into AHPs. These AHPs would have been governed by ERISA where ERISA preempts state laws. ${ }^{413}$ Employees within AHPs would then be able collectively to purchase healthcare from "HealthMarts," nonprofit organizations formed locally that would coordinate private insurer plan offerings for AHPs. ${ }^{414}$ The Republican proposal would have also expanded the use of medical savings accounts in an effort to increase health insurance coverage. $^{415}$

Although the Fawell proposal and the Patient Protection Act did not pass the 105th Congress, allowing vulnerable employers such as small businesses to form group purchasing AHPs is still an appropriate policy approach because it would provide a financially viable alternative to the options of self-insurance, traditional insurance, or no insurance at all for their employees if those employers faced increased costs as a result of the reforms proposed by this Article. The availability of the AHP alternative would allow most employers to continue to offer healthcare coverage that, as a result of new consumer protections, incentives to avoid patient injury through elimination of the ERISA and independent contractor shields, and provisions allowing physicians to advocate for appropriate patient care, provide benefits determined by the patient's medical needs, not his or her costs. ${ }^{416}$

409. See supra note 380.

410. See Martin \& Kuhn, supra note 381, at 368. Note that non-ERISA MEWAs are known as METs (multiple employer trusts).

411. See id. at 389. Note also that MCOs, Blue Cross/Blue Shield, and other representatives of the insurance industry that opposed H.R. 1515 may be concerned about more than state consumer protections; if businesses are able to form larger purchasing arrangements, then premium prices, and thus cash flow to insurance companies, will be reduced. In the highly competitive healthcare delivery market with its razor-thin margins, additional downward pressure on premiums will make competition even tougher.

412. H.R. 4250, 105th Cong. (1997).

413. See id. $\$ 1302$.

414. See id. $\$ 2202$.

415. See id. § 3201. See also infra note 416 (discussing medical savings accounts).

416. With the growing predominance of managed care, the typical patient in the United 
States will obtain care through an MCO. However, another structure that may also reduce costs and could encompass even more individuals, including employees in small businesses, is the MSA - medical savings account. The Health Insurance Portability and Accountability Act of 1996 included an MSA demonstration project. MSAs are tax-advantaged accounts coupled with high-deductible health insurance plans. A portion of MSA contributions (which must be in cash) by the employee is deductible from gross income ( $65 \%$ of the contribution for individuals, $75 \%$ for families). See 26 U.S.C.A. $\S \S 106,220$ (West Supp. 1998). Employers who pay into an MSA for their employees may also deduct these contributions while not subjecting employees to additional tax liability. However, an employee and his or her employer may not both contribute to the employee's account in any given year. See IRS Explains Medical Savings Accounts, 58 TAX'N FOR ACCT. 102, 102 (1997).

MSAs as established by the Health Insurance Portability and Accountability Act are limited in their number, duration, and target beneficiary group. Only employers with an average of $\mathbf{5 0}$ or fewer employees that establish high-deductible health plans are eligible to participate. See 26 U.S.C.A. $\$ 220$ (c)(4) (West Supp. 1998). The duration of the demonstration project is only four years, and the program will sunset in the year 2000 . See id. $\$ 220(\mathrm{i})$. The ceiling for participants is 750,000. See id. The Republican leadership's Patient Protection Act would have abolished the ceiling, allowed all employers to offer these accounts, increased the amount of the deduction for MSAs, reduced the mandated deductible amounts, and allowed both employers and employees to contribute to them. See H.R. 4250 \$ 3201.

The basic theory behind MSAs is that when individuals spend their own resources rather than have a third party pay for their healthcare, they will be more judicious in their choices and purchases. Anecdotally, MSAs without federal tax benefits have been very popular with business and have reduced health costs considerably. See, e.g., Considering MSAs as One Health Care Option for Law Firms, 96-2 COMPENSATION \& BENEFITS FOR L. OFF. 3 (1996) (discussing advantages of MSAs for law firms, reporting on a study by the Washington Medical Savings Account Project that showed annual savings with an MSA plan of $\$ 786$ for individuals and $\$ 3,554$ for families, and noting that one insurance company's MSA plan has a $98 \%$ employee satisfaction rate); J. Patrick Rooney, Medical Savings Accounts Cut Corporate Health Care Costs, Promote Employee Wellness, HEALTHSPAN, Mar. 1994, at 13, 13-14 (reporting that Golden Rule Insurance Company's MSA program satisfies both corporate and employee interests); William V. Roth, Jr., Medical Savings Accounts, 11 J. ConTEMP. HeALTH L. \& PoL'Y 149 (1994) (detailing a statement by Senator Roth reporting highly positive experiences with MSAs of Forbes, Dominion Resources, Golden Rule Insurance Company, Quaker Oats, and Council for Affordable Health Insurance, as well as state legislation that affords MSAs favorable tax status).

Although it appears that MSAs have the potential to minimize cost increases and are favorable to both employers and employees in financing healthcare coverage, they do not fit well in the managed care world. MSA funds typically are used to pay for healthcare on the basis of discrete episodes of illness, rather than applied as a basic premium for a given level of care across multiple sickness episodes. MCOs generally do not provide high-deductible planis or payment for services based on episodes of illness; this fact limits the MSA concept to the small fee-forservice market. The paucity of MSAs established under the Health Insurance Portability and Accountability Act's demonstration program reflects this tendency. Only 7853 MSAs had been established by April 30, 1997, and only 17,145 had been established by June 30,1997. See Lisa Fagan et al., Medical Savings Accounts, in MERTENS LAW OF FED. INCOME TAX'N $\$ 7.155 .50$ \& n.63 (1997). The complexity of these products to agents and consumers may also limit the spread of MSAs. See U.S. GENERAL ACCOUNTING OFFICE, MEDICAL SAVINGS ACCOUNTS: FINDINGS FROM INSURER SURVEY, GAO/HEHS-98-57 (1998). However, as the competitive climate gets even more intense, MCOs will most likely move toward expanding available products for patients to include high-deductible policies amenable to MSAs. (Perhaps recognizing this, Representative Salmon introduced H.R. 2668, which would have eliminated the MSA demonstration project numerical limitation.) If costs continue to rise, MSAs will provide em- 


\section{CONCLUDING REMARKS}

The legal framework has changed dramatically since the fee-forservice days when patients enjoyed universal access to any provider, and physicians had no disincentives to providing a wide range of services or pursuing aggressive diagnostic and treatment techniques. The reigning ethic placed the value of human health at a high level, where any and all care for the patient was appropriate, and indeed expected, as long the tests and treatment might be beneficial. The legal system focused on the potential negligence of the medical decisionmakers, physicians, who had every diagnostic and therapeutic option available to diagnose and treat patients.

The revolution of managed care has changed this orientation. Because incentives are no longer alinged between patient, physician, and payer, significant conflicts have arisen due to the new imperatives to minimize care and thus costs. Implicitly, the value of human life has been discounted so that only care meeting some actuarial standard may be approved and paid for. As a result, patient interests conflict with those of their physicians and payers, and physician interests are in conflict with those of payers and patients. The tripartite relationship of patient-MCOphysician has become the norm, and the decisionmaking process for care has changed fundamentally.

The legal system has intensified the conflicts between the parties through a concatenation of circumstances. ERISA provides one party, the $\mathrm{MCO}$, with tremendous protection against liability for adverse medical decisionmaking results. The common law of tort furthers that protection, and the common law of contract assures that physicians will cooperate with the MCO's cost-containment objectives. Yet although legal norms have resulted in significant protections for MCOs, intentionally or unintentionally, no corresponding norms have emerged to protect the patient and physician. Their relationship is assumed to be the same as in the days of fee-for-service medicine. In reality, financial pressures, market changes, and the encouragement of managed care have altered when, where, and how these two parties will interact.

While it may be easy to blame MCOs for their actions or activities, all parties are culpable. Governments, employers, and employees wish to minimize their costs to maximize their interests and incomes. Physicians and patients have abused the fee-for-service system and still longingly look to the "blank check" philosophy in healthcare, even though costs

ployers and employees another option to forgoing healthcare insurance altogether. These options may also be offered to Medicare beneficiaries on a permanent basis rather than on the demonstration-project basis passed in 1997. See Pub. L. No. 105-33, 111 Stat. 251, 270-360 (1997) (describing a Medicare MSA demonstration project that would allow 390,000 beneficiaries to enroll in a pilot project beginning in 1999 and ending in 2003). 
continue to rise. ${ }^{417}$ Because there is a significant tradeoff between costs and care-patient injury-the legal system must update its passive and antiquated worldview so it can recognize the conflicts in modern healthcare and act to align incentives to minimize patient injury.

Indeed, now that "easy" managed care savings have been accomplished, ${ }^{418}$ reforms must be made, or financial pressures and incentives will drive care below medically appropriate levels, if they have not yet done so. In addition, these reforms are necessary because they can be beneficial for all parties in the intensely competitive health delivery market. The reforms posited here will protect patients from the incentive of MCOs to simply limit costs with little attention to care; remove substantial doubt that physicians have splintered alliances; and allow patients to make substantive assessments of an MCO's care philosophy through an analysis of the reasons for hiring and firing medical providers as well as the level of the MCO's participation and leadership in patient injury research. These proposals will allow physicians to do what they do bestdiagnose, treat, and advocate for patients on a foundation of trustrather than force them to work under a conflicting set of incentives to provide or limit care, insure patients, and assess their risks of injury. These changes will allow employers to evaluate MCOs on the basis of substantive competitive characteristics--treatment outcomes, preventive care, and chronic disease management-rather than solely on costs, which may or may not reflect an adequate level of care. ${ }^{419}$ The legislation

417. Reversion to the fee-for-service days will not occur. "I know, and all the world knows, that revolutions never go backward." William Seward, Speech at Rochester, Oct. 1858, in OXFORD DICTIONARY OF QUOTATIONS 563 (4th ed. 1992).

418. "The years of easy savings achieved simply by moving consumers from fee-for-service to managed care are history..."." Julie A. Jacob, Managed Care Strives to Recover from '97 Struggles, AM. MED. NEws, Jan. 12, 1998, at 1, 1. In addition, MCOs in Minnesota-a mature managed care market that is a bellweather for other plans and markets across the countryhave taken significant losses due to intense competition. In 1996, most of the MCOs in the state lost money; many also lost money in 1995 on managed care operations. See Mark Wolski, Minnesota HMOs Suffer Worst Year; Eyes on Growing Self-Funded Plans, 4 Managed Care Rep. (BNA) 11, 11 (Jan 7, 1998); see also Report Predicts Rocky Industry Future Despite Continued Short-Term Growth, 6 Health Care Pol'y Rep. (BNA) 281, 282 (Feb. 9, 1998) (reporting continued negative margins for MCOs in metropolitan markets); Emily Roskey, Study Finds Steady HMO Growth, Declining Operating Margins, 4 Managed Care Rep. (BNA) 104 (Feb. 4, 1998) (same). Indeed, other mature market states such as California are also experiencing difficulties. See Scott Falk, Rising Medical Costs May Mean Another 'Bleak' Year for HMO Profits, 3 Managed Care Rep. (BNA) 1120 (Dec. 3, 1997).

419. Some companies are starting to form quality initiatives, which have substantive benefits for choosing the appropriate healthcare organization but also allow businesses to reduce healthcare costs in the long term and attract and retain desirable employees. See Various Initiatives in Place at Large Corporations, Survey Finds, 5 Health Care Pol'y Rep. (BNA) 1878 (Dec. $15,1997)$. It is encouraging to note that large corporations, and hence large purchasers of healthcare, such as General Motors, GTE, International Paper, J.C. Penny, and Merck are engaged in these quality initiative efforts. See id. Nonprofit health plans such as Kaiser Perma- 
proposed would allow MCOs that provide the best product-healthcare management and services-to succeed rather than forcing these organizations to compete with MCOs that simply are able charge lower prices for substandard care due to insulation from liability and a brazen attitude toward patient care and safety.

Finally, by providing all players in the healthcare arena with aligned incentives to render the best care possible for the patient, efforts to minimize patient injury can be coordinated. In a system where safe, efficient, and effective care is a competitive advantage, MCOs would have an incentive to engage in innovative injury-reducing efforts; physicians would be able to join in such efforts and contribute their clinical expertise; and patients would be able to choose the MCOs that effectively lead the research and implementation efforts.

Until the currently distorted incentives and the legal framework on which they are based are addressed, however, there will continue to be an emphasis on providing simply cheaper care in the U.S. healthcare delivery system, rather than medically appropriate, patient-centered care. And the costs of this philosophy will not be realized until it is too latewhen the patient has already been injured, and all the money in the world cannot restore his or her health.

nente, HIP Health Insurance Plan, and Group Health Cooperative of Puget Sound are also interested in competing on the basis of national standards that are legally enforceable; this competition would allow these nonprofit plans to compete on quality issues rather than merely price. These MCOs have joined forces with other healthcare providers and consumer groups to call for such competition. See Robert Pear, 3 Big Health Plans Join in Call for National Standards, N.Y. TIMES, Sept. 25, 1997, at A28. In addition, it appears that employers are beginning to realize that simply focusing on healthcare costs negatively impacts the quality of care. See Employers Say Health Cost Pressures Hurting Quality of Care, Survey Finds, 6 Health Care Pol'y Rep. (BNA) 435 (March 9, 1998). However, although nonprofit MCOs, patient groups, providers, and employers have all recognized this concern, President Clinton's advisory panel has neither adopted national standards nor addressed the critical issues of ERISA, independent contractors, and deselection. See Gwen Moulton, Advisory Panel Tentatively Approves Report to President, Stalls on ERISA, 4 Managed Care Rep. (BNA) 216 (Mar. 4, 1998). 
